MUNICIPAL ORGANIC SOLID WASTE MANAGEMENT AND PROGRAM

SUSTAINABILITY: A STUDY OF THE REGION OF PEEL'S GREEN BIN PROGRAM

by

Nathalie Zonta, B.E.S., York University, Toronto, ON, June 2014

A thesis
presented to Ryerson University
in partial fulfillment of the
requirements
for the degree of
Master of Applied Science
in the Program of Environmental Applied Science and Management

Toronto, Ontario, Canada, 2016

(C) Nathalie Zonta 2016 


\section{AUTHOR'S DECLARATION}

I hereby declare that I am the sole author of this thesis. This is a true copy of the thesis, including any required final revisions, as accepted by my examiners.

I authorize Ryerson University to lend this thesis to other institutions or individuals for the purpose of scholarly research.

I further authorize Ryerson University to reproduce this thesis by photocopying or by other means, in total or in part, at the request of other institutions or individuals for the purpose of scholarly research.

I understand that my thesis may be made electronically available to the public. 


\title{
MUNICIPAL ORGANIC SOLID WASTE MANAGEMENT AND PROGRAM SUSTAINABILITY: A STUDY OF THE REGION OF PEEL'S GREEN BIN PROGRAM
}

\author{
Nathalie Zonta \\ Master of Applied Science, 2016 \\ Environmental Applied Science and Management, Ryerson University
}

\begin{abstract}
The diversion of municipal organics to manufacture compost is increasingly seen as a proactive alternative to waste management. This study examines the sustainability of Region of Peel's (ROP) Green Bin program through the lens of the Three Spheres of Sustainability: environment, economic and social. This model was used to establish the Sustainability Criteria which ask a total of 27 questions concerning the program's sustainability. To answer these questions, a literature review was conducted in addition to in-person interviews with two groups of farmers: one with experience using municipal compost and one without. The results indicated that the program is sustainable when the Deep Ecology and Strong Sustainability model is applied. Further, it was concluded that the environmental sphere plays a paramount role by limiting the social and economic spheres to its environmental carrying capacity. Practically speaking, composting is worthwhile even when faced with limited revenue and public misconceptions about compost.
\end{abstract}




\section{Acknowledgements}

I would to thank my thesis supervisor, Dr. Paul Missios for his unwavering support and professional guidance throughout the research process. From encouraging me to re-think my thesis proposal to the final thesis defence; Dr. Missios's calm and reassuring leadership had been a source of strength.

I would like to thank the defence committee: Dr. Searcy, Dr. Pushchak and Dr. Atkinson for showing interest in my research and dedicating their time and their knowledge to provide feedback towards the improvement of my thesis.

Finally, I would like to my mother, Erika Zonta, my Editor and Chief for challenging me to examine issues from multiple perspectives, to triple check the facts, and to insist that I make connections and provide evidence for my assertions. 


\section{Table of Contents}

Title page

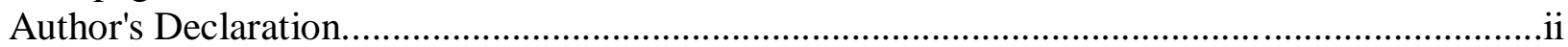

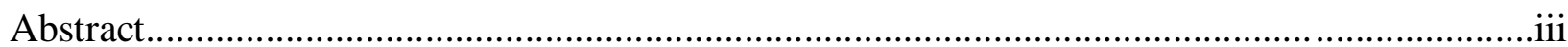

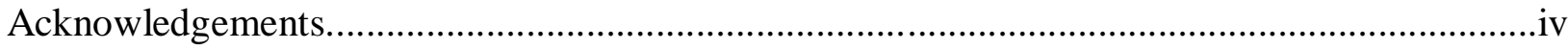

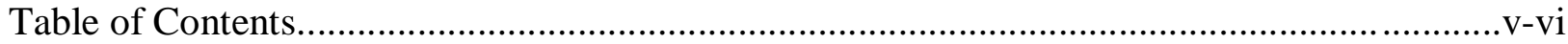

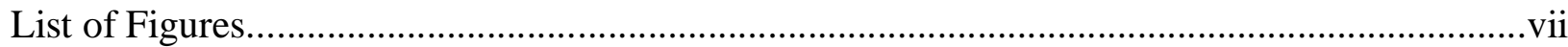

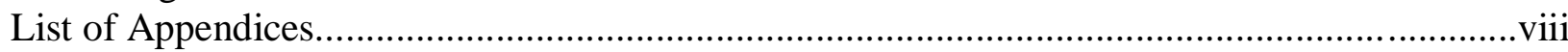

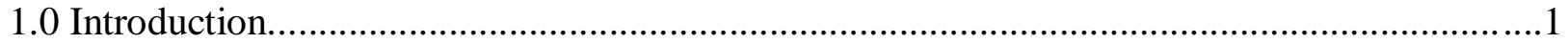

1.1 The Evolution of Landfills and the Movement Towards Waste Diversion..................2

1.2 Waste Management Practices in Canada............................................................. 3

1.2.1 Waste Management Practices in the Region of Peel...................................4

1.2.2 The Green Bin Agriculture Test as a Future Direction.................................5

1.3 Demographics of the Region of Peel.................................................................6

1.3.1 Farmer Demographics in the Region of Peel...........................................

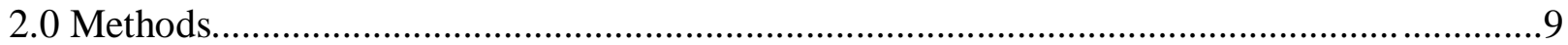

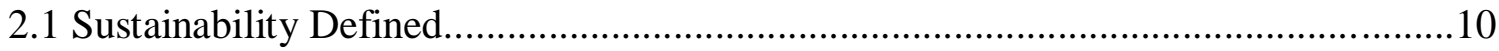

2.2 The Sustainability Criteria, Categories and Measures............................................13

2.3 In-Person Interviews with "Participating" and "Non-Participating" Farmers.............17

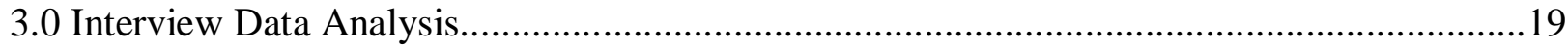

3.1 Participating and Non-participating Farmer Interview Data...............................20

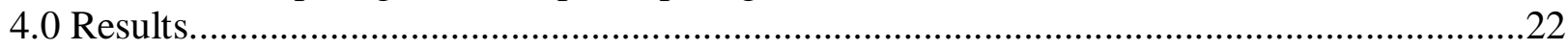

4.1 Environmental Category of Sustainability.......................................................22

4.1.1 Environmental Criterion: Is the Organic Waste Being Repurposed?.........23

Environmental Measure i.................................................................24

Environmental Measure ii...............................................................25

Environmental Measure iii...........................................................28

4.1.2 Environmental Criterion: Is the Compost Free of Harmful Chemicals?.....29

Environmental Measure i................................................................ 30

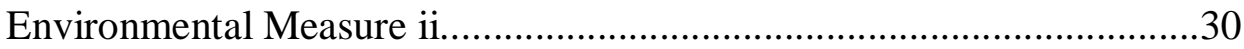

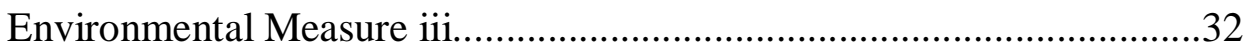

4.1.3 Environmental Criterion: Are Environmental Externalities Limited?.........34

Environmental Measure i................................................................34

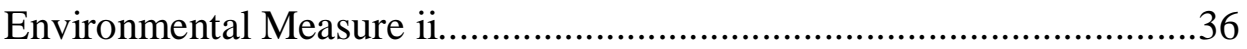

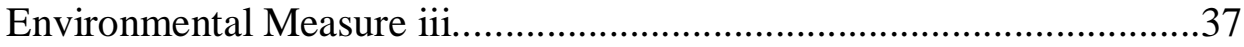

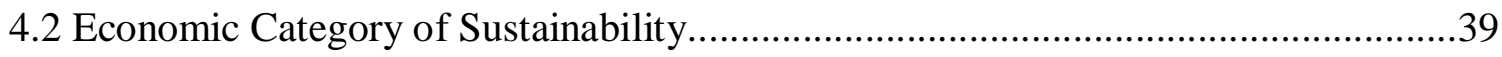

4.2.1 Economic Criterion: Is There Interest By Farmers?................................41

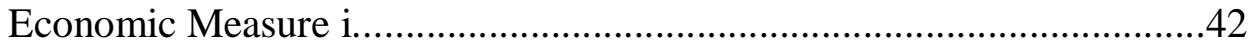

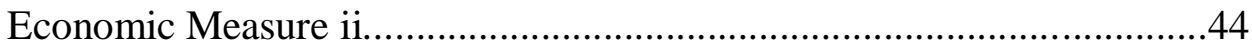

Economic Measure iii....................................................................45

4.2.2 Economic Criterion: Does It Make Sense for the Farmers to Buy

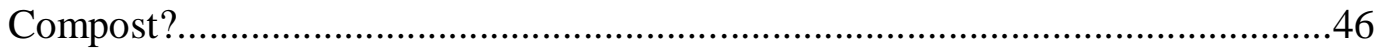

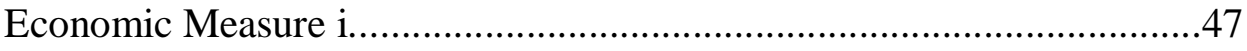

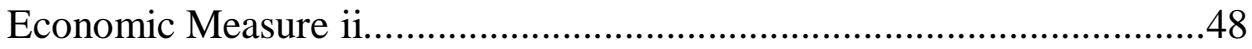


Economic Measure iii.......................................................................49

4.2.3 Economic Criterion: Is There Enough Supply and Demand?.....................50

Economic Measure i.........................................................................51

Economic Measure ii................................................................55

Economic Measure iii......................................................................5

4.3 Social Category of Sustainability....................................................................54

4.3.1 Social Criterion: Do All Residents Have Equal Access to the Green Bin

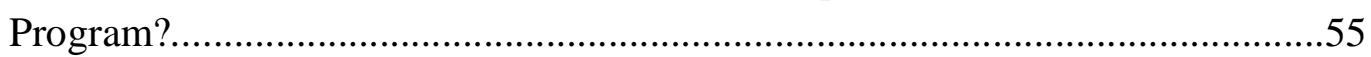

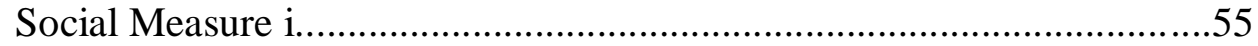

Social Measure ii........................................................................5

Social Measure iii..........................................................................57

4.3.2 Social Criterion: Is the Compost Equitably Priced?...............................59

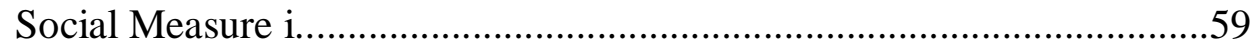

Social Measure ii...........................................................................60

Social Measure iii...........................................................................61

4.3.3 Social Criterion: Is There a Public Awareness/Educational Campaign

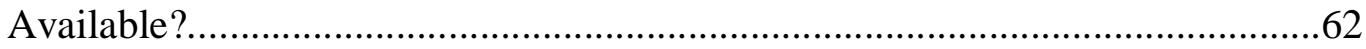

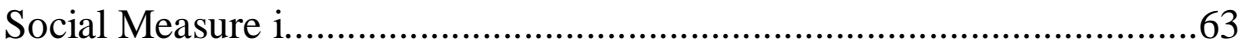

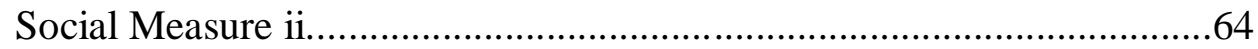

Social Measure iii.....................................................................65

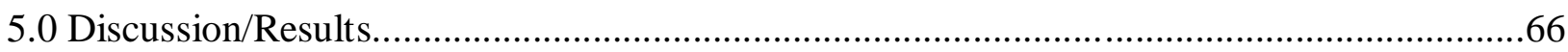

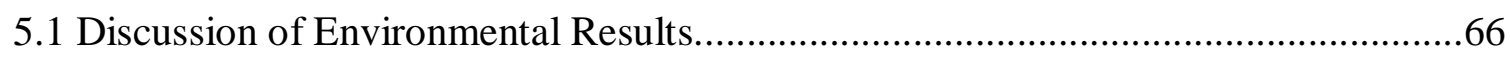

5.2 Discussion of Economic Results.....................................................................6

5.3 Discussion of Social Results....................................................................... 71

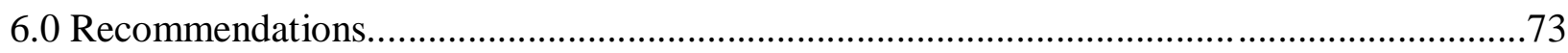

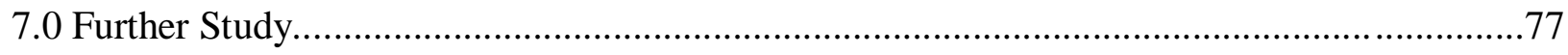

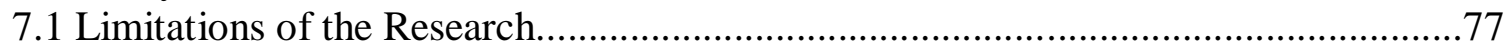

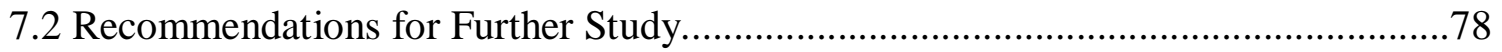

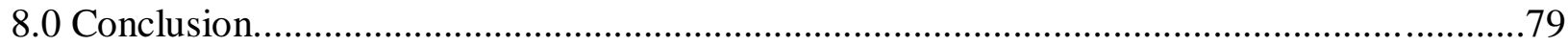

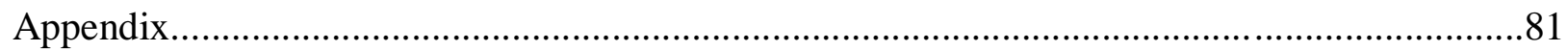

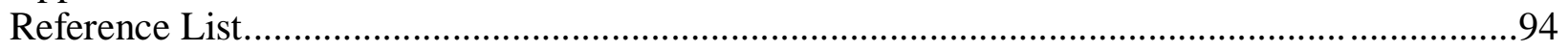




\section{List of Figures}

Figure 1: Region of Peel (ROP) Map...............................................................................

Figure 2: Farms Classified by Industry Group in Peel 2011...................................................9

Figure 3: Deep Ecology and Strong Sustainability Versus The Three Spheres of

Sustainability 10

Figure 4: Green Bin Program Sustainability Criteria............................................................13-15

Figure 5: Participating" and "Non-Participating" Farmer Interview Question Breakdown...........18

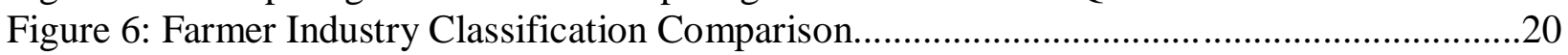

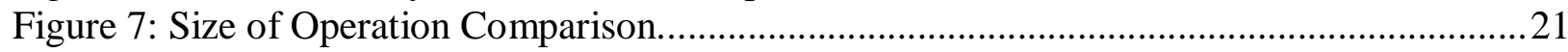

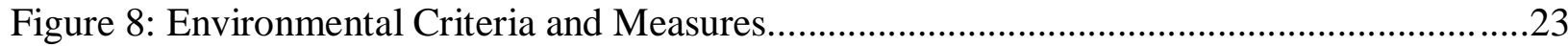

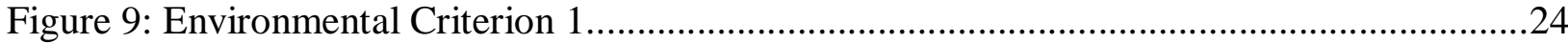

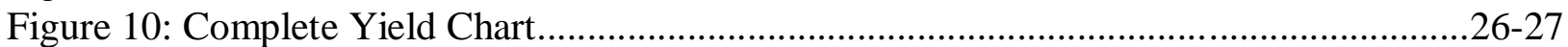

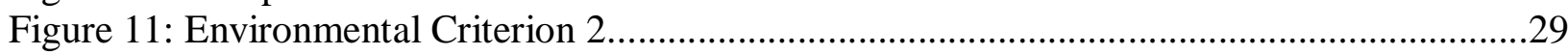

Figure 12: Environmental Criterion 3 ………………….................................................

Figure 13: Economic Criteria and Measures..........................................................................

Figure 14: Economic Criterion 1.......................................................................................

Figure 15: Primary Soil Amendment Used by "Non-Participating" Farmers................................42

Figure 16: Economic Criterion 2.........................................................................................4

Figure 17: 2013 Compost on Corn - Winchester Research Farm................................................49

Figure 18: Compost on Forages (Region of Peel Compost).......................................................50

Figure 19: Economic Criterion 3 ...................................................................................

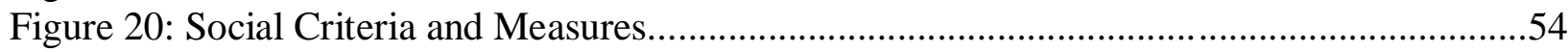

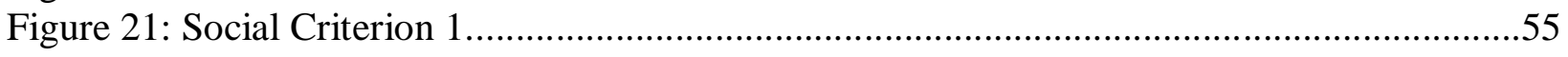

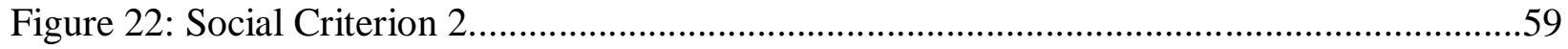

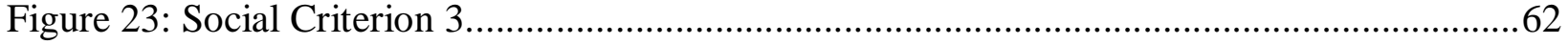




\section{List of Appendices}

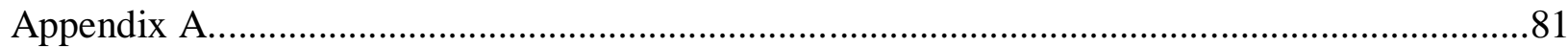

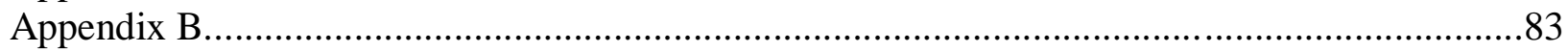

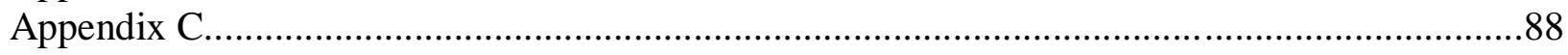

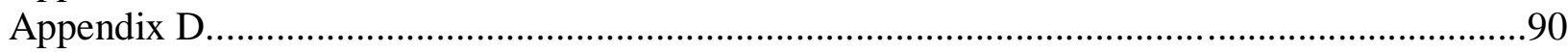

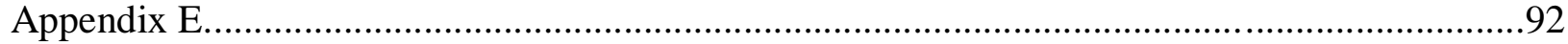

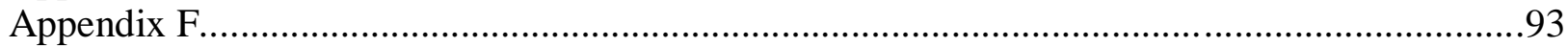




\subsection{INTRODUCTION}

Achieving sustainability in waste management appears to be an unattainable goal as the population continuously grows and the amount of garbage created exponentially increases. The incorporation of waste diversion into the waste management tool kit provides a means to reduce the amount of waste headed for the landfill. However, the long term sustainability of this method

of dealing with waste can still be called into question. The objective of this study is to determine the sustainability of the Region of Peel's (ROP) Green Bin collection program as an alternate method to deal with organic waste. Over the course of the study, the terms "Municipal Solid Waste Management", "Green Bin program", "sustainability", and "Region of Peel" will be prevalent and necessary for the reader to understand as they relate to waste management. Most notably, Solid Waste Management (SWM) is a discipline having to do with the control of waste from generation to disposal (Tchobanoglous et al., 1993, p. 7). This must be achieved in a manner that is consistent with the best principles of public health, conservation, engineering, economics and aesthetics while taking public attitudes into consideration (p. 7). In particular, the organic SWM programs for food waste and yard waste which are implemented by municipalities will be the focus of the study. The Green Bin program refers specifically to the food waste and yard waste collection program overseen by the ROP to manage the organic waste that residents need to dispose of (Region of Peel, 2015b). For the purposes of this study, sustainability refers to the success of the waste management program when taking into consideration the environmental, economic and social facets of the program (World Commission on Environment and Development, 1987). The Three Spheres of Sustainability theoretical model will provide multiple lenses to analyze the sustainability of the Green Bin program from the perspective of the environment, economy and society. Criteria based on this theoretical model were established which will be used to analyze the ongoing success of the Green Bin program in achieving sustainability and make recommendations for improvement. Last, the ROP is a regional municipality located in Southern Ontario that encompasses the municipalities of Brampton, Caledon and Mississauga (Statistics Canada, 2015). 


\subsection{The Evolution of Landfills and the Movement Towards Waste Diversion}

The first garbage collection service relied on horse-drawn carts to transport waste both within the community and outside to an open pit for dumping (Tammemagi, 1999, p. 20). This system was established by the Roman Empire and required households to toss refuse into the streets for collection (p. 20). However, by the 1500s Europe had begun to experience garbage problems due to the concentrated population in cities (p. 20). North America which had a smaller population density and less industrialisation did not begin to experience these problems until the turn of the 20th Century (p. 22). Landfilling was the most popular method of waste disposal in the United States of America (USA) due to the low cost of land and inexpensive technology (p. 23). Other systems in practice at this time included water and ocean disposal systems and incineration (p. 22). Incineration which also had its roots in antiquity was implemented mainly to reduce the volume of waste entering landfills (Neal \& Schubel, 1987, p. 4). Nevertheless, the wide scale use only continued until the 1950 s, when regulations were put in place to limit burning in open dumps and by simple incinerators (p. 4). The incinerators' smell and notable plumes of polluted air travelling back to communities had resulted in concerns being voiced by residents (p. 4). Other waste management practices would receive similar negative feedback from the population in the coming years.

Indeed, landfills were considered a public nuisance and health hazard due to concerns about vermin, windblown litter, odours, and fires (Tammemagi, 1999, p. 26). In the mid-1900s there was very little technology involved in the landfilling process as landfills were little more than open pits (p. 23). That changed with the development of sanitary landfills which spread the waste into thin layers and compacted it before placing a layer of soil over it at the end of the day (Stone, 1976, p. 236-237). This solution only temporarily satiated public opposition as new concerns arose in the 1970s and 80s over ground water contamination (Tammemagi, 1997, p. 27). A number of technological improvements for landfill designs followed to limit the threat to groundwater including bottom liners made of clay or synthetic materials, caps to decrease infiltration, collection systems to capture leachate and gas, and landfill monitoring (p. 27). Regardless, landfill leachate remained a concern (p. 27). The incorporation of site selection criteria for landfills helped the situation somewhat (p. 29). However, community and neighbourhood group lobbying against the construction of landfills resulted in increasingly more 
rigid criteria (pp. 29-30). By the end of the 1980s, the fact that many landfill sites were reaching their full capacity further complicated the matter and made new sites not only difficult to identify but impossible to secure (Neal \& Schubel, 1987, p. 4).

Fortunately, since the mid-1980s, there was a rapid increase in the availability of recycling and composting programs (Tammemagi, 1997, p. 252). Use of the "three Rs" (reduce, reuse and recycle) ensured that the amount of waste that needed to be disposed of was minimized, therefore reducing our need for landfills (p. 247). These programs also helped decrease our demand for energy, lessen pollution on land, water and air, and ultimately conserve valuable raw materials (p. 247). Today, most communities in North America have access to curbside recycling, including multiple-stream recycling programs that incorporate yard waste, household organic waste, composting, and recycling (Ferrara \& Missios, 2005, pp. 221-222). Meanwhile, some communities are experimenting with bag limits and "pay as you throw" systems which have the benefit of reducing waste production in an effort to lower garbage collection costs or prevent the over-production of waste (p. 222). Nonetheless, the good intentions of recycling policy may not be reflected in community recycling behaviour, and though "pay as you throw" results in a significant increase in recycling intensity, the condition of free bags per collection negate the positive effects (p. 235). Similarly, bag limits were not seen to increase recycling intensity and may even decrease the recycling of certain materials (p. 236). Evidently, there are several monetary factors impacting recycling behaviour, but on the other hand, a number of non-monetary factors may influence recycling attitudes as well, such as social norms and convenience (Koford et al., 2012, p. 747). To conclude, while recycling programs are becoming more adapted to the needs of the community and their environment, landfills have failed repeatedly to evolve.

\subsection{Waste Management Practices in Canada}

In Canada, Municipal Solid Waste (MSW) is regulated by the provinces and territories (Canadian Council of Ministers of Environment, 2014a, p. 3). However, it is the municipal or regional authorities that ultimately manage the MSW or the waste management industries under contract with them (p. 3). Accordingly, the local governments must adhere to regulations established by the provinces and territories on siting, licensing, and monitoring for waste 
disposal facilities (Sawell et al., 1997, p. 351). The federal government is involved only in federally owned facilities responsible for inter-provincial and inter-national transport (p. 351). Moreover, territories that have yet to delegate tasks are also the responsibility of the federal government (Canadian Council of Ministers of Environment, 2014a, p. 3). Nevertheless, the federal government does not act as a centralized regulatory authority for waste management (Sawell et al., 1997, p. 351).

In its place, the Canadian Council of Ministers of the Environment (CCME) established in the 1980s acted to unify national action and develop guidelines and standards for specific environmental issues (p. 351). Committees were created that consisted of representatives from the federal and provincial levels of government in order to develop policies to draft into provincial legislation (p. 351). With regard to waste in particular, the CCME intended to develop tools and best practices to reduce waste disposal from the Institutional, Commercial and Industrial (ICI) sectors, the Construction, Renovations and Demotion (CRD) sectors, and the organic waste sector (Canadian Council of Ministers of Environment, 2014b). In the future, it is expected that indicators for progress will be identified, collaborations with business, government, municipal and community partners will continue and advances will be made on the Canada Wide Action Plan for Extended Producer Responsibility (CAP-EPR) (2014b). EPR is an approach to environmental policy that shifts the responsibility for products after the consumer stage in the product's life cycle to the original producer of the product (Canadian Council of Ministers of Environment, 2014c). CAP-EPR was approved in Canada in 2009 in addition to the Canada Wide Strategy for Sustainable Packaging (2014c). Currently, the focus is on gathering information on the management of construction, renovation, and demolition waste (2014c).

\subsubsection{Waste Management Practices in the Region of Peel}

In the ROP, the Long Term Waste Management Strategy was approved in 1997 and then renamed in 1999 as the Long Term Waste Resource Management Strategy (LTWRMS) (Region of Peel, 2015a). At its core, the strategy is based on the 4Rs of the Waste Management Hierarchy: Reduce, Reuse, Recycle and Recover (2015a). Therefore, the objectives of the strategy are tied to the 4 Rs philosophy starting with the first objective about the design of waste management services meeting the needs of the customer in a cost effective way (2015a). To meet this objective, the ROP has outlined a number of actions it will take, including regularly 
reviewing the program, being aware of best practises, and investing in long-term infrastructure (2015a). A second objective is to reduce the negative impact of waste, which is accomplished by implementing a Waste Reduction Plan, increasing focus on reuse, and collaborating with the packaging, product, retail, and food industries to reduce waste (2015a).

The ROP provides curbside pickup of grey bins, blue bins and green bins for residential households (Region of Peel, 2015b). After a year-long pilot project, the ROP implemented a cart-based, bi-weekly collection program for garbage, recycling and organics starting January $4^{\text {th }}$, 2016 (2015b). Three new carts including garbage, recycling and organics carts in addition to a new kitchen container were delivered free of charge to residents (2015b). Benefits for communities include the carts being easier to manoeuvre, pest resistant and more efficient in keeping the neighbourhood clean (2015b). Meanwhile the ROP benefits from cost-savings, reductions in waste and Greenhouse Gas (GHG) emissions, and fewer worker injuries (2015b). The organics and yard waste that are collected during curb-side collection are converted into compost by the ROP (Region of Peel, 2015c).

In addition, the ROP operates six Community Recycling Centres (CRCs) which are disposal centres for waste, recyclable materials, and Household Hazardous Waste (HHW) (Region of Peel, 2015d). Two CRCs are located in Brampton, two in Caledon and two in Mississauga (2015d). At these sites, a number of items can be dropped off by the residents free of charge, like blue bin recyclables, scrap metal, and tires to name a few (2015d). Each CRC operates a Re-Usable Goods Drop-Off Area where unwanted items in reasonable working condition are dropped off and salvaged by interested individuals (2015d). A standard per kilogram rate applies to carpet, construction material, and drywall (2015d).

\subsubsection{The Green Bin Agriculture Test as a Future Direction}

The Green Bin Agriculture Test is a pilot project by the ROP that attempts to divert organic waste from landfills through partnerships with local farmers. As a part of the project, the ROP is responsible for sorting and curing the organic waste collected from Green Bins. The resulting compost is then sold at \$5-7 per tonne to farmers (Brown, 2014, p. 32). The farmers are expected to cover the cost of transporting the compost which varies with distance and the cost of spreading which amounts to \$3-5 per tonne (p. 32). Farmers participating in the project may also save carbon credits for emissions trading from the replacement of chemical fertilizers with the 
ROP's compost. Although, the carbon credits system is not in effect at the time of print, if it becomes instated in the future, farmers who are using compost would save credits, while farmers who are using fertilizer would have to buy credits. This exchange occurs due to the high levels of carbon dioxide $\left(\mathrm{CO}_{2}\right)$ generated in the production of chemical fertilizer thus contributing to GHG emissions and climate change.

At its core, the goal/objective of the project is to determine how to divert more organic waste from landfills and to learn about compostable materials (Criscione, 2015). By testmarketing the compost with the Green Bin Agriculture Test, the ROP hopes to verify the longterm effect of compost use in addition to the benefits for agriculture (Region of Peel, 2015e). Changes in soil chemistry and crop productivity will be carefully evaluated in addition to environmental, social and economic impacts (Criscione, 2015). A successful trial will help municipalities and compost producers find more markets for their compost and help farmers with soil health and crop production (Region of Peel, 2015e). The project is headed by Larry Conrad, Manager Waste Operations, Waste Management Division at the ROP and is currently in its fourth trial year of five (L. Conrad, personal communication, October 15, 2015).

The Green Bin Agriculture Test is funded by the Green Municipal Fund (GMF) which provides capital to exemplary plans, studies and projects in the fields of waste, water, energy, transportation and brownfields (Federation of Canadian Municipalities, 2014). However, initiatives considered for the GMF must attain a significant environmental impact and must be replicable in other potential communities (2014). An article in the Brampton Guardian by Criscione (2015) recently announced that the ROP will receive additional $\$ 131,150$ from the GMF in grant money. The money is intended for a study on compostable materials as a supplement to traditional fertilizers which is taking place on 14 Ontario farms (2015).

\subsection{Demographics of the Region of Peel}

The ROP is a municipality located in Southern Ontario that is a part of the Greater Toronto Area (GTA) and the Golden Horseshoe (Region of Peel, 2015f). In total, the ROP has a population of 1.4 million (2015f). With a total land area of 1,246.89 square kilometres, the ROP has a density of 1,040.0 people per square kilometre (Statistics Canada, 2015). Notably, this number represents an average and the true density of a given area is expected to vary greatly 
between low density towns and high density cities. In particular, the ROP encompasses the Town of Caledon, the City of Brampton and the City of Mississauga as seen in Figure 1: Region of Peel (ROP) Map, below (2015f).

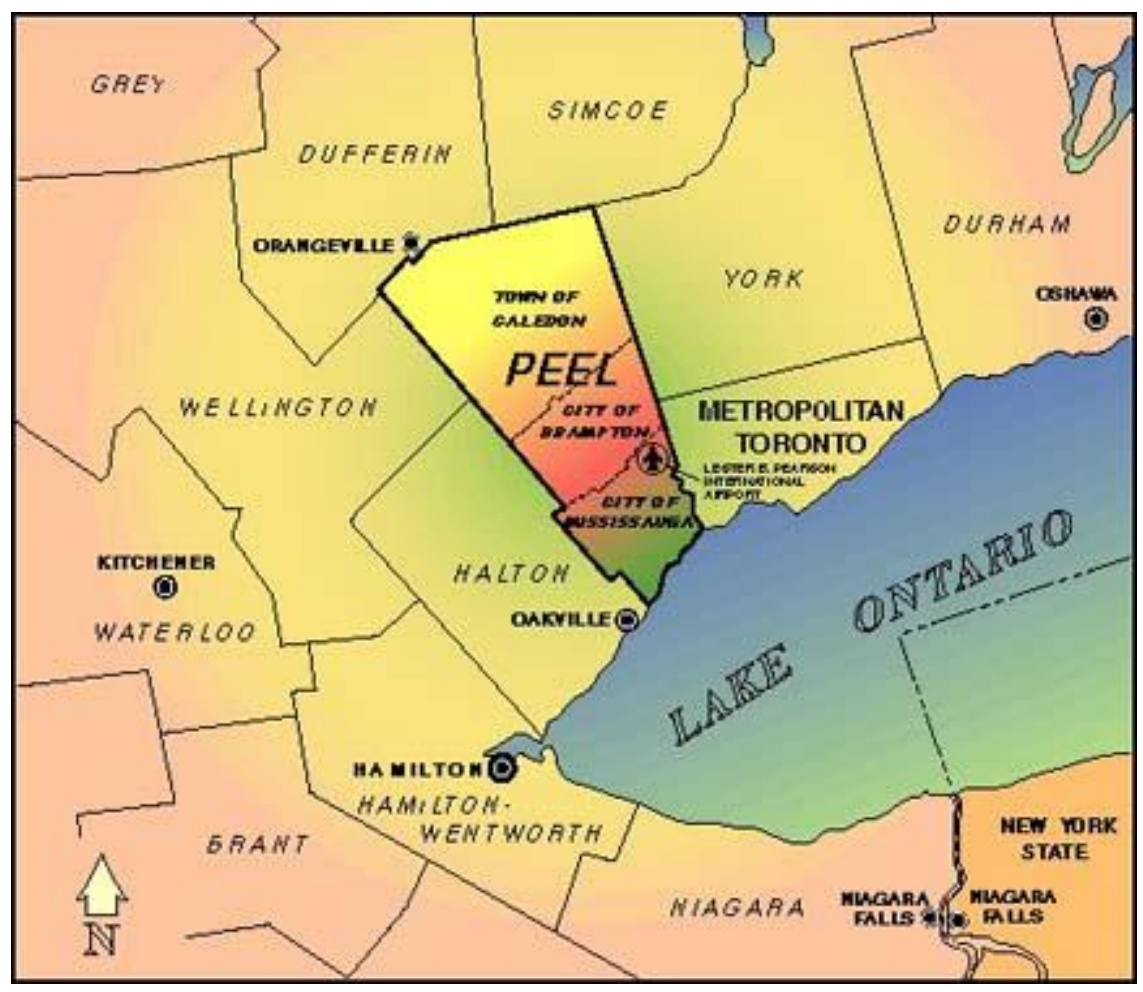

Figure 1: Region of Peel (ROP) Map (Region of Peel, 2015f).

The Town of Caledon which is located the furthest North, has a population of 58,000 people and an area of 700 square kilometres (Town of Caledon, n.d.). It is close to large urban centres and transportation routes (n.d.) and has a number of ecologically significant areas, such as the Forks of the Credit River. The City of Brampton, located below the Town of Caledon, has a population of over 600,000 and is one of Canada's largest and fastest growing cities (City of Brampton, 2015). It is called "Canada's Flower City" and is known for its beautiful floral displays and natural retreats (2015). Lastly, the City of Mississauga spreads North bound from Lake Ontario and is located the Southernmost in the ROP. It has a population of 729,000 residents and is Canada's sixth largest and fastest growing major city (Mississauga, 2015). Mississauga has also been named Canada's safest city for eight years in a row and is a corporate capital with almost 55,000 registered businesses (2015). 


\subsubsection{Farmer Demographics in the Region of Peel}

The 2011 Census of Agriculture Farm and Food Operator Data was released for the ROP and the GTA in 2011 with a summarizing bulletin in 2013 (Ontario Ministry of Agriculture, Food and Rural Affairs, 2014; Peel Data Centre, 2013, p.1). In the ROP, 30\% of the total land was used for agriculture in 2011 (p.1). More specifically, the ROP had 440 census farms and 660 farm operators in 2011 (p. 1). In the decade from 2001 to 2011, the number of farms in the ROP decreased by $16 \%$ (p. 2). In the same time period, the population of the ROP increased from $1,032,000$ people to $1,350,097$ which is a rise of $30.82 \%$ (Peel Data Centre, n.d.). The population is projected to continue growing according to the Places to Grow Act which forecasts an increase to 1.64 million by 2031 (Region of Peel, n.d. b). With the rise in population and the continuous demand for single family housing, developers are buying up agricultural land in areas that are zoned for development at premium prices. In fact, in the ROP the amount of agricultural land decreased from 115,352 acres in 1991 to 93, 843 acres in 2011 which constitutes a 22\% decrease (OMAFRA, 2014). Further, there was a 7\% decrease in the number of farms between the years of 2001 and 2006 from 522 farms to 483 (Peel Data Centre, 2007, p. 2). Notably, the majority of farms in the ROP were located in Caledon (389), followed by Brampton (76) and then Mississauga (18) (p. 2). The farms in Brampton and Mississauga were also smaller than the farms in Caledon (p. 2) which is unsurprising considering the former are both close to being built-up. This inconsistency is likely to skew the average size farm in the ROP which was 57.4 hectares or 141.81 acres.

The largest output of the agricultural sector is livestock which includes: beef, dairy and the equine industry (p. 1). This accounts for $31.4 \%$ of all farms (p. 1). The second biggest output is fresh flowers, maple syrup, honey, fruits and vegetables at $26.4 \%$ (p.1). Another significant portion consists of oilseed and grain crops at $24.6 \%$ which can be seen below in Figure 2 (p. 1). The other 17.6\% encompasses: hay, other animal production, poultry, and sheep and goats (p. 2). 


\section{Farms Classified by Industry Group in Peel \\ 2011}

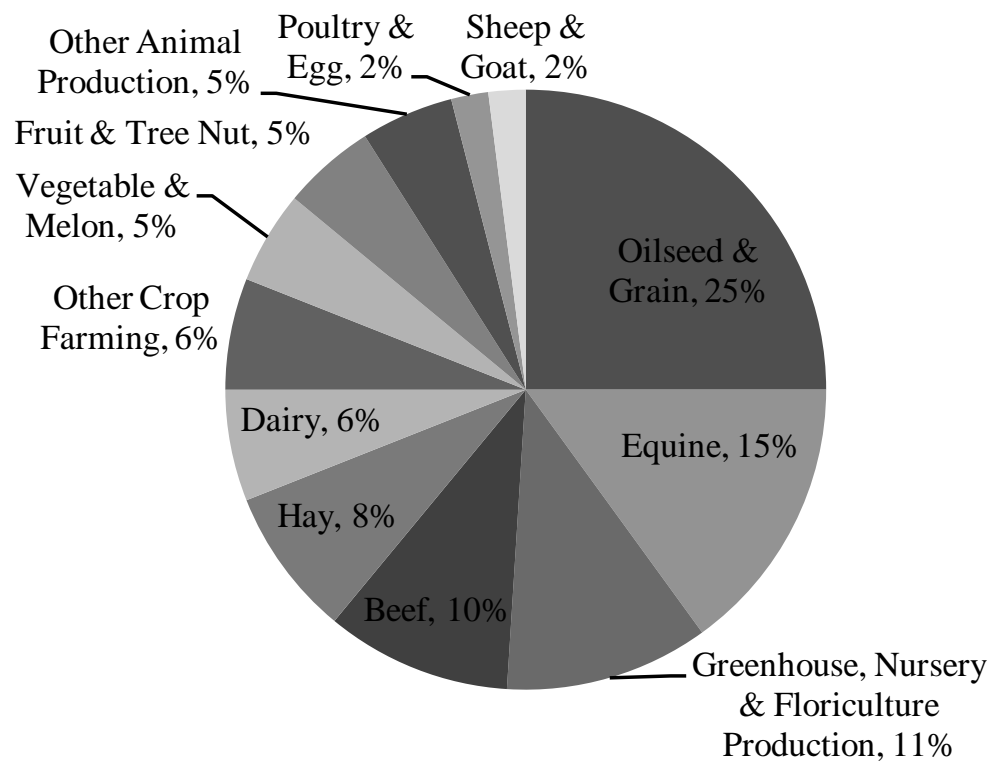

Figure 2: Farms Classified by Industry Group in Peel 2011 (Peel Data Centre, 2013).

Comparable farm and farm operator statistics are presented by the Ontario Ministry of Agriculture, Food and Rural Affairs (OMAFRA) (2014) in their tables "Number of Census Farms by County, 1991, 1996, 2001, 2006 and 2011" and "Census Farms Classified by Industry, by County, 2011". In addition, "Census Farms Classified by Size of Operation, by County, 2011" relates small farms 1-129 acres are predominant in the ROP comprising of $65.69 \%$ of all farms (2014). Medium to large size farms (130-559 acres) are smaller in number with the exception of 56 acres and over at $10.45 \%(2014)$.

\subsection{METHODS}

In this section, a spotlight will be placed on defining sustainability as it provides the basis for my thesis. The Green Bin Program Sustainability Criteria which were based on this definition will also be explained and the literature review and in-person interviews necessary to answer my research question will be detailed. 


\subsection{Sustainability Defined}

As the concept of sustainability is an essential component to the completion of this thesis, the term needs to be defined accurately, concisely, and in context for the paper. The World Commission on Environment and Development (1987) provides the most common definition of sustainability in relation to sustainable development. Sustainability is "development that meets the needs of the present without compromising the ability of future generations to meet their own needs" (World Commission on Environment and Development, 1987, p. 41). The concept of "needs" and the idea of placing "limitations" on ourselves for the good of future generations is essential to this definition and provides a good start in defining sustainability (p. 41). However, this definition is often applied to sustainable development in developing countries and the need to improve their economy and society as a part of development (p. 41). As a result, this definition does not lend itself well to waste management programs in developed countries which are more focused on their relationship with the environment. Sustainability can also be thought of as being made up of three pillars: environmental, social and economic that are interrelated and of equal importance (Opp \& Saunders, 2012, p. 679). A typical image depiction involves the three pillars holding up and supporting a roof that represents sustainability. In this system, each pillar can be considered to be a necessary aspect of sustainability.

Environmental sustainability involves maintaining nature's services at a level that is suitable (Moldan et al., 2012, p. 7). The purpose of maintaining these services is not just to protect natural beauty but human well-being which is dependent on the natural services that the environment provides (pp. 6-7). Ecosystem services, such as the purification of air, the provision of drinking water, and the decomposition of wastes are necessary for survival. Moreover, the care for these natural systems by humans often translates to an overall concern for nature, thus allowing other species to benefit as well (p. 7). However, a question remains: at what level is environmental sustainability considered suitable? The go-to answer is carrying capacity which refers to "...the number of individuals of a given species that can be sustained in an area indefinitely, given a constancy of resource supply and demand" (Dearden \& Mitchell, 2009, pp. 102-103). The idea is that a species' population will increase with the availability of raw materials and fluctuate and diminish naturally when reaching the carrying capacity allowing time for the raw materials to regenerate (p. 103). Regrettably, we as humans often forget about the 
well-being of other species and only maintain these services to the point where there are no negative side effects for humans.

Economic sustainability is based on the basic supply and demand principle which involves cost savings and profit, economic growth and research, and development (Rodriguez et al., 2002, p. 8). The example of the current financial and economic crisis is provided by Moldan et al. (2012) whereas economic growth is considered the norm with little consideration being given to sustainability (p. 5). This indicates that even currency needs to be used in a sustainable manner which is a concept that can be illustrated through the supply and demand dynamic. There is no sense in throwing money into the supply of an item without the presence of demand.

Social sustainability is the most poorly defined of the three and is often excluded in sustainability studies (Opp, \& Saunders, 2012, p. 681). This is largely due to social equity already being related to the economic and environmental condition of communities and thus is addressed by association (Saha, 2009, p. 18). Moreover, the diverse economic, social, and cultural conditions in a given country differ greatly making the concept difficult to apply (Moldan et al., 2012, p. 5). In an effort to differentiate the social sphere, Rodriguez et al. (2002), highlight education, community, and equal opportunity as important factors (p. 8). Building on this concept, Black (2004) states that social sustainability is the extent that social values, social identities, and social relationships are able to continue into the future (p. 2). In a similar vein, Gilbert et al. (1996) had defined social sustainability in the past as the ability of society to work towards common goals through cohesion (p. 12). Nonetheless, even this definition only provides a general goal for social sustainability rather than attempting to define it (Colantonio, 2007, p. 4).

There are two notable models that implement the three pillars of sustainability as integrated and dependent on one another including: "Deep Ecology and Strong Sustainability" (Meadows et al., 1972) and "The Three Spheres of Sustainability" (Rodriguez et al., 2002, p. 8). The first considers the environment, the economy, and society as three rings nested one inside of the other thus signifying the limitations of environmental carrying capacity on the economy and society (Meadows et al., 1972). The second regards the environmental, economic and social aspects of sustainability as three overlapping circles with equal influence (Rodriguez et al., 2002, p. 8). It is at the centre of this diagram, where all three rings overlap that sustainability is achieved (p. 8). 
Deep Ecology and Strong Sustainability

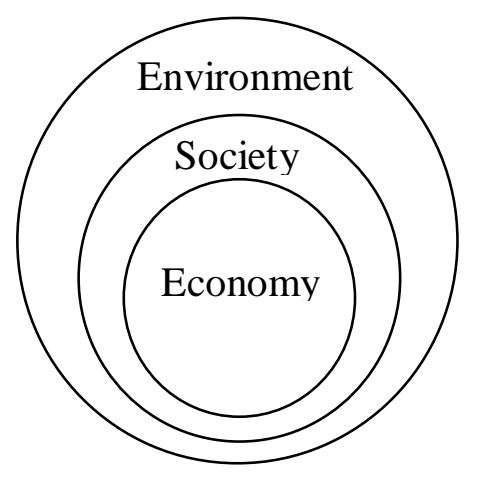

The Three Sphere of Sustainability

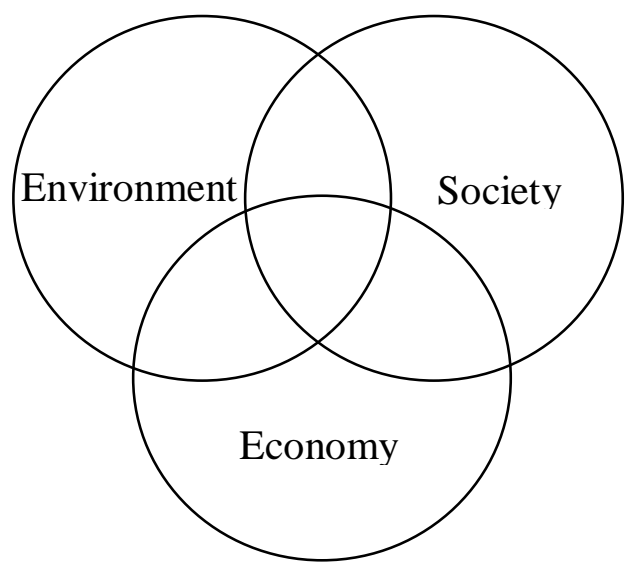

Figure 3: Deep Ecology and Strong Sustainability Versus The Three Spheres of Sustainability.

At the same time, this model indicates that when two neighbouring rings overlap, new fields of interest are created (p. 8). For instance, an environmental-economic overlap results in: environmental efficiency, environmental accounting, and ecological tax reform (p. 8). Similarly, an economic-social overlap produces: business ethics, fair trade, and human rights while a social-environmental overlap raises concern about: environmental justice, environmental refugees, and inter-generational equity (p. 8).

Although SWM is indeed limited by the environment (i.e. landfill capacity), the Green Bin program attempts to reduce the impact of the economy and society. The diversion of organics inherent in this program arguably increases or at least prolongs the carrying capacity of the environment as it reduces the amount of organic material destined for landfills and allows resources to be re-used. Rather than being limited by the environment, the Green Bin program is more likely to be limited by the amount of organic waste created by the population and the ROP's capacity to deal with it in terms of facilities and equipment. Moreover, the economic and social aspects play an equal role to the environment in the success of the program. Without consideration of the economic or the social aspects, the program will likely fail despite being well within the boundaries of the environment. Therefore, the second theory of the Three Spheres of Sustainability which considers all three as equal is more appropriate for the study. 


\subsection{The Sustainability Criteria, Categories and Measures}

"The Three Spheres of Sustainability" provide the basis for analyzing the Green Bin program and the result can be seen below in Figure 4: Green Bin Program Sustainability Criteria. The column on the left titled "Category of Sustainability" lists the environmental, economic, and social spheres. Each sphere is broken down into three accompanying "Criteria" listed in the middle column of the table. These Criteria provide guiding questions concerning an aspect of the Green Bin program's sustainability from the perspective of the environmental, economic or social spheres. The "Measures" qualify and quantify the Criteria by narrowing the focus. Some of the Measures are based on research into the ROP's policies, while others require data analysis from interviews and statistical data.

\begin{tabular}{|c|c|c|c|}
\hline \multicolumn{4}{|c|}{ Green Bin Program Sustainability Criteria } \\
\hline $\begin{array}{c}\text { Category of } \\
\text { Sustainability }\end{array}$ & Criteria & & Measure \\
\hline \multirow[t]{3}{*}{ Environmental } & $\begin{array}{l}\text { Is the organic waste } \\
\text { being repurposed? }\end{array}$ & $\begin{array}{l}\text { i. } \\
\text { ii. } \\
\text { iii. }\end{array}$ & $\begin{array}{l}\text { Where are the Region of Peel's } \\
\text { composted organics going? } \\
\text { Would the addition of the Green Bin } \\
\text { Agriculture Test improve on the } \\
\text { Green Bin program? If so, how? } \\
\text { Does the Green Bin program help the } \\
\text { Region of Peel achieve 70\% } \\
\text { diversion? Is the Region likely to } \\
\text { reach its goal? What challenges does } \\
\text { it face? }\end{array}$ \\
\hline & $\begin{array}{l}\text { Is the compost free of } \\
\text { harmful chemicals? }\end{array}$ & $\begin{array}{l}\text { i. } \\
\text { ii. } \\
\text { iii. }\end{array}$ & $\begin{array}{l}\text { Is there a guarantee of quality and if } \\
\text { so, what does it cover? } \\
\text { What procedures are in place to } \\
\text { maintain the quality? } \\
\text { What measures are in place to educate } \\
\text { households on this topic? }\end{array}$ \\
\hline & $\begin{array}{l}\text { Are environmental } \\
\text { externalities limited } \\
\text { (i.e. climate change)? }\end{array}$ & $\begin{array}{l}\text { i. } \\
\text { ii. } \\
\text { iii. }\end{array}$ & $\begin{array}{l}\text { How do carbon credit incentives } \\
\text { encourage the reduction of } \\
\text { Greenhouse Gases? } \\
\text { How does the production of } \mathrm{CO}_{2} \text { on } \\
\text { the farm compare in compost use } \\
\text { versus fertilizer use? } \\
\text { How many carbon credits would be } \\
\text { saved in the Region of Peel? }\end{array}$ \\
\hline Economic & $\begin{array}{l}\text { Is there interest by } \\
\text { farmers? }\end{array}$ & i. & $\begin{array}{l}\text { Assess current municipal compost use } \\
\text { by farmers and their future interest in } \\
\text { the Region of Peel. }\end{array}$ \\
\hline
\end{tabular}




\begin{tabular}{|c|c|c|c|}
\hline & & iii. & $\begin{array}{l}\text { What concerns do Peel farmers have } \\
\text { about using municipal compost? (Are } \\
\text { they different by agricultural } \\
\text { industry?) } \\
\text { How do participating farmers } \\
\text { compare to non-participating farmers } \\
\text { in terms of views on compost use and } \\
\text { concerns? }\end{array}$ \\
\hline & $\begin{array}{l}\text { Does it make sense for } \\
\text { the farmers to buy } \\
\text { compost? }\end{array}$ & $\begin{array}{l}\text { i. } \\
\text { ii. } \\
\text { iii. }\end{array}$ & $\begin{array}{l}\text { How does the price of municipal } \\
\text { compost and chemical fertilizer } \\
\text { compare? } \\
\text { How do the costs to transport and } \\
\text { apply municipal compost and } \\
\text { chemical fertilizer compare? } \\
\text { How does the yield compare when } \\
\text { using municipal compost and } \\
\text { chemical fertilizer? }\end{array}$ \\
\hline & $\begin{array}{l}\text { Is there enough supply } \\
\text { and demand? }\end{array}$ & $\begin{array}{l}\text { i. } \\
\text { ii. } \\
\text { iii. }\end{array}$ & $\begin{array}{l}\text { Can demand be created? Can supply } \\
\text { be increased? Can we balance them? } \\
\text { What does the marketing campaign } \\
\text { involve? (Are there physical } \\
\text { advertisements available, information } \\
\text { online, information sessions?). } \\
\text { How far reaching is the marketing in } \\
\text { regard to the Region of Peel } \\
\text { residents? }\end{array}$ \\
\hline \multirow[t]{2}{*}{ Social } & $\begin{array}{l}\text { Do all residents have } \\
\text { access to the Green Bin } \\
\text { program? }\end{array}$ & $\begin{array}{l}\text { i. } \\
\text { ii. }\end{array}$ & $\begin{array}{l}\text { Does local by-law require residents to } \\
\text { participate in organic waste } \\
\text { separation? To what extent? } \\
\text { Are residents asked to provide } \\
\text { written/verbal commitment to divert } \\
\text { organics? } \\
\text { Are there any groups that do not or } \\
\text { are more likely not to have access to } \\
\text { the program? Why do they not have } \\
\text { access? }\end{array}$ \\
\hline & $\begin{array}{l}\text { Is the compost } \\
\text { equitably priced? }\end{array}$ & $\begin{array}{l}\text { i. } \\
\text { ii. } \\
\text { iii. }\end{array}$ & $\begin{array}{l}\text { Is it affordable to the general public? } \\
\text { To farmers? } \\
\text { Are there extra expenses associated } \\
\text { with compost that the user would not } \\
\text { be able to easily absorb? What are } \\
\text { these expenses? } \\
\text { Is extra equipment required for its use } \\
\text { that potential buyers may not already } \\
\text { have? }\end{array}$ \\
\hline
\end{tabular}




\begin{tabular}{|l|l|ll|}
\hline & $\begin{array}{l}\text { Is there a public } \\
\text { awareness/educational } \\
\text { campaign available? }\end{array}$ & i. & $\begin{array}{l}\text { What information is available to } \\
\text { residents on what does go into the } \\
\text { Green Bins? }\end{array}$ \\
ii. & $\begin{array}{l}\text { What strategies are in place to reduce } \\
\text { waste/consumption? }\end{array}$ \\
iii. $\begin{array}{l}\text { What information is there on the } \\
\text { various uses of compost? }\end{array}$
\end{tabular}

Figure 4: Green Bin Program Sustainability Criteria.

As indicated above, the Criteria pertaining to the Environmental Category of Sustainability will be focusing on: 1) the role of the Green Bin program in the overall diversion strategy, 2) the compost quality, and 3) the function of the Green Bin program as a climate change mitigation strategy. With the goal of assessing the sustainability of the ROP's compost throughout its lifecycle, the stages of natural resource use, environmental management, and pollution prevention will be addressed (Rodriguez et al., 2002, p. 8). These three areas of investigation were highlighted not only because they are important considerations for the environment but because they provide perspective on the overall success of the Green Bin program in diverting waste from landfills. The Environmental Sustainability Measures will:

a) Quantify the tonnage of raw organics collected in the ROP per year and the tonnage of compost produced per year to assess the re-purposing of organics, using data attained from the ROP and the demographic statistics.

b) Evaluate the quality assurance process through a document analysis.

c) Determine the amount of $\mathrm{CO}_{2}$ reduction through a fertilizer vs. compost comparison and an estimation of potential carbon credits.

The Criteria for the Economic Category of Sustainability are based on a basic supply and demand principle (p. 8). Accordingly, the Green Bin Program Sustainability Criteria highlights: 1) determining farmer interest in buying municipal compost from the ROP, 2) establishing whether it makes financial sense for farmers to buy compost, and 3) assessing the ROP's capacity to keep up with the supply and demand for compost. For compost sale to be a viable solution for the Green Bin program, it needs to be economically sound with a good balance of both supply and demand. An analysis of the farmer's willingness to "buy-in" to the compost, given the benefits (i.e. cost savings, profit and economic growth) and the ROP's capacity to produce the 
required amount of compost will provide insight into feasibility of this dynamic. The Economic Criteria will:

a) Evaluate the current use of compost and future interest in using it through the analysis of farmer responses from in-person interviews and data attained from the ROP.

b) Determine the benefits and draw backs of using compost through yield comparisons from the Green Bin Agricultural Test sample plot data, responses from farmer interviews, and cost comparisons of fertilizer vs. compost conducted by OMAFRA.

c) Assess current marketing strategies and make recommendations to improve through a review of the ROP's website and the analysis of responses from farmer interviews. In order to accurately answer the questions posed by the Economic Category of Sustainability, in-person interviews were conducted with two groups of farmers: farmers who are participating in the Green Bin Agriculture Test and farmers who are not a part of the test. Both groups were asked general questions about their farming operation (e.g. type of crops, acreage, yield, years farming) to gain insight into their demographic data (1a-f). Current municipal compost use by farmers and future interest were noted through questions concerning what product/practise they currently use to enrich the soil (1.d), whether they have used compost in the past (4), their opinion about compost replacing chemical fertilizer (5) and whether compost is viable for large farm operations (6). The benefits and drawbacks of using municipal compost were also discussed through various questions about the farmer's experience with municipal compost, chemical fertilizer and other soil enrichment products. Furthermore, to assess the ROP's compost marketing strategies, the farmers were asked if they are familiar with the Green Bin Agriculture Test (7). The answers for "participating" and "non-participating" farmers will be compared where applicable in the following section in order to draw conclusions.

The social sphere of the Three Spheres of Sustainability is the most poorly defined of the three (Opp, \& Saunders, 2012, p. 681). For the Green Bin program, the facets of community participation highlighted by Rodriguez, et al. (2002) will ensure residents are not only knowledgeable, but involved and have equal access to resources (p. 8). Therefore, the aim of the Criteria established for Social Category of Sustainability is to assess: 1) residential access to the Green Bin program, 2) the equitable pricing of compost, and 3) public awareness and/or educational campaigns. For the Green Bin program, this Criteria is meant to ensure equality of 
access for both households and farmers, their input and participation. This will be determined through an evaluation of the ROP's information dissemination strategies and also the analysis of farmer interviews. The Social Sustainability Measures will:

a) Determine whether access to organic kitchen composting is available/mandated to all residents through an examination of the service standards on the ROP's website.

b) Establish what farmers consider equitably priced compost through in-person interviews, and a review of the ROP's pricing structure.

c) Evaluate the extent of the information available to residents on the ROP's Green Bin program, waste reduction and the use of compost by assessing the ROP's website.

\subsection{In-Person Interviews with "Participating" and "Non-Participating" Farmers}

As a literature review and data analysis alone are unlikely to communicate the real world situation of farmers in the ROP, in-person interviews were conducted with two distinct groups of farmers. "Participating" farmers refer to those that are currently participating in the Green Bin Agriculture Test while "non-participating" farmers are not a part of the compost trials. Additional eligibility criteria for "non-participating" farmers include being an owner/operator/manager of a census farm located in the ROP, while all "participating" farmers were eligible to participate. Notably, "participating" farmers were not limited to operating a farm in the ROP. These two groups were selected to determine the impact of the Green Bin program and the Green Bin Agricultural Test on the opinions, challenges and experiences of farmers. Topics of interest covered during the interview include: soil amendment choice, experiences with compost, the perceived impact of climate change and participation in farmer co-ops. The interview consists of twelve open-ended questions which can be viewed in the Appendix A. There are two sets of interview questions, one for "participating" farmers and one for "nonparticipating" farmers that were compared where applicable to find common themes. As such, the interview includes some of the same, parallel and unique questions which is outlined in detail in Figure 5: "Participating" and "Non-Participating" Farmer Interview Question Breakdown. A question both groups of farmers are asked is: "Do you feel climate change has an impact on your farming? What kind of impact? Positive? Negative? None?" (11.a)(2.a). An example of question used in "participating" farmer interviews is: "Tell me about your decision to participate in the 
Green Bin Agriculture Test?" (2a-c) while "non-participating" farmers are asked: "Have you had any past experience with farmer co-ops or other similar programs? Please describe them" (10). There are also questions unique to "non-participating" farmers, such as questions 5: "In your opinion will compost ever be able to completely replace chemical fertilizer?" and question 6: "Do you think compost is a viable alternative for large scale farm operations?". Although, these exact questions were not asked in the "participating" farmer interview, the farmer's stance on compost was. The questions were designed to encourage in-depth conversation with the subject in order to gain a thorough understanding of their perspective on the issues discussed.

\begin{tabular}{|l|l|l|}
\hline \multicolumn{2}{|c|}{ "Participating" and "Non-Participating" Farmer Interview Question Breakdown } \\
\hline $\begin{array}{l}\text { Same/Parallel/Unique } \\
\text { Questions }\end{array}$ & "Participating" Farmer & "Non-participating" Farmer \\
\hline Same & $1 \mathrm{a}-\mathrm{f}$ & $1 \mathrm{a}-\mathrm{f}$ \\
\hline Same & $11 \mathrm{a}$ & $2 \mathrm{a}$ \\
\hline Same & $12 \mathrm{a}$ & $3 \mathrm{a}$ \\
\hline Parallel & 5 & 4 \\
\hline Unique & - & 5 \\
\hline Unique & - & 6 \\
\hline Parallel & $2 \mathrm{a}-\mathrm{c}$ & $7 \mathrm{ab}$ \\
\hline Parallel & $2 \mathrm{a}-\mathrm{c}, 3,4,5,6,8,9 \mathrm{a}, 10$ & 8 \\
\hline Same & 13 & 9 \\
\hline Parallel & $2 \mathrm{a}-\mathrm{c}, 3,4,7,8,10$ & 10 \\
\hline Parallel & $3,4,7,8,10$ & 11 \\
\hline Same & 10 & 12 \\
\hline
\end{tabular}

Figure 5: "Participating" and "Non-Participating" Farmer Interview Question Breakdown.

The Ethics Review submission for this thesis was approved by the Ryerson Ethics Board (REB) during the summer of 2015. Two sets of interview questions, a consent form, and flyers advertising the study for "participating" and "non-participating" farmers, and a phone and an email script were included in the application. These can be viewed in Appendix A, B, C and D respectively. The REB letter stating that the thesis was approved can be found in Appendix E.

A multi-prong recruitment strategy for "non-participating" farmers was devised: a) flyers were delivered into the mailboxes of one hundred farm properties in the ROP, b) the ROP's chapter of the Ontario Farmer's Association (OFA) was contacted via email requesting that the recruitment email and flyers be distributed to their eighty members, c) sixteen eligible famers listed on the "Grown in Peel" website were called or emailed, d) twelve eligible ROP farmers 
from the website Eat Local were called or emailed and e) the twenty eligible farms listed in the Yellow Pages for Brampton, Caledon and Mississauga were contacted. Approximately 228 farmers were contacted all together. This number is an estimation due to the possibility of duplication as the identities of both the mailboxes and the ROP OFA contacts are unknown. According to statistics from the Peel Data Centre (2013, p. 1) and the OMAFRA (2014) there are 440 census farms in the ROP and therefore around half of this number were successfully contacted for the study. Unfortunately, there was no information available publicly to contact the other half of census farms that are assumed to want to remain anonymous. It is also worth mentioning that the contact information provided in the Yellow Pages and on farmer websites such as Grown in Peel and Eat Local may be outdated as some replies from farmers indicated they were no longer farming or were no longer located in the ROP. Further, a practice of leasing the land to large farming operations has been noted in the ROP.

As a result of the recruitment efforts, sixteen interviews were conducted with "nonparticipating" farmers in the ROP where as ten to fifteen interviews were expected. Due the low number of farmers participating in the Green Bin Agriculture Test (14), a goal of five interviews was initially established. This group of farmers was contacted with the help of Christine Brown who is a head on the project and sent out the recruitment email with the attached flyer to farmers on my behalf. All five projected interviews were successfully completed with this group. In order to draw conclusions about farmers in the ROP, the interview data will be extrapolated using the Peel Data Centre data and OMAFRA census data. Assuming the "non-participating" farmers interviewed are similar in terms of industry breakdown to the data on the whole of the ROP, then the findings can reasonably be generalized.

\subsection{INTERVIEW DATA ANALYSIS}

In this section, the interview data compiled will be analyzed. This includes the data from the "participating" and "non-participating" farmer interviews which will be compared to the ROP statistics and further, the two groups will be compared to each other. Moreover, the data will be analyzed as a part of the results section and used to help draw conclusions. Ultimately, the results of the data analysis will be used to evaluate the sustainability of the Green Bin program and to draw conclusions. 


\section{1 "Participating" and "Non-participating" Farmer Interview Data}

With the approval of the REB, five interviews were successfully conducted with "participating" farmers and sixteen interviews with "non-participating" farmers. Out of the five "participating" farmers, one was from the ROP, one was from the Regional Municipality of Halton, one was from Haldimand County, one from Middlesex County and one was from Strathroy-Caradoc. As previously stated, the farmer industry classifications obtained from the 2011 Census Bulletin for Agriculture will be compared to the classifications from the interview participants to determine whether the data gathered can be extrapolated (Peel Data Centre, 2013). Figure 6: Farmer Industry Classification Comparison shows a comparison between the farm industry classification of the ROP's farmer population data and the sample interview data. In the left column, the farmer industry classifications are listed. In the middle left column, the ROP percentages of farmers involved in the industry classifications are indicated and to the middle right the interview percentages are listed.

\begin{tabular}{|l|l|l|c|}
\hline \multicolumn{1}{|c|}{$\begin{array}{c}\text { Farm Industry } \\
\text { Classification }\end{array}$} & $\begin{array}{c}\text { Percentage of Region } \\
\text { of Peel (ROP) } \\
\text { Farmers (\%) }\end{array}$ & $\begin{array}{c}\text { Percentage of "Non- } \\
\text { Participating" } \\
\text { Farmers (\%) }\end{array}$ & $\begin{array}{c}\text { Percentage of } \\
\text { "Participating" } \\
\text { Farmers (\%) }\end{array}$ \\
\hline Oilseed \& Grain & $25 \%$ & $25 \%$ & $80 \%$ \\
\hline Equine & $15 \%$ & $6.25 \%$ & $0 \%$ \\
\hline $\begin{array}{l}\text { Greenhouse, Nursery } \\
\text { \& Floriculture }\end{array}$ & $11 \%$ & $0 \%$ & $0 \%$ \\
Production & $10 \%$ & $6.25 \%$ & $0 \%$ \\
\hline Beef & $8 \%$ & $12.5 \%$ & $0 \%$ \\
\hline Hay & $6 \%$ & $6.25 \%$ & $0 \%$ \\
\hline Dairy & $6 \%$ & $0 \%$ & $0 \%$ \\
\hline Other Crop Farming & $25 \%$ & $0 \%$ \\
\hline Vegetable \& Melon & $5 \%$ & $18.75 \%$ & $0 \%$ \\
\hline Fruit \& Tree Nut & $5 \%$ & $0 \%$ & $0 \%$ \\
\hline $\begin{array}{l}\text { Other Animal } \\
\text { Production }\end{array}$ & $5 \%$ & $0 \%$ & $0 \%$ \\
\hline Poultry \& Egg & $2 \%$ & $0 \%$ & $0 \%$ \\
\hline Sheep \& Goat & $2 \%$ & & \\
\hline
\end{tabular}

Figure 6: Farmer Industry Classification Comparison.

Half of the "non-participating" farmers interviewed fall within 5\% of the industry classifications. The representation of the interview participants in the Oilseed \& Grain industry is the same as 
the statistical data at $25 \%$ of total participants. Meanwhile, the Hay and Dairy farmers interviewed are both very close to the ROP statistic with a $4.5 \%$ and a $0.25 \%$ gap respectively. In the ROP data, Other Animal Production, Poultry \& Egg and Sheep \& Goat make up a small percentage of the total at $5 \%, 2 \%$, and $2 \%$.

The farm industries of Equine and Beef are both within $10 \%$ and are still fairly reasonable comparisons. It is assumed that the farm industry designations change rapidly as farmers are adapting each growing season to the market realities. Moreover, many farmers engage in more than one industry classification. For example: Hay and Equine, or Hay and Beef, or Vegetable \& Melon and Poultry \& Eggs. Further, crops are rotated regularly and the practise of leasing the land is common. Given the realities of today's farming and the fact that the census took place in 2011, some variation is inevitable. Overall, while some of the results are different, they are not significantly different.

Another comparison worth making for the "non-participating" farmers is the size of operation in terms of the number of acres on the farm. The data for the size of operation in the ROP was sourced from the OMAFRA (2014) and the resulting table can be seen below as Figure 7: Size of Operation Comparison. The number of farms that fall into a given size of operation and the accompanying percentage of the total is included for both the ROP and the "nonparticipating" farmer interviews.

\begin{tabular}{|l|l|l|l|l|l|}
\hline \multicolumn{5}{|c|}{$\begin{array}{c}\text { Size of } \\
\text { Operation }\end{array}$} & \multicolumn{2}{|c|}{ Region of Peel (ROP) } & \multicolumn{2}{c|}{$\begin{array}{c}\text { "Non-Participating" } \\
\text { Interview }\end{array}$} & $\begin{array}{c}\text { Percentage } \\
\text { Difference }\end{array}$ \\
\cline { 2 - 5 } & $\begin{array}{l}\text { Number of } \\
\text { Farms }\end{array}$ & $\begin{array}{l}\text { Percentage } \\
(\%) \text { of } \\
\text { Farms }\end{array}$ & $\begin{array}{l}\text { Number of } \\
\text { Farms } \\
(\%) \text { of } \\
\text { Farms }\end{array}$ & \\
\hline $1-9$ acres & 45 & $10.23 \%$ & 2 & $12.50 \%$ & +2.27 \\
\hline $10-69$ acres & 163 & $37.05 \%$ & 4 & $25 \%$ & -12.05 \\
\hline $70-129$ acres & 81 & $18.41 \%$ & 1 & $6.25 \%$ & -12.16 \\
\hline $130-179$ acres & 26 & $5.91 \%$ & 1 & $6.25 \%$ & +0.34 \\
\hline $180-239$ acres & 24 & $5.45 \%$ & 2 & $12.5 \%$ & +7.05 \\
\hline $240-399$ acres & 33 & $7.50 \%$ & 0 & $0 \%$ & -7.50 \\
\hline $400-559$ acres & 22 & $5 \%$ & 0 & $0 \%$ & -5 \\
\hline $\begin{array}{l}560 \text { acres \& } \\
\text { over }\end{array}$ & 46 & $10.45 \%$ & 6 & $37.50 \%$ & +27 \\
\hline
\end{tabular}

Figure 7: Size of Operation Comparison. 
Although none of the percentages for the sizes of operation are exactly the same, a number are quite similar including the categories of 130-179 acres, 1-9 acres, and 400-559 acres. On the other hand, there was quite a difference in the 560 acres \& over, 70-129 acres and 10-69 acres size of operation. Notably, there are a high number of smaller farms in the ROP that are 10-63 acres and 70-129 acres (OMAFRA, 2014). These are under-represented in the interview percentages. A smaller number of farms in the 400-559 acres, 180-239 acres and 130-179 acres categories are reflected well in the interviews. The data shows that overall a variety of sizes of operations were captured in the interviews with both ends of the spectrum: small and large farms represented. The over and under representation of certain categories may skew the data providing that farmers in the same size bracket share similar experiences and opinions. Thus, a possible false impression may be created concerning common threads in the interview scripts.

\subsection{RESULTS}

The results of the Green Bin program literature review and the in-person interviews will be discussed by methodically following the Green Bin Program Sustainability Criteria. All three Categories of Sustainability will be examined individually starting with the Environmental Measures, followed by the Economic Measures and concluding with the Social Measures. The interview responses for each set will be used to answer the associated Criteria.

\subsection{Environmental Category of Sustainability}

The goals of the Green Bin program resonate with the Environmental Category of Sustainability in particular due to the emphasis on waste reduction and bettering the environment. In this section, the Criteria discussed will cover the following topics: success in repurposing organic waste, the presence of harmful chemicals in compost, and externalities experienced; in particular: climate change. Below, Figure 8: Environmental Criteria and Measures highlights the three Criteria and nine Measures specific to the Environmental Category of Sustainability. 


\begin{tabular}{|c|c|c|c|}
\hline \multicolumn{4}{|c|}{ Environmental Criteria and Measures } \\
\hline $\begin{array}{c}\text { Category of } \\
\text { Sustainability }\end{array}$ & Criteria & & Measure \\
\hline \multirow[t]{3}{*}{ Environmental } & $\begin{array}{l}\text { Is the organic waste } \\
\text { being repurposed? }\end{array}$ & $\begin{array}{l}\text { i. } \\
\text { ii. } \\
\text { iii. }\end{array}$ & $\begin{array}{l}\text { Where are the Region of Peel's } \\
\text { composted organics going? } \\
\text { Would the addition of the Green Bin } \\
\text { Agriculture Test improve on the } \\
\text { Green Bin program? If so, how? } \\
\text { Does the Green Bin program help the } \\
\text { Region of Peel achieve } 70 \% \\
\text { diversion? Is the Region likely to } \\
\text { reach its goal? What challenges does } \\
\text { it face? }\end{array}$ \\
\hline & $\begin{array}{l}\text { Is the compost free of } \\
\text { harmful chemicals? }\end{array}$ & $\begin{array}{l}\text { ii. } \\
\text { iii. }\end{array}$ & $\begin{array}{l}\text { Is there a guarantee of quality and if } \\
\text { so, what does it cover? } \\
\text { What procedures are in place to } \\
\text { maintain the quality? } \\
\text { What measures are in place to educate } \\
\text { households on this topic? }\end{array}$ \\
\hline & $\begin{array}{l}\text { Are environmental } \\
\text { externalities limited } \\
\text { (i.e. climate change)? }\end{array}$ & & $\begin{array}{l}\text { How do carbon credit incentives } \\
\text { encourage the reduction of } \\
\text { Greenhouse Gases? } \\
\text { How does the production of } \mathrm{CO}_{2} \text { on } \\
\text { the farm compare in compost use } \\
\text { versus fertilizer use? } \\
\text { How many carbon credits would be } \\
\text { saved in the Region of Peel? }\end{array}$ \\
\hline
\end{tabular}

Figure 8: Environmental Criteria and Measures.

The Criteria and the associated Measures will be discussed in the order displayed above in the sections of the paper that follow.

\subsubsection{Environmental Criterion: Is the Organic Waste Being Re-purposed?}

The ultimate fate of the organic kitchen waste and the yard waste that is collected by the ROP's trucks is the first Environmental Criterion's main concern and will provide a good start for determining the overall sustainability of the program. To start, an inquiry as to where the ROP's composted organics are going will be necessary as indicated below in the Measures column of Figure 9. A breakdown of the life cycle of the collected organic kitchen waste and yard waste will help to determine this. However, a look into the long term waste diversion goals of the municipality will also be necessary. 


\begin{tabular}{|c|c|c|c|}
\hline \multicolumn{4}{|c|}{ Environmental Criterion 1} \\
\hline $\begin{array}{c}\text { Category of } \\
\text { Sustainability }\end{array}$ & Criterion & & Measure \\
\hline Environmental & $\begin{array}{l}\text { Is the organic waste } \\
\text { being repurposed? }\end{array}$ & & $\begin{array}{l}\text { Where are the Region of Peel's } \\
\text { composted organics going? } \\
\text { Would the addition of the Green Bin } \\
\text { Agriculture Test improve on the } \\
\text { Green Bin program? If so, how? } \\
\text { Does the Green Bin program help the } \\
\text { Region of Peel achieve } 70 \% \\
\text { diversion? Is the Region likely to } \\
\text { reach its goal? What challenges does } \\
\text { it face? }\end{array}$ \\
\hline
\end{tabular}

Figure 9: Environmental Criterion 1.

Specifically, the findings of the Green Bin Agriculture Test will be discussed. Further, it will be investigated whether the Green Bin program will help the ROP achieve its $70 \%$ diversion rate. There is an important distinction to be made between these two programs whereas the Green Bin program is an organics collection service by the ROP while the Green Bin Agriculture Test is a partnership between the ROP, OMAFRA and farmers to test compost yields. The Green Bin program is the ROP's current municipal organics collection program and will be discussed in further detail in the following sections.

Environmental Measure i

Before looking at where the ROP's compost finally ends up, it is important to consider where it comes from. As previously stated, the ROP has a Green Bin curb-side collection program for kitchen waste and yard waste which is converted into compost (Region of Peel, 2015c). In 2014, it was reported that 329,600 households in the ROP out of 361,975 total (Statistics Canada, 2015) participated in Green Bin curb side collection (L. Conrad, personal communication, October 15, 2015). From these residents, 29,853.92 tonnes of organics were collected as well as 53,307.44 tonnes of leaf and yard waste (2015). In total, 83,161.36 tonnes were collected and out of the total, 62,678 tonnes were processed by the Peel Integrated Waste Management Facility (PIWMF) and Caledon CRC (2015). This decrease in tonnes from the amount collected versus the amount processed may reflect the removal of plastics, glass and other materials as a part of the screening process. Furthermore, some of the organic material was sent to a third party for processing (2015). 
The process of composting, which is described by Partanen et al. (2010) is an aerobic process where micro-organisms biologically degrade organic waste, resulting in the creation of compost (p. 1471). It begins with the input of organic materials, such as food wastes, yard waste, feed wastes or other organic materials that are high in carbon $(\mathrm{C})$, nitrogen $(\mathrm{N})$ and other nutrients (Martin, 2005, p. 2). During this process, the carbon in the organics is broken down by microorganisms and is lost as $\mathrm{CO}_{2}$ (p. 1). Heat is lost (p. 2) and water evaporates resulting in the volume of the compost decreasing and the nutrients becoming more concentrated (p. 1). Notably, some nitrogen is also lost but the rest will be converted into nitrate $\left(\mathrm{NO}_{3}{ }^{-}\right)$and ammonia $\left(\mathrm{NH}_{3}\right)$ which are slowly released for plant uptake (p. 1). The end product should be $40-60 \%$ of its original volume (p. 1) and should not contain any pathogens or viable seeds (Partanen et al., 2010, p. 1471). In the end, the quality of compost is the result of several factors including: the oxygen content, the moisture, the composition of the organic matter, the $\mathrm{pH}$, and the temperature (p. 1471).

In the ROP it takes 8 weeks for the compost to cure and as a result, 12,410 tonnes of finished compost were sold in 2014 (L. Conrad, personal communication, October 15, 2015). An additional 3,705 tonnes were sent to third party and 4,067 tonnes to a mine reclamation project in Sudbury (2015). Assuming that only the 12,410 tonnes were sold at $\$ 5$ to $\$ 7$ per tonne, the estimated compost sales for 2014 were between $\$ 62,050$ to $\$ 86,870$.

\section{Environmental Measure ii}

The central focus of the Green Bin Agriculture Test is to determine the long-term impacts of compost and its benefits for agriculture (Region of Peel, 2015e). Based on this description it is apparent that the Green Bin Agriculture Test is focused on the application benefits and marketing of the Green Bin program compost rather than the collection or curing of organics. To determine the success of the Green Bin Agriculture Test and by association whether it improves the Green Bin program, a look into what the trials have achieved is pertinent.

Year 1 of the Green Bin Agriculture Test involved monitoring, sampling and data collection (Brown, 2014, p. 6). More specifically, the ROP and the OMAFRA were interested in determining the value of the Green Bin compost as a soil amendment, its Organic Matter (OM) content, best application, the logistics, and economics (p. 6). First, the compost was found to have a good balance of nitrogen, phosphorus and potassium (NPK) with a low risk of N loss (p. 
7). The OM content is high and there is low odour associated with the cured compost (p. 7). In terms of the best application, the compost was found to be easier to apply uniformly to a field than most solid manure (p. 7). It also has an unrestricted designation that makes it easier to access and handle than biosolids or manure (p. 7). There is however, a concern about contaminants, such as plastic and glass (p. 8). Lastly, the compost has a low bulk density which makes transportation more expensive and impacts the logistics and economics (p. 8). The timing of product availability and application may also be a challenge (p. 8). Evidently, the Year 1 results indicate that there are benefits present for soil health with compost use; however, issues such as contaminants, transportation expenses and timing of product availability and application may be problematic for farmers as a potential sales market.

In Year 2 and 3, farmers were involved in side-by-side yield comparisons between plots that implemented municipal compost and plots that did not use any soil amendment. The results are indicated below in Figure 10: Complete Yield Chart (C. Brown, personal communication, October 14, 2015).

\begin{tabular}{|c|c|c|c|c|}
\hline \multicolumn{5}{|c|}{ Complete Yield Chart } \\
\hline Location & Crop & $\begin{array}{l}\text { With Compost } \\
\text { (bu/ac) }\end{array}$ & $\begin{array}{l}\text { Without Compost } \\
\text { (bu/ac) }\end{array}$ & \% Change \\
\hline Oakland (2011) & Corn & 212.3 & 203 & 4.4 \\
\hline $\begin{array}{l}\text { Bowmanville field } 1 \\
(2012)\end{array}$ & Corn & 188.9 & 186.7 & 1.2 \\
\hline $\operatorname{Meek}(2012)$ & Corn & 96.7 & 90.4 & 6.5 \\
\hline Orton (2012) & Corn & 104.9 & 96 & 8.4 \\
\hline Wainfleet (2012) & Corn & 139 & 147 & $(5.4)$ \\
\hline Winchester (2012) & Corn & 191.3 & 191.5 & $(0.1)$ \\
\hline Jarvis (2013) & Corn & 119.4 & 115.5 & 3.3 \\
\hline Plattsville (2013) & Corn & 186.7 & 171.3 & 8.2 \\
\hline Strathroy (2013) & Corn & 152.8 & 145.3 & 4.9 \\
\hline Winchester (2013) & Corn & 219.3 & 207.0 & 5.5 \\
\hline Castleton (2014) & Corn & 154.5 & 150 & 3 \\
\hline Strathroy (2014) & Corn & 181.7 & 164.4 & 12.4 \\
\hline Winchester (2014) & Corn & 137.3 & 141 & $(2.6)$ \\
\hline $\begin{array}{l}\text { Acton Field } 1 \\
(2013)\end{array}$ & Forage & $\begin{array}{c}1.59 \text { (ton/ac) } \\
1,344 \text { (lbs milk/ac) }\end{array}$ & $\begin{array}{c}1.59 \text { (ton/ac) } \\
991 \text { (lbs milk/ac) }\end{array}$ & $\begin{array}{l}0 \\
26.3\end{array}$ \\
\hline $\begin{array}{l}\text { Acton Field } 2 \\
(2013)\end{array}$ & Forage & $1.76(\mathrm{ton} / \mathrm{ac})$ & $1.63($ ton/ac) & 7.8 \\
\hline Castleton (2012) & Soybeans & 33.5 & 31.0 & 7.5 \\
\hline
\end{tabular}




\begin{tabular}{|l|l|c|c|l|}
\hline $\begin{array}{l}\text { Bowmanville field 1 } \\
(2013)\end{array}$ & Soybeans & 29.5 & 29.5 & $\mathbf{0}$ \\
\hline $\begin{array}{l}\text { Bowmanville field 2 } \\
(2013)\end{array}$ & Soybeans & 43.8 & 41.3 & $\mathbf{5 . 7}$ \\
\hline Meek (2013) & Soybeans & 56 & 53 & $\mathbf{5 . 3}$ \\
\hline Wainfleet (2013) & Soybeans & 60.2 & 58.3 & $\mathbf{3 . 1}$ \\
\hline Winchester (2013) & Soybeans & 48.5 & 50.1 & $\mathbf{( 3 . 2 )}$ \\
\hline Strathroy (2014) & Soybeans & 43.8 & 39.3 & $\mathbf{1 0 . 3}$ \\
\hline Thorndale (2013) & Strawberries & $2.42(\mathrm{~kg})$ & $2.08(\mathrm{~kg})$ & $\mathbf{1 3 . 9}$ \\
\hline Castleton (2013) & Wheat & 78 & 72 & $\mathbf{7 . 7}$ \\
\hline Meek (2014) & Wheat & 74.5 & 67.9 & $\mathbf{8 . 9}$ \\
\hline
\end{tabular}

Figure 10: Complete Yield Chart (C. Brown, personal communication, October 14, 2015).

Based on this table, the majority of sites reported an increase in yield with municipal compost application as seen in the far right column "\% Change" which indicates the percent difference between the compost plot and the control plot. Aside from the instances mentioned above, there are a few sites that reported a higher yield on the plot without compost (indicated in brackets). Three out of four of these sites grew corn while the one grew soybeans. Notably, corn was a prominent crop in the site tests and the majority of them resulted in a positive increase for the municipal compost plot. In fact, Strathroy (2014) saw the biggest increase at $12.4 \%$ for corn. Soybeans, which were not as prominent in the tests were positive at all other sites although, more testing may be required. The site with the greatest boost for soybeans was Strathroy (2014) at $10.3 \%$. The sites with the greatest change overall was Acton field (2013) which planted a forage crop that saw a $26.3 \%$ increase. Also, the largest improvement for wheat was $7.7 \%$ at Castleton (2013) and for strawberries, $13.9 \%$ at Thorndale (2013).

For the most part, it can be said that compost has a positive impact on yield over the control without compost. In terms of composition, the best results came from nitrogen-rich compost produced from residential source-separated organics (p. 2). The problem with compost is the high expense to obtain, transport and apply as opposed to competing soil amendments such as manure or chemical fertilizer (p. 1). It was found that most participants would not use compost at full cost and a few indicated it should be subsidized or free in return for benefits to municipalities (p. 2). While the Green Bin Agriculture Test is essential in establishing scientific evidence for a positive correlation between compost and increased yields, the scale of the test is small and there are crop and soil variances. Overall, the Green Bin Agriculture Test allowed the 
ROP to affirm the benefits of compost use and the potential interest by farmers. However, based on these results, it is likely that the ROP will have to find new ways to appeal to and involve farmers on a larger scale. The ongoing usefulness of the Green Bin Agriculture Test depends on the next steps that the ROP takes towards establishing relationships with farmers.

\section{Environmental Measure iii}

A waste diversion rate of $70 \%$ by 2016 had been previously set by the ROP (Pollock, 2006, p. 3). On October 8th, 2015, the Council of the Regional Municipality of Peel increased the 3Rs target for waste diversion to $75 \%$ by 2034 (Boughton, 2015). It was also decided that the ROP's Organics Program would be expanded to include materials that can be effectively managed through the program such as: diapers, sanitary products, pet waste, and similar materials once the new Anaerobic Digestion (AD) Facility is operational (2015). Further, plastic bags will also be allowed as Green Bin liners (2015). The staff of the Council of the Regional Municipality of Peel intend to report back at a future meeting on the implications of the higher target diversion rate (2015).

The follow up meeting which occurred on November 19th, 2015 indicated that the first $60 \%$ of the diversion target is expected to be reached through approved 3Rs policies, programs and approaches (Lee, 2015a, p. 5). However, the remaining 15\% would require a review of policy and program changes (p. 9). In addition, an approval of the preferred approach would be required by the end of term (p. 9). Based on these meetings, it is evident that the ROP is achieving its waste diversion goals as new goals are continuously being adopted. In regards to the recent goal, achieving the additional 15\% diversion will require change on the part of the ROP. There is an emphasis on the new AD Facility and the benefit of diverting additional materials from the waste stream with the Green Bin program. In fact, the Infrastructure Development Plan (IDP) identified AD as the preferred method for treating Green Bin organics (Lee, 2015b, p.21). A key finding for the ROP is the current infrastructure for processing Green Bin organics is over capacity (p. 22). In contrast, AD facilities are able to deal with a greater variety of Green Bin materials than regular composting in addition to being equipped to handle high amounts of contamination (p. 22). Facilities can be constructed in areas that are already built up and the biogas produced as a result of the process can be used as renewable energy ( $\mathrm{p}$. 
22). In short, the Green Bin program will be essential to the ROP achieving its waste diversion goals in the upcoming years.

A look outwards, to the organics programs in other municipalities indicates that there is still room for improvement in the ROP. The Regional Municipality of Halton (2014) which has its own Green Bin program also organizes the on-going collection of storm brush, while the ROP only collects storm brush at certain points of the year (p. 1). A different approach is taken by the Regional Municipality of York (2016) which encourages backyard composting and provides information to residents on how to set up a home composter and what kinds of materials can go in. Moreover, the City of Toronto (2016) uses compost on parks and farmland. Clearly, there are still a variety of materials that can be diverted and municipalities are working on expanding the services available to their residents. At the same time, certain residents may not necessarily have access to the collection services thus missing the opportunity to increase the diversion rate. For instance, the collection of organics is expected to be expanded to multi-family facilities in the ROP in 2016 (L. Conrad, personal communication, October 15, 2015). This will be discussed in detail with the Social Criteria and Measures but for the purposes of this section, identifying and dealing with these gaps provides a means for the ROP to improve their services.

\subsubsection{Environmental Criterion: Is the Compost Free of Harmful Chemicals?}

A fundamental question from the environmental perspective is whether the compost is free of harmful chemicals. As organics and yard waste are recycled, it is imperative that harmful substances are not introduced into the soil and ultimately into our food. Below in Figure 11, the Criterion is broken down into the following three Measures: 1) a guarantee of compost quality 2) procedures to maintain the quality, and 3) public education.

\begin{tabular}{|c|l|ll|}
\hline \multicolumn{2}{|c|}{ Environmental Criterion 2 } \\
\hline $\begin{array}{c}\text { Category of } \\
\text { Sustainability }\end{array}$ & \multicolumn{1}{|c|}{ Criterion } & \multicolumn{1}{c|}{ Measure } \\
\hline Environmental & $\begin{array}{l}\text { Is the compost free of } \\
\text { harmful chemicals? }\end{array}$ & i. & $\begin{array}{l}\text { Is there a guarantee of quality and if } \\
\text { so, what does it cover? }\end{array}$ \\
& ii. & $\begin{array}{l}\text { What procedures are in place to } \\
\text { maintain the quality? }\end{array}$ \\
& iii. $\begin{array}{l}\text { What measures are in place to educate } \\
\text { households on this topic? }\end{array}$ \\
\hline
\end{tabular}

Figure 11: Environmental Criterion 2. 
A guarantee of quality protects not only the user but the environment as well in terms of following best practises for producing and selling compost on the market. Discussion concerning the procedures in place to maintain the quality ensures a follow-through on the guarantee and public education is crucial to prevent the inclusion of harmful substances at the source.

\section{$\underline{\text { Environmental Measure i }}$}

Consumers are well acquainted with products that guarantee quality and offer money back if said product fails to satisfy. The ROP has a compost label which states their guarantee (J. Smit, personal communication, January 18, 2016) and can be viewed in full in Appendix F. As a part of the compost label, the ROP discloses the composting process which involves: 1) kitchen and yard waste curb-side collection, 2) inspection at the Regional composting facility before it is mixed and shredded, 3) ten days in a composting vessel, 4) transportation to a curing facility for continued breakdown and stabilization, 5) screenings for size and tests to ensure the cured compost meets regulatory standards, and 6) use in agriculture, commercial operations and homes. The composting process is described in a manner that is easy to comprehend and with accompanying images to give readers a better understanding. Further, it indicates to the user that the compost is made entirely of organic materials that residents are familiar with as they throw them into their kitchen organics bins and Green Bins on a daily basis. Notably, the fifth stage makes reference to compost standards, the Ministry of Environment's Ontario Compost Quality Standards (July 25, 2012) which are discussed in the bottom half of the compost label. This section highlights the proper compost application rate and application thickness and provides a warning for use on soils with elevated copper and zinc levels. These topics are not discussed in great detail, only indicating that if the recommended application is exceeded there will likely be negative side effects. Instead it encourages the reader to look up the proper application amounts in the official document. Last, the Compost Quality Alliance logo in the left corner of the compost label, indicates that the compost is being made with "...standardized testing methodologies and uniform operating protocols" (Compost Quality Alliance, n.d.). The methodology and protocols will be discussed in greater detail in the next section.

\section{Environmental Measure ii}

As discussed in the previous Measure, the compost label references the Ministry of Environment's Ontario Compost Quality Standards (July 25, 2012) and the Compost Quality 
Alliance. The incorporation of standards and programs are important for the ROP to maintain quality in its compost and the standards are beneficial regardless of whether they are enforced by external bodies or voluntarily. Foremost, the Ontario Ministry of the Environment (MOE) (2012a) established guidelines for the Province of Ontario on the aerobic composting of organic waste materials (p. 5) known as the Ontario Compost Quality Standards (July 25, 2012). Compost is categorized as Category AA, Category A or Category B (p. 11). Category AA has the highest quality standards and may be used without restrictions or approvals (Ministry of the Environment, 2012). The compost may not contain sewage biosolids, pulp and paper biosolids or septage as feedstock (2012). Category A may use biosolids as feedstock but must meet the metal standards on input of feedstock (2012). Labelling must include the maximum application rates, identification of biosolids and domestic septage and a warning about use on soils with elevated copper or zinc concentrations (2012). Category B is less restrictive for metals and foreign mater and may use biosolids but must meet the same standards as Category A (2012). It requires government approval for use and transportation (2012).

Generally speaking, there is an evident focus on the standards for metal in compost (Ontario Ministry of the Environment, 2012a, p. 11), pathogens (p. 13), foreign matter (p. 14), maturity (p. 25), and the quality of the feedstock used (p. 12). There are also labelling requirements outlined for all the different categories of compost (p. 16) and measures required for odour management in composting facilities (p. 21). In order to ensure that odour is dealt with at every stage of handling, an effective odour management plan is necessary (p. 21). The companion document, Guideline for the Production of Compost in Ontario also by the MOE (2012b) goes into depth on legislation, approvals and standards, site selection considerations and odour prevention and control (p. 3-4).

The Compost Quality Alliance (CQA) is a voluntary program established by the Compost Council of Canada (Compost Quality Alliance, n.d.). Licensing and the ability to use the CQA logo on packaging and product promotion requires compost producers to follow approved sampling frequency and reporting methods (n.d.). The program incorporates: 1) standardized product sampling of compost, 2) uniform laboratory testing and, 3) guidelines for appropriate product attributes and usage (n.d.). It is beneficial to consumers as it allows them to select the right compost for the right purpose. Moreover, it is beneficial to the compost industry as it 
supports regulatory compliance, enhances the development of the compost market, and improves the industry's credibility and reputation (n.d.). The ROP's participation in this program and compliance with the procedures indicates that it is going beyond the Ontario requirements for compost and actively pursuing additional means to improve their product.

An important set of guidelines not mentioned by the compost label but none the less influential are the Guidelines for Compost Quality written by the CCME (2005). They are intended to be Canada-wide regulations and thus Provincial regulation such as the MOE's Ontario Compost Quality Standards (July 25, 2012) must adhere to them. The CCME established guidelines for compost safety and quality are based on the amount of foreign matter, maturity, pathogens and trace elements (p. 1). Further, two grades were established for the materials, Category A - unrestricted and Category B - restricted (p. 1). Category A - unrestricted compost can be used for any application from agriculture to the nursery industry (p. 11). Use of Category $\mathrm{B}$ - restricted is limited due to the presence of sharp foreign matter or higher trace element content (p. 11). Additional control from the Province or Territory may be required (p. 11). Evidently, the Ontario regulations were built on the National guidelines; however, the former has improved on the latter by expanding on the number of categories. In general, for compost of any grade to be acceptable, it should be cured for a minimum of twenty-one days, not exceed a respiration rate of 400 milligrams or a temperature of $8^{\circ} \mathrm{C}$, to name a few (p. 14). There are also requirements for pathogens that vary depending on whether the compost contains only yard waste or other feedstock as well (p. 15-16). Lastly, the organic contaminants will likely vary based on the source; however, routine analysis under the CCME Guidelines is not considered necessary (p. 16). Clearly, the ROP is in compliance with both provincial and national standards for compost quality otherwise the municipality would not be permitted to sell compost. In addition, the ROP has gone above and beyond by actively participating in a compost group dedicated to improved sampling and reporting.

\section{Environmental Measure iii}

Education is an important component of the Green Bin program as it involves residents in the production of organics and in purchasing the finished compost product. The ROP's strategy for advertising and informing residents about compost includes: the flyers and booklets residents receive with their Green Bins, the ROP website and the compost label. A yearly Waste 
Collection Calendar is provided to residents that indicates the collection schedule for organics, yard waste and other curb-side collection materials. There are also instructions on how to set out your cart from the placement to the timing of pickup. A fridge magnet is included that is titled "What Goes in Your Green Bin" and details acceptable food waste, paper products and other items. It also highlights common non-acceptable items. The Region of Peel 2014/2015 Waste Management Guide, a booklet provided for residents includes similar information but with more detail as all the collection schedules for different neighbourhoods are listed. There is no mention of harmful chemicals in compost or compost quality presented in any of these media.

On the ROP website, residents can search collection schedules by address and find detailed information on how to sort their waste (Region of Peel, 2015g). Residents can also report a missed collection, broken or damaged carts or provide feedback or a complaint (2015g). Additional information is also available by bin type allowing residents to familiarize themselves with the organics and yard waste bins (2015g). The Organics information states the material collected is transformed into compost and includes the Organics (Green) Cart Owner's Manual available for download (Region of Peel, 2015h). The Yard Waste section consists of information on bin/container size and labels and that drop-off at CRCs is free of charge (Region of Peel, 2015i). There is no mention of compost in this section. In the Compost information segment, it is affirmed that residents can buy compost from CRCs and further information on how to buy a composter and participate in grasscycling are discussed (Region of Peel, 2015c). There is no mention of compost quality or information on harmful chemicals in the compost. Moreover, there is no discussion about recommended application or links for further information.

As discussed in the previous Measures, the compost label references the MOE's Ontario Compost Quality Standards (July 25, 2012). Although the compost label gives the reader an idea of how the compost should be used, it does not explain with enough detail and directs them to other sources. It is unlikely that residents in the ROP looking to use the compost will have the time or interest to read the additional document. Moreover, the information provided be these sources only provide a general understanding of compost standards and quality rather than informing the reader specifically about ROP compost. In short, the ROP does little to educate the public on compost quality or the presence of harmful chemicals in compost. During the in-person interviews, a number of "non-participating" farmers indicated that they were concerned about 
metals and foreign matter in their compost. This concern was especially prevalent in organic farmer responses due to the need to maintain their certification which involves knowing the exact source of the compost.

\subsection{Environmental Criterion: Are Environmental Externalities Limited?}

Environmental externalities are expected with any production process and that includes Green Bin programs which reuse and repurpose organic waste materials. Therefore, the main concern of the final Environmental Criterion is climate change as an environmental externality of the composting process as indicated by Figure 12.

\begin{tabular}{|c|l|ll|}
\hline \multicolumn{2}{|c|}{ Environmental Criterion 3 } \\
\hline $\begin{array}{c}\text { Category of } \\
\text { Sustainability }\end{array}$ & \multicolumn{1}{|c|}{ Criterion } & \multicolumn{1}{c|}{ Measure } \\
\hline Environmental & $\begin{array}{l}\text { Are environmental } \\
\text { externalities limited } \\
\text { (i.e. climate change)? }\end{array}$ & i. & $\begin{array}{l}\text { How do carbon credit incentives } \\
\text { encourage the reduction of }\end{array}$ \\
Greenhouse Gases?
\end{tabular}

Figure 12: Environmental Criterion 3.

The first and second Measures attempt to answer this the most directly by considering carbon credits and the GHGs associated with climate change. Specifically, the role of carbon credits in encouraging the reduction of GHGs and how the production of $\mathrm{CO}_{2}$ on the farm compares with compost use versus fertilizer use. Assuming that the Green Bin Agriculture Test allows carbon credits to be saved by farmers, the potential benefits of reducing climate change can be explored. Last, the process of earning and trading carbon credits will be determined based on the ROP statistics.

\section{Environmental Measure i}

Generally speaking, climate change is a long term shift in weather conditions which can be measured via climate indicators (i.e. temperature, precipitation, wind) (Government of Canada, 2015). In relation to the Green Bin Agriculture Test, climate change refers to shifts in climate caused by the "greenhouse" effect. Normally, a thin layer in the atmosphere naturally 
made of GHGs controls the earth's temperature (Goetz et al., 2009, p. 379). However, the thickening of this layer due to the addition of anthropogenic GHGs has resulted in the warming of the earth's atmosphere in what is known as the "greenhouse effect," (p. 379). Commonly emitted GHGs in the agriculture sector include methane $\left(\mathrm{CH}_{4}\right)$ and nitrous oxide $\left(\mathrm{N}_{2} \mathrm{O}\right)$ (Brethour, \& Klimas, 2008, p. 8). These emissions come from animal production, specifically, enteric fermentation $\left(\mathrm{CH}_{4}\right)$ and manure management $\left(\mathrm{N}_{2} \mathrm{O}^{15}\right.$ and $\left.\mathrm{CH}_{4}\right)$ (p. 8). Also, $\mathrm{N}_{2} \mathrm{O}$ is released from agriculture soils (pp. 8-9). Consider, in Canada the agriculture sector released 68 tonnes of $\mathrm{CO}_{2}$ equivalents in 2011 (Environment Canada, 2013, p. 15). Due to Canada's northern latitude, it is expected that climate change impacts will be more pronounced (Poutiainen et al., 2013, p. 403).

To minimize the impacts of climate change, an emissions trading system that implemented carbon credits has been proposed as a part of the Green Bin Agriculture Test. Emissions trading refers to a market-based regulatory tool used to reduce the cost associated with limiting GHG emissions into the atmosphere (Goetz et al., 2009, p. 381). Although the main concern of the Green Bin Agriculture Test is to reduce waste headed for landfills, farmers who use the ROP's Green Bin compost in place of chemical fertilizer could potentially save carbon credits due to a reduction in GHGs released into the atmosphere. This is achieved through a "cap" and "trade" system which requires a government or regulatory agent to set a limit or "cap" on emissions (p. 381). Allowances represent the total emissions permitted under this cap and are divided into units which are equal to one tonne of emissions released (Butters, 2003, p. 5). A certain number of allowances are allocated by the government or regulating agent and represents the amount of a pollutant that a particular industry is allowed to release within a year (p. 5). These regulated entities are not allowed to have their emissions exceed their allowances and if they do exceed them, must purchase excess allowances from another entity whose emissions is less than its allowance (Goetz et al., 2009, p. 381). In order to track progress and create confidence in the system, a rigorous emissions measurement monitoring system is often necessary (Butters, 2003, p. 4).

Currently, there is no nation-wide carbon credits system in Canada and the Green Bin Agriculture Test has yet to advance to this stage in the trials. However, in April 2015 Premier Kathleen Wynne announced that Ontario will launch a cap-and-trade system for carbon 
emissions that will be linked to Quebec and California's systems (Morrow, 2015). As a part of this program, permits will be issued by the governments jointly and therefore companies in Quebec, for instance, can buy permits from companies in California (2015). This alliance is also beneficial in that a more stable carbon price will be established over time due to a greater number of companies participating (2015). The carbon market will include 61 million people and cover over half of Canada's economy (2015). Assuming Ontario proceeds without delay, the Green Bin Agriculture Test will have the opportunity to be a leader and test the emissions trading program.

\section{Environmental Measure ii}

Public awareness of climate change and the risks it poses have lead to everyday people looking for ways to reduce their carbon footprint. Actions taken range from major lifestyle changes such as riding a bicycle to work instead of driving a car to smaller changes including eating less red meat. The same can be said for farmers and the agricultural sector which are constantly evolving to meet the needs of the consumer. To begin, a brief look into the perspectives of "participating" and "non-participating" farmers on climate change will help determine their interest. In the "participating" farmer interviews, four out of five respondents discussed the impact extreme weather has on their crops such as soil erosion due to heavy rain and hot/dry summers resulting in no moisture for crops. Interestingly, two responded that there were both positive and negative impacts of climate change and one indicated they had seen no impacts. In regards to "non-participating" farmers, one indicated that climate change has had a positive impact for them due to the warm weather improving the yield. However, eight reported a negative impact whereas three mentioned weather extremes and two cited water issues. Notably, four saw no impact and one saw both positive and negative impacts due to the reduced growing time for crops and longer winters resulting in less blight-threatened plants. As with the previous group, one farmer chose not to respond. Evidently, there are various opinions present among both groups; however, the idea that climate change will cause extreme weather and potentially impact their profession negatively is prominent.

The idea of small replacements such as the use of compost over chemical fertilizer that could potentially reduce the release of $\mathrm{CO}_{2}$ on the farm will now be explored. Practically speaking, the application of chemical fertilizer versus compost on the field was noted by several 
farmers to differ greatly in effort and thereby emissions. In particular, compost was found to be more labour intensive as it requires more rounds with a spreader due to the need to restock the machine regularly. Compost is noted to have a low bulk density and as a result, a larger amount would be needed to apply the same amount of nutrients as chemical fertilizer (Brown, 2014, p. 8). However, distance covered by the spreader is also dependent on the number of acres owned by the farmer. On the other hand, emissions produced by each soil amendment once laid out on the field is something that can be quantified. According to Boldrin et al., (2009), compost contributes to both: produced emissions through the process of decomposition of organic matter and avoided emissions due to the addition of the carbon sink (p. 800). Specifically, GHGs are released into the atmosphere when organic matter is oxidized (p. 804). At the same time, the stable organic matter in the compost has a turnover of 100 to 1000 years which leaves a fraction of the carbon bound to the soil (Favoino \& Hogg, 2008, p. 65; Smith et al, 2001, p. 140). This bound carbon can be thought of as a part of a sink as it removed $\mathrm{CO}_{2}$ from the atmosphere (Favoino \& Hogg, 2008, p. 61). To put it in context, the turnover of carbon is a long-term process with steady benefits over time. In fact, a study in Australia determined that over a 20 year period, $45 \%$ of carbon applied with compost is retained (Biala, 2011, p. 5). Therefore, the compost will sequester carbon (which reduces GHGs) by 5,046 $\mathrm{kg} \mathrm{CO}_{2}$ equivalents at an application rate of 10 tonnes of Dry Matter (DM) per hectare over 20 years (p. 5). Substituting compost over the use of mineral fertilizer allows for the reduction of GHG emissions caused by the manufacturing and transportation of fertilizers (p. 35). Therefore, the GHG savings from fertilizer replacement within 20 years is $5,224 \mathrm{~kg} \mathrm{CO}_{2}$ equivalents per hectare (p. 5). It is also worth noting that the increased water retention of the soil, reduced herbicide/biocides requirements, improved soil structure and reduced erosion could produce some GHG savings with compost use (Boldrin et al., 2009, p. 806). The authors also proclaim that one of the benefits of compost is that is chemical fertilizer use can be avoided (p. 800).

\section{Environmental Measure iii}

Initially, Canada's commitment under the Kyoto Protocol was to reduce GHG emissions 6\% below 1990 levels (Brethour, \& Klimas, 2008, p. 4). Despite this, Canada's emissions rose 25.3\% above 1990 levels according to Environment Canada's 2005 national inventory (p. 5). Canada's Prime Minister (PM) at the time, Stephen Harper backed away from Kyoto 
commitments in favour of a "made-in-Canada" proposal known as Canada's Clean Air Act (Bill C-30) which proposes reducing GHG emissions 60-70\% below 2006 levels (p. 7). Unfortunately, the Act has been tabled since 2007 by the House of Commons (p.8). A more current national inventory reported that the 2014 target of 6\% below 1990 levels was expected to be surpassed (Ministry of the Environment and Climate Change, 2014, p. 4). In addition, Premier Kathleen Wynne recently announced that Ontario will launch a cap-and-trade system for carbon emissions that will be linked to Quebec and California's systems (Morrow, 2015). Based on Canada's history with carbon credits and the new proposal for an emissions trading system, an estimation can be made concerning the number of carbon credits that could be saved in the ROP.

In the ROP, 30\% of the total land was used for agriculture in 2011 (Peel Data Centre, 2013, p.1). Therefore, 37,877 hectares of agricultural land were owned, rented, leased or cropshared in the ROP (p. 4). As discussed with the previous Measure, substituting compost for chemical fertilizer results in savings of 5,224 $\mathrm{kg} \mathrm{CO}_{2}$ equivalents over 20 years (Biala, 2011, p. 5). This includes the benefits of carbon sequestration provided by the compost as the replacement itself only saves $178 \mathrm{~kg} \mathrm{CO}_{2}$ equivalents (p. 37). A carbon credit represents the right to emit one tonne of $\mathrm{CO}_{2}$ or an equivalent $\mathrm{GHG}$ such as $\mathrm{CH}_{4}$ or $\mathrm{N}_{2} \mathrm{O}$ (Lamaadar, 2011, p. 2). A quick calculation determines that $5,224 \mathrm{~kg}$ is equal to 5.224 tonnes as $1,000 \mathrm{~kg}$ is equal to 1 tonne. Similarly, $178 \mathrm{~kg}$ is equal to 0.178 tonnes. Briefly, 10 tonnes DM per hectare of compost was applied continuously in the study (p. 35). Therefore, in an ideal situation, if all of the agricultural land in the ROP made the switch from chemical fertilizer to compost, 197,869.45 tonnes of $\mathrm{CO}_{2}$ equivalent are saved or approximately 197,869 carbon credits if carbon sequestration is included in the calculation.

5.224 tonnes saved per hectare over 20 years 37,877 hectares in the ROP

5.224 tonnes $\mathrm{x} 37,877$ hectares

$$
=197,869.45 \text { tonnes } / 37,877 \text { hectares over } 20 \text { years }
$$

Without carbon sequestration, 6742.106 tonnes of $\mathrm{CO}_{2}$ equivalents are saved or 6742 carbon credits.

0.178 tonnes saved per hectare over 20 years 37,877 hectares in the ROP

$$
0.178 \times 37,877 \text { hectares }
$$




$$
=6742.106 \text { tonnes } / 37,877 \text { hectares over } 20 \text { years }
$$

Currently, there are no carbon emissions statistics available for the agriculture sector in the ROP. However, a comparison can be made with the Ontario statistics to determine whether the amount saved is worthwhile. The agriculture sector is responsible for $6 \%$ of the province's total emissions which is approximately 10.02 Mt or 10,020,000 tonnes (Ministry of the Environment and Climate Change, 2014, p. 7). Further, Ontario has 5,386,453 hectares of agricultural land as of 2006 (Statistics Canada, 2008). Therefore, 28,138,830.472 tonnes of carbon will be saved over 20 years. Thus, an average yearly saving would be 1,406,941.5236 which represents $14.04 \%$ of the total agriculture emissions per year.

Alternatively, there are 440 census farms in the ROP (Peel Data Centre, 2013) and as a result on average, 449 tonnes of $\mathrm{CO}_{2}$ equivalents would ideally be saved per farmer over 20 years if carbon sequestration is included. On the other hand, if only the replacement of chemical fertilizer is considered, 15 tonnes of $\mathrm{CO}_{2}$ equivalents would be saved. However, based on the 2014 ROP compost statistics, the municipality only produced 20,182 tonnes of compost (L. Conrad, personal communication, October 15, 2015). With the application rate of 10 tonnes per acre, this compost would be sufficient for around 2018.2 acres or 816.74 hectares of farm land. With this constraint in mind, 4,266 tonnes of $\mathrm{CO}_{2}$ would be saved over 20 years after including sequestration. The 2014 data indicate a lack of compost supply to realistically service the entirety of the ROP's agricultural land. However, demographic trends point to a steady rise in population and a shrinking of farmland thus increasing compost production and decreasing the land requiring compost. Markedly, the Beef and Dairy farm industry classifications would not use compost as manure is their primary source for soil amendment. On the other hand, the proposed $\mathrm{AD}$ facility will introduce year round production and shorten the composting process.

\subsection{Economic Category of Sustainability}

The Economic Category of Sustainability evaluates the Green Bin composting program as a business transaction between the ROP, the residents and farmers who live in the municipality. This emphasis can be seen in Figure 13 which indicates the three Criteria and nine accompanying Measures that will be discussed in detail as a part of this section. 


\begin{tabular}{|c|c|c|c|}
\hline \multicolumn{4}{|c|}{ Economic Criteria and Measures } \\
\hline $\begin{array}{c}\text { Category of } \\
\text { Sustainability }\end{array}$ & Criteria & & Measure \\
\hline \multirow[t]{3}{*}{ Economic } & $\begin{array}{l}\text { Is there interest by } \\
\text { farmers? }\end{array}$ & iii. & $\begin{array}{l}\text { Assess current municipal compost use } \\
\text { by farmers and their future interest in } \\
\text { the Region of Peel. } \\
\text { What concerns do Peel farmers have } \\
\text { about using municipal compost? (Are } \\
\text { they different by agricultural } \\
\text { industry?) } \\
\text { How do participating farmers } \\
\text { compare to non-participating farmers } \\
\text { in terms of views on compost use and } \\
\text { concerns? }\end{array}$ \\
\hline & $\begin{array}{l}\text { Does it make sense for } \\
\text { the farmers to buy } \\
\text { compost? }\end{array}$ & & $\begin{array}{l}\text { How does the price of municipal } \\
\text { compost and chemical fertilizer } \\
\text { compare? } \\
\text { How do the costs to transport and } \\
\text { apply municipal compost and } \\
\text { chemical fertilizer compare? } \\
\text { How does the yield compare when } \\
\text { using municipal compost and } \\
\text { chemical fertilizer? }\end{array}$ \\
\hline & $\begin{array}{l}\text { Is there enough supply } \\
\text { and demand? }\end{array}$ & & $\begin{array}{l}\text { Can demand be created? Can supply } \\
\text { be increased? Can we balance them? } \\
\text { What does the marketing campaign } \\
\text { involve? (Are there physical } \\
\text { advertisements available, information } \\
\text { online, information sessions?). } \\
\text { How far reaching is the marketing in } \\
\text { regard to the Region of Peel } \\
\text { residents? }\end{array}$ \\
\hline
\end{tabular}

Figure 13: Economic Criteria and Measures.

These Criteria and Measures highlight some important questions that the ROP needs to be addressing concerning their potential market. For instance, whether there is interest by farmers and if it makes sense economic for them to buy compost. More generally speaking, whether the ROP can keep up with supply and demand, not just the addition of the farmers but maintaining services to the residents of the ROP as well. All these considerations and more need to be taken into account in order to be successful in the market. 


\subsubsection{Economic Criterion: Is There Interest By Farmers?}

A major end goal of the Green Bin Agriculture Test is to expand the market for compost through a number of trials that test the compost's quality. The involvement by farmers in the trials helps to spread the word by mouth and shows that the compost can be beneficial in any situation it is placed. However, an essential question the first Economic Criterion asks is: "Is there interest by farmers?" It is important to consider the situation and interest of a group of people before marketing to them. If farmers are already using a soil amendment that they have easy access to that is cheap or even free, it is unlikely that they will use municipal compost. Notably, this Economic Criterion is concerned about the farmers in particular and not the ROP residents. Accordingly, the Measures presented in Figure 14 require an in-depth look to: 1) assess the current municipal compost use by farmers and their future interest in the ROP, 2) determine what concerns Peel farmers have about using municipal compost (are they different by agricultural industry?) and 3) compare "participating" farmers to "non-participating" farmers in terms of views on compost use and concerns.

\begin{tabular}{|c|c|c|c|}
\hline \multicolumn{4}{|c|}{ Economic Criterion 1} \\
\hline $\begin{array}{c}\text { Category of } \\
\text { Sustainability }\end{array}$ & Criterion & & Measure \\
\hline Economic & $\begin{array}{l}\text { Is there interest by } \\
\text { farmers? }\end{array}$ & $\begin{array}{l}\text { i. } \\
\text { ii. } \\
\text { iii. }\end{array}$ & $\begin{array}{l}\text { Assess current municipal compost use } \\
\text { by farmers and their future interest in } \\
\text { the Region of Peel. } \\
\text { What concerns do Peel farmers have } \\
\text { about using municipal compost? (Are } \\
\text { they different by agricultural } \\
\text { industry?) } \\
\text { How do participating farmers } \\
\text { compare to non-participating farmers } \\
\text { in terms of views on compost use and } \\
\text { concerns? }\end{array}$ \\
\hline
\end{tabular}

Figure 14: Economic Criterion 1.

In addition to determining the general interest by farmers, any initial concerns indicated will be analyzed as these can have a large impact on a farmer's decision. Comparisons will also be made between "participating" and "non-participating" farmers to determine if there are any differences in general attitudes towards compost. 


\section{Economic Measure i}

To begin, identifying the principal soil amendments used by farmers in the ROP will provide insight into their behaviours and potential interest in employing municipal compost on their farms. Figure 15 summarizes the number of "non-participating" farmers that use each soil amendment. Only the initial response of the farmer was used to create the bar graph as most farmers indicated during the interview that they implement two or more soil amendments which makes summarization difficult.

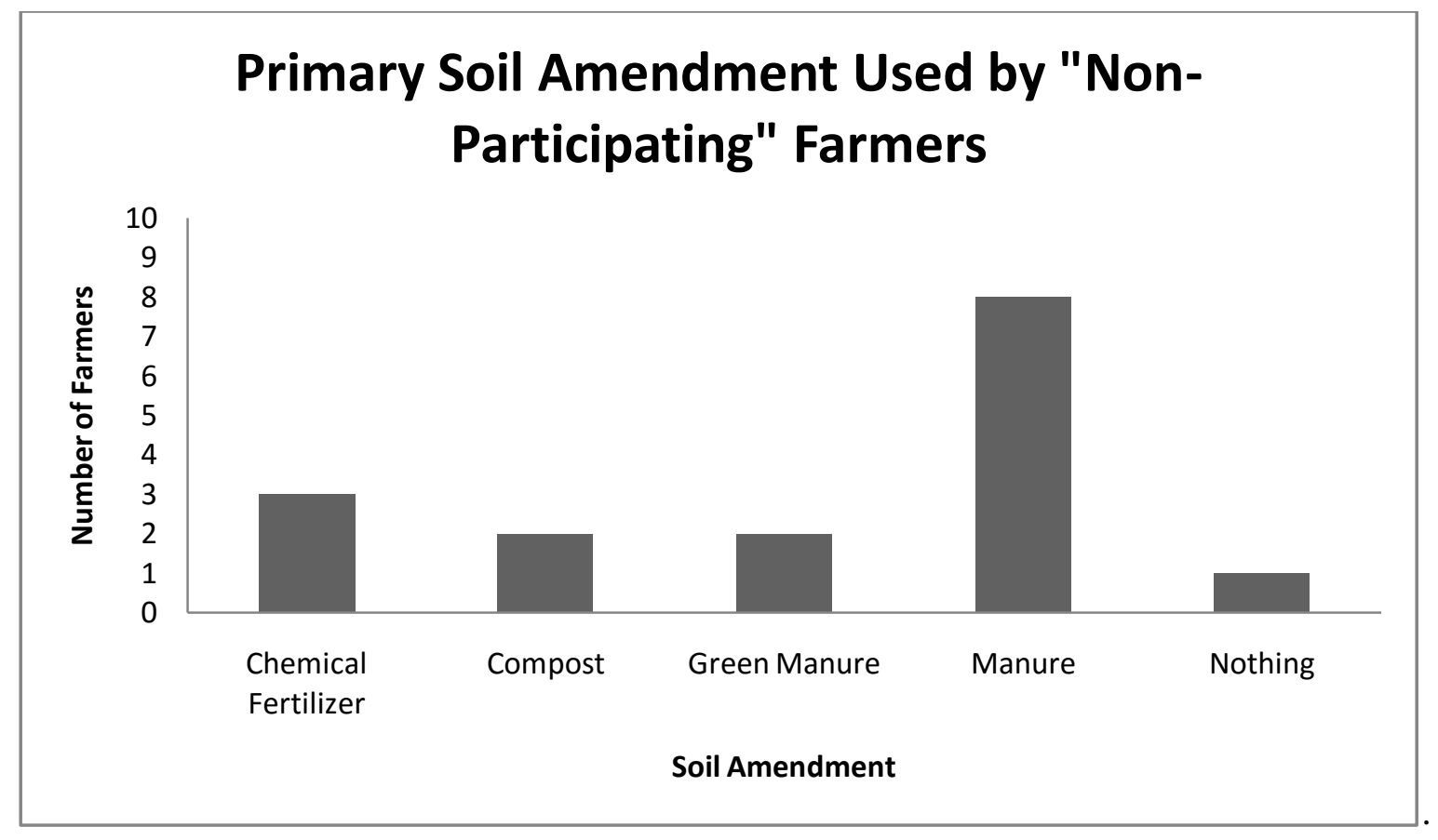

Figure 15: Primary Soil Amendment Used by "Non-Participating" Farmers.

In this bar graph, it is apparent that manure is the most popular soil amendment as eight out of sixteen farmers implement it. Notably, of these eight farmers, six use cattle manure, one uses chicken manure and one uses goat manure. The second most prominently used soil amendment is chemical fertilizer which three out of sixteen farmers apply. Interestingly, compost and green manure are both applied by the same number of farmers. Green manure refers to the parts of crops that are not harvested and thus ploughed in the ground at the end of the season to enrich the soil. This method is also referred to as cover crops whereas certain crops, such as oats and peas are strategically planted and ploughed in to improve certain characteristics of the soil. However, one of the two farmers that indicated they used compost, does not use municipal 
compost specifically, but rather a certified organic compost necessary for the farm to maintain its organic status. This is an important distinction as the Green Bin Agriculture Test is interested in selling municipal compost in particular. Further, it was noted that farmers often use the term "compost" interchangeably with "manure" in conversation thus complicating the matter. Lastly, one of the sixteen farmers does not currently use any soil amendments as the farm was previously owned by a cattle rancher.

Next, a brief look into the primary soil amendments applied by "participating" farmers will be made for comparison purposes. Although, all "participating" farmers are required to use compost on trial plots during the Green Bin Agriculture Test, the soil amendment they normally use on their farm is a personal preference. In stark contrast to the "non-participating" farmers group, only one farmer reported using manure as their soil amendment of choice. Further, three of the five farmers use compost which is comparably different from the "non-participating" farmer group. However, one of these farmers implements mushroom compost rather than municipal compost and another utilizes cover crops. Also, one farmer uses only crop rotation to provide nutrients to the soil. As this group is notably smaller than the "non-participating" farmer group, it is more difficult to state generalizations about them with confidence. However, there is a clear reliance on compost as a soil amendment over other options.

The interview results discussed above indicate that the future interest by farmers will likely be limited. Farmers in the ROP appear to mainly use manure as their primary soil amendment which is often easily available to them for no charge. Consider, out of the total number of farmers interviewed, $18.75 \%$ were Beef, Dairy and Equine farmers who would have access to an ample supply of manure for use on crops. Moreover, any neighbouring farmers would also benefit as there is often more than enough manure to go around. This situation was reported by several farmers during the in-person interviews. Similarly, cover crops, or green manure are things any farmer can easily utilize to improve their soil at no extra cost and with minimal time and effort. Although only two out of sixteen implement cover crops/green manure as their main strategy to amend their soil, six out of sixteen mentioned cover crops/green manure as one of various soil amendment strategies used. Only chemical fertilizer, which also has to be bought, is likely to be replaceable by compost. Given that transportation and application costs are a major obstacle for farmers, further steps may need to be taken by the ROP in order to make 
their product more desirable. In fact, when questioned during the interview whether municipal compost would ever be able to replace chemical fertilizer, only four out of sixteen replied "yes." The opinion that ROP compost should be provided free to ROP farmers was expressed by a number of the farmers interviewed. Similarly, the cost to buy and transport the compost was a major concern for farmers. Individually, to the two costs are manageable however, when compounded they are often difficult for the farmer to absorb.

\section{Economic Measure ii}

During the "non-participating" farmer interviews, the major concerns that arose repeatedly in conversation were: crop yield and the need to maintain soil health and water quality; competitiveness in the market; and climate change or extreme weather. All three of these issues impact the profession of farming in a very direct manner (i.e. the ability of farmers to make a living). Crop yield for instance, is directly related to profit and thus it is understandable that farmers would be unwilling to implement a soil amendment that is unfamiliar. Consider that only five out of sixteen farmers have used municipal compost before and eleven out of sixteen have not. Therefore, it is expected that the majority of concerns highlighted will centre around inexperience with the compost product. The desire to maintain soil health and water quality despite the need for a consistent high-quality yield is notable. Soil health in particular was mentioned by two farmers and having good crops was mentioned by three indicating there is concern for these issues. Competitiveness in the market usually involves reducing costs and prices in an effort to achieve greater returns. On that note, compost was previously stated to be more expensive to transport and apply and thus is not attractive to farmers who are trying to remain competitive. Last, climate change or extreme weather also negatively impact yield and are often unpredictable making the switch to compost an additional risk that farmers do not want to take. Certain years may experience more negative weather events than others and thus farmers need to make adequate preparations in advance. There were also concerns voiced about educating the public, the disappearance of land and the lack of a labour supply. These affect the farmer more indirectly but are nonetheless relevant to their decision making process.

Apprehensions voiced directly about municipal compost were mostly related to the expense of transportation and application which are very real concerns. The fact that a large number of farmers are unfamiliar with compost only amplifies this concern and results in a 
continuation of the status quo. Notably, the transportation and application expenses were most noted as a concern by the Oilseed \& Grain and Hay industries. Similarly, difficulty in attaining an amount large enough to cover the area needed was mentioned multiple times. This was reported by farmers in the industries of Oilseed \& Grain, Vegetable \& Melon and surprisingly, in Fruit \& Tree Nut who, in this case, also farmed in the Vegetable \& Melon industry. Oilseed \& Grain is usually farmed on large fields and thus, being able to obtain a supply of a sufficient amount of compost on demand is a reasonable concern. The same can be said for the Vegetable $\&$ Melon farm industry but this same response is unusual for Fruit \& Tree Nut which would have difficulty applying a large volume of compost due to the orchard lay out. In regard to the concern that the compost's extra nutrients are not enough or not worthwhile for the extra expense, this was brought up by Oilseed \& Grain and Fruit \& Tree Nut industry farmers. Notably the Fruit \& Tree Nut farmer was also farming Oilseed \& Grain. As these industries need compost in bulk, using it is a big change and the farmers need to be sure that the nutrients are just as plentiful at the same or a better price. Last, the apprehension that the origins of the compost cannot be traced was identified by Fruit \& Tree Nut and Vegetable \& Melon farmers. The latter of whom operates a certified organic farm and needs to be aware of exactly what is in the compost in order to maintain this certification. The former is concerned with metals in the compost that could show up in the fruit. Based on these industry responses it is evident that the industry classification has a large impact on the concerns faced by farmers. However, that is not to say that farmers in different industries cannot have similar concerns.

\section{Economic Measure iii}

The concerns reported from the "participating" farmer interviews are noticeably different than those of the "non-participating" farmers. Initially, there is more of an emphasis by the "participating" farmers on issues that do not directly impact the process of farming, such as public misconception and a decrease in farmland due to urban development. Although, four out of five farmers reported anxieties about making a profit, especially as prices for inputs are increasing, fewer farmers reported concerns about soil health, water quality or climate change. Notably, a number of the "participating" farmers interviewed stated that their experience with compost has been positive and it improved the water holding capacity of the soil and their yields. Issues discussed that indirectly affect farming include the recent legislation banning 
neonicotinoids due to the belief it was killing bees and therefore negatively impacting pollination. This was mentioned by three out of five "participating" farmers interviewed. All three of these farmers participate in the Oilseed \& Grain industry which are the most affected by this ban. Misinformation as a worry was also brought up by the same three out of five farmers. Examples of misinformation discussed in conversation include urbanites believing compost is human waste and the misrepresentation by large corporations that the small family farms are the norm. Evidently, there is a divergence in the concerns expressed by "non-participating" farmers and "participating" farmers.

Regarding concerns related directly to compost, three out of five "participating" farmers were positive about compost use and noted no major issues with municipal compost. Several benefits were mentioned and it was expressed that compost is seen as cleaner than manure. Notably, of the five farmers interviewed, four reported their primary agriculture industry to be Oilseed \& Grain. However, one of these four also participates in the Sheep \& Goat industry and another also participates in the Vegetable \& Melon industry. The fifth farmer participates in the Dairy and Hay industries. The problems with compost brought up by this group include time limitations and smell. First, farming was described as a time consuming job in discussion. The challenge of attaining a large quantity of compost to be utilized at a very specific point in the farming process was seen as an obstacle especially due the limited hours for pick up (e.g., 9 a.m. to 2.30 p.m.). Second, compost smell and the resulting complaints from neighbours stated to be an obstacle some years but not others. Evidently, there are fewer concerns reported by "participating" farmers versus "non-participating" farmers although this is likely reflective of the number of total farmers interviewed. However, the two groups are also vastly different in terms of total population which makes them difficult to compare, especially when considering farmer industries.

\subsubsection{Economic Criterion: Does It Make Sense for the Farmers to Buy Compost?}

In this section, the costs associated with compost use will be compared to that of chemical fertilizer. As with any business, farmers must consider the advantages and disadvantages of investing in a certain product. The expense calculation is a major part of this consideration and as such, the second Economic Criterion asks: "Does it make sense for the 
farmers to buy compost?" As indicated by Figure 16, answering this question will involve a comparison of municipal compost versus chemical fertilizer in regard to the initial price, the additional cost of transportation and application and the impact on yield.

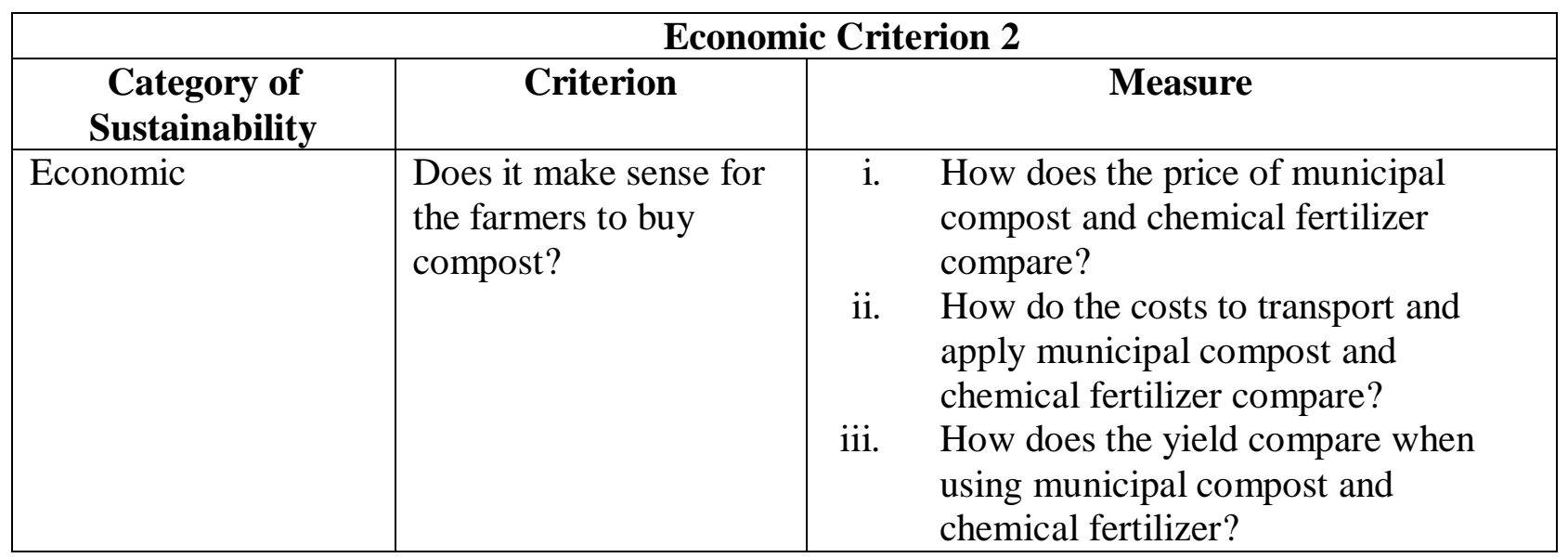

Figure 16: Economic Criterion 2.

It is important to recognize that costs include not only those experienced at the point of economic transaction but during transportation and application as well. Moreover, the resulting yield is an important consideration especially for certain farmer industry groups.

Economic Measure i

As discussed, the municipal compost that is available to farmers in the ROP can be purchased for \$5-7 per tonne (Brown, 2014, p. 32). The spreadability of this compost is 10 tonnes/acre for the maximum benefit (Middlesex County Council, 2014, p. 2). Therefore at this rate of application, the cost to cover an acre is $\$ 50-70$. Notably, the customer is responsible for pick-up and transportation.

Generally speaking, the cost for fertilizer varies depending on the product used where as the range in today's market is $\$ 450-850$ per tonne (S. Caughill, personal communication, March 7, 2016). The most commonly used fertilizer products by farmers available at Holmes Agro are blends of urea ( $\$ 550$ per tonne), MAP ( $\$ 800$ per tonne) and potash ( $\$ 525$ per tonne) (G. Hodgins, personal communication, March 8, 2016). Spreadability for a corn crop is 400-500 lbs per acre (S. Caughill, personal communication, March 7, 2016) or 0.2 to 0.25 tonnes per acre. Therefore, a range for price can be calculated per acre as seen below.

Urea $\$ 550 \times 0.2$ tonnes/acre $=\$ 110$ per 0.2 tonnes/acre. 


$$
\$ 550 \times 0.25 \text { tonnes/acre }=\$ 137.50 \text { per } 0.25 \text { tonnes/acre } .
$$

MAP $\$ 800 \times 0.2$ tonnes/acre $=\$ 160$ per 0.2 tonnes $/$ acre.

$\$ 800 \times 0.25$ tonnes/acre $=\$ 200$ per 0.25 tonnes/acre.

Potash $\$ 525 \times 0.2$ tonnes $/$ acre $=\$ 105$ per 0.2 tonnes $/$ acre .

$\$ 525 \times 0.25$ tonnes/acre $=\$ 131.25$ per 0.25 tonnes/acre.

Notably, bagging the fertilizer is optional and there is an additional charge for bags ( $\$ 40$ per tonne) and delivery is an option at $\$ 18$ per tonne, otherwise customer pick-up is at no charge (G. Hodgins, personal communication, March 8 , 2016). The ROP does not provide a delivery service for compost.

\section{Economic Measure ii}

The transportation and application of compost costs after the point of purchase are often expenses that farmers have to absorb as they are rarely considered by venders. Whether a farmer buys ROP compost or another soil amendment entirely may be impacted by these additional expenses. As a part of the Green Bin Agriculture Test, compost was provided to participating farmers for experimentation purposes which required the ROP to consider expenses from the farmer's point of view. This experience has indicated to the ROP that both the transportation and application cost of compost will differ with distance (Brown, 2014, p. 13). Regarding the transportation of compost specifically, distance depends on the farmer's location relative to the local CRCs. As previously stated, there are six CRCs in the ROP including two in Brampton, two in Caledon, and two in Mississauga (Region of Peel, 2015d). The CRCs appear to be reasonably spread out; however, it is important to consider that there are more farmers located in the Town of Caledon than the City of Brampton or the City of Mississauga. On the other hand, there are still farmers present in these two locations and they operate farms of various sizes which arguably makes this set up beneficial.

The cost to transport compost and chemical fertilizer was also determined to be variable and thus warrants discussion. In particular, ROP compost was determined to have a low bulk density ( $20 \mathrm{lbs} /$ cubic foot) which makes transportation expensive (Brown, 2014, p. 8). In fact, it is the biggest expense associated with the Green Bin Agriculture Test (p. 32). Considering that more compost is needed to supply the same nutrition as chemical fertilizer, larger volumes and more trips will be needed thus making it undesirable compared to chemical fertilizer. This 
applies to both the transportation and application for compost whereas more trips will be required with the spreader to apply the compost due to the need for greater volumes. In particular, the cost of spreading was determined to amount to \$3-5 per tonne (Brown, 2014, p. 32). This becomes difficult for farmers who may require compost in large quantities due to sheer acreage such as Oilseed \& Grain industry farmers or those that have a limit on time to successfully apply their chosen soil amendment. In addition, the fertilizer spreaders cannot be adapted for compost use and new spreaders may need to be purchased for compost.

Economic Measure iii

Although there were no direct comparisons made in Year 1 of the Green Bin Agriculture Test between municipal compost and chemical fertilizer, there were comparisons made in Year 2 and Year 3. The Complete Yield Chart described in Figure 10 for instance, only compares plots that used compost to those that did not. In Year 2 of the Green Bin Agriculture Test, different combinations of soil amendments were applied to corn on Winchester Research Farm (Brown, 2014, p. 11). The intent was to determine the impact on factors such as: lodging (0-10), moisture $(\%)$, test weight $(\mathrm{kg} / \mathrm{hl})$ and yield (bushels/acre) (p. 11). A table summarizing the yield results for the various treatments can be seen below in Figure 17. Evidently, the $150 \mathrm{lbs} /$ acre N (using urea) treatment was found to have the highest yield at 257 bushels of corn/acre (p. 11).

\begin{tabular}{|l|l|}
\hline \multicolumn{2}{|c|}{2013 Compost on Corn - Winchester Research Farm } \\
\hline Treatment & Yield (bu/ac) \\
\hline 150 lbs/ac N (using urea) & 257 \\
\hline Biosolid pellets + 125 lbs/ac N (urea) & 247 \\
\hline Compost (10 ton/ac) + 150 lbs/ac N (urea) & 235 \\
\hline Compost (10 ton/ac) + 75 lbs/ac N (urea) & 241 \\
\hline (20 ton/ac) compost & 182 \\
\hline No compost, pellets or N fertilizer & 157 \\
\hline
\end{tabular}

Figure 17: 2013 Compost on Corn - Winchester Research Farm (Brown, 2014, p. 11).

In contrast, the treatment of (20 ton/acre) compost, yielded 182 bushels/acre (p. 11). However, the treatment of compost (10 ton/acre) in combination with $150 \mathrm{lbs} /$ acre $\mathrm{N}$ (urea) produced 235 bushels/acre (p. 11). Notably, a similar compost treatment that reduced the $\mathrm{N}$ urea to $75 \mathrm{lbs} / \mathrm{acre}$ grew 241 bushels/acre (p. 11).

Comparable tests were done at the Strathroy site and Strathmere Lodge site which used varying amounts of compost on plots of corn and soybeans (p. 13, 15). The results for the 
Strathroy site showed a higher yield on plots that had compost applied to them over plots that used none (p. 13). However, in comparing plots with larger and larger quantities of compost, the increases in yield were found to only continue to a certain point of application with the ideal of $\sim 5,000 \mathrm{lbs}$ of organic matter being achieved from a 6.5 ton rate (p. 13). The soil was also seen to be healthier after an application of compost as the $\mathrm{CO}_{2}$ increase indicated more microbial respiration (p. 14). At Strathmere Lodge, various treatments of compost were compared in terms of yield (bushels/acre) and profit for corn (p. 15). There were short plots planted in April and long plots planted in June (p. 15). Another comparison made at Strathmere Lodge was between first cut yields (dry ton/ac) on a forage with various combinations of fertilizer, compost and pellets which can be viewed below in Figure 18 (p. 16).

\begin{tabular}{|l|l|}
\hline \multicolumn{2}{|c|}{ Compost on Forages (Peel Region Compost) } \\
\hline Treatment & 1st Cut Yield (dry ton/ac) \\
\hline Fertilizer & 1.67 \\
\hline Compost & 1.68 \\
\hline Pellets & 1.68 \\
\hline Fertilizer + pellets & 1.63 \\
\hline Pellets + compost & 1.70 \\
\hline Fertiliser + compost & 1.78 \\
\hline Pellets + compost + fertilizer & 1.87 \\
\hline
\end{tabular}

Figure 18: Compost on Forages (Peel Region Compost) (Brown, 2014, p. 16).

Based on the results, the pellets + compost + fertilizer treatment had the highest yields at 1.87 dry ton/ace (p. 16). Of the three individual treatments, compost and pellets tied at 1.68 dry ton/acre while fertilizer came in at 1.67 dry ton/acre (p. 16). Last, various applications of compost were used on strawberries, the first horticultural crops to undergo the trials at the Thames Centre site (p. 25). The yield summary reports an increase in yield by $23 \%$ with a treatment of only compost (p. 29).

\subsubsection{Economic Criterion: Is There Enough Supply and Demand?}

Once it has been established that compost use is feasible, determining whether there is a market present for the product is vital, as is understanding the supply and demand model it follows. Consequently, the third Economic Criterion asks whether there is enough supply and demand, which is a question aimed at the ROP. Although the needs of the market may be 
constantly changing, the ROP needs to be able to adapt to them if they want a share of the market. Moreover, given a thorough understanding, the ROP may be able to impact the demand through advertising and respond to supply needs.

\begin{tabular}{|c|c|c|c|}
\hline \multicolumn{4}{|c|}{ Economic Criterion 3} \\
\hline $\begin{array}{c}\text { Category of } \\
\text { Sustainability }\end{array}$ & Criterion & & Measure \\
\hline Economic & $\begin{array}{l}\text { Is there enough supply } \\
\text { and demand? }\end{array}$ & & $\begin{array}{l}\text { Can demand be created? Can supply } \\
\text { be increased? Can we balance them? } \\
\text { What does the marketing campaign } \\
\text { involve? (Are there physical } \\
\text { advertisements available, information } \\
\text { online, information sessions?). } \\
\text { How far reaching is the marketing in } \\
\text { regard to the Region of Peel } \\
\text { residents? }\end{array}$ \\
\hline
\end{tabular}

Figure 19: Economic Criterion 3.

Therefore, this section will discuss whether supply and demand can be created or balanced, what the ROP marketing campaign encompasses, and whether the marketing strategies reach the ROP's residents. All three topics can be viewed above in the Measures column of in Figure 19.

Economic Measure i

In Canada, compost supply and demand is seasonal due to the long and cold winters experienced in this country. Not only is there nothing growing during this time but any compost gathered will take longer and have a more difficult time decomposing. In fact, there are various types of bacteria that are responsible for the composting process including psychrophiles, mesophiles and thermophiles (Campbell, 1975, p. 16). Each bacteria has a certain temperature range they thrive at naturally (i.e. thermophiles between 100 and $160^{\circ} \mathrm{F}$ ) and that is necessary for the organics to decompose properly into useable compost (p. 18). Although not impossible, these temperatures are more difficult to achieve in the winter and as a result, the ROP only sells compost from April to October (Region of Peel, 2015c).

Demand for compost can be enhanced through advertisements although this is not guaranteed. Education can also be beneficial if the general public is not aware of common uses for the product being advertised. In regards to farmers, the Green Bin Agriculture Test allows them to get involved and provides the opportunity to use compost on trial plots. Supply can be 
increased by escalating the amount of organics collected and thus the amount of compost produced. It is worth mentioning that the ROP is looking to improve its organics collection services for apartment buildings in 2016 (L. Conrad, personal communication, October 15, 2015) which will result in more compost being collected. Similarly, the addition of the AD facility will allow the municipality to provide compost throughout the year and increase the rate of output. Balance is achieved when the price and demand for a product are stable. The ROP has seemingly already achieved this as the price for compost is the same every year. Notably, the price was set to be competitive with similar soil enrichment products while the operation of the program is funded from the tax base revenue (L. Conrad, personal communication, April 23, 2016). Moreover, the demand is unlikely to vary beyond the seasonal. In terms of competition from other retailers, this could change depending on whether they are willing to experiment with their prices to gather customers. To advertise to farmers in particular, the compost needs to be promoted by providing incentives and partnering with farmer co-ops to publicize outside of the ROP.

\section{$\underline{\text { Economic Measure ii }}$}

An assessment of the ROP's marketing campaign indicates the inclusion of both physical advertisements and information online. Physical advertisements include the posters present at local CRCs that indicate to residents when the compost is available and the compost advertisements that decorate ROP vehicles (Conrad, 2012, p. 14). On the homepage of the ROP's official website, compost is not explicitly advertised however, it is indicated in the compost section that compost can be purchased at your local CRC (Region of Peel, 2015c). A price for the compost is stated and a number to call for more information is provided (2015c). On the other hand, there does not appear to be regular information sessions available for residents in the ROP. There are a power points available online, however these meetings do not seem to be open to the general public. A number of these presentations do concern and involve local farmers such as the Peel Soil and Crop Field Day which had a compost spreader demonstration (Conrad, 2012, p. 27-29). On a different note, the Compost Council of Canada (2010a) provides information for conferences, workshops and webinars regarding compost. Similarly, the Ontario Federation of Agriculture (2016) provides a calendar of events related to agriculture such as Farm shows, XPOs and meetings but both of these sources are independent of the ROP. Consider that from 
the in-person interviews, two "non-participating" farmers indicated they were familiar with the Green Bin Agriculture Test while ten reported they were not. This indicates there is a need to increase communication concerning information sessions and advertising for ROP programs.

\section{Economic Measure iii}

The ROP's marketing strategy which focuses on physical advertisements and information online is sufficient considering the limited compost output but will need to be improved. For instance, the posters present at local CRCs are only seen by residents who are already visiting the centre. This minimizes the opportunity to bring in potential customers for compost.

Contrastingly, the advertisements that decorate ROP vehicles can potentially be seen by anyone who drives depending on the size of fleet. As previously indicated, the ROP varies between low density towns and high density cities. The Town of Caledon is low density with a population of 58, 000 people and an area of 700 square kilometres (Town of Caledon, n.d.). Unsurprisingly, the main mode of transportation in the Town of Caledon is private vehicles such as cars as there is no public transportation. In contrast, the City of Brampton and the City of Mississauga are of higher density with populations of 600,000 and 729,000 respectively (City of Brampton, 2015; Mississauga, 2015). While public transportation is available at both of these locations, the private vehicle is still a prevalent means of transportation thus indicating ROP vehicle advertisement is beneficial.

Other means of advertising such as large billboards strategically placed by main roads would be advantageous to Caledon farmers. Overall, advertising compost though the various flyers and information brochures seems like the best option. The ROP already sends out these communications to residents on a yearly basis to assist in properly sorting waste and detail the collection schedules. Similarly, the official ROP website should advertise compost on the home page with an image of the poster available at CRCs rather than mentioning it briefly in text. At present, only residents who are specifically inclined to search for information on compost will find it thus failing to inform residents. However, by advertising the compost and making it more prominent, it will be more likely to be noticed by potential customers. The ROP needs to determine a strategic direction for their marketing since there may not be enough of the product for large scale operations. 


\subsection{Social Category of Sustainability}

An important perspective is provided by the Social Category of Sustainability as it considers the residents of the ROP and their role in the Green Bin program. The ROP residents are not only buying municipal compost but also contributing to the Green Bin program through their organic waste and benefiting from the collection services. Ultimately, both the ROP and its residents are responsible for the success of the organics program. However, the ROP has the additional role to its residents. This includes ensuring access to the Green Bin program, equitable pricing options and public awareness/educational campaigns. Figure 20 highlights the approaches that will be discussed for the ROP to ensure participation and inclusiveness for its residents.

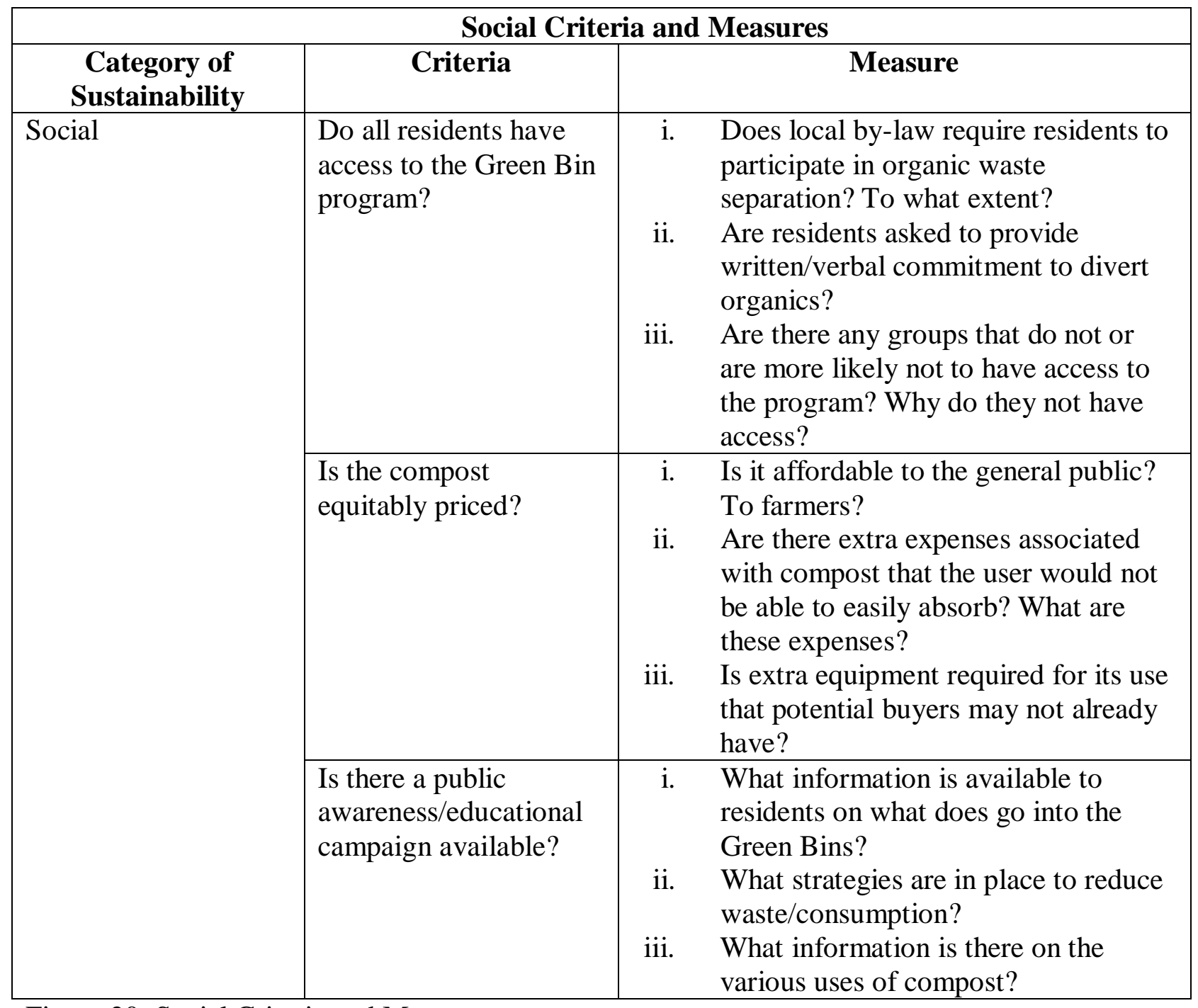

Figure 20: Social Criteria and Measures. 


\subsubsection{Social Criterion: Do All Residents Have Equal Access to the Green Bin Program?}

As in other municipalities, the waste collection services provided on behalf of the ROP are funded by the taxes that are paid by residents. As a result, these services should be equally accessible to all residents and further, it is the responsibility of the municipality to ensure this. Briefly, the necessity of resident access regardless of location, poverty level or even building type will be discussed in this section. However, it is also the responsibility of residents to participate in these programs in accordance with the guidelines set out by the ROP or alternatively, take responsibility for the disposal of their own waste. With this in mind, the first step to determining whether there is equal access is to analyze the local by-law. In particular, whether or not the by-law states that residents are required to participate. The next step expands on this by asking whether residents have to provide written/verbal commitment to divert organics. These Measures can be seen in Figure 21 below.

\begin{tabular}{|l|l|ll|}
\hline \multicolumn{1}{|c|}{$\begin{array}{c}\text { Category of } \\
\text { Sustainability }\end{array}$} & \multicolumn{1}{|c|}{ Criterion } & \multicolumn{1}{c|}{ Measure } \\
\hline Social & $\begin{array}{l}\text { Do all residents have } \\
\text { access to the Green Bin } \\
\text { program? }\end{array}$ & i. & $\begin{array}{l}\text { Does local by-law require residents to } \\
\text { participate in organic waste } \\
\text { separation? To what extent? }\end{array}$ \\
& ii. $\begin{array}{l}\text { Are residents asked to provide } \\
\text { written/verbal commitment to divert } \\
\text { organics? }\end{array}$ \\
& Are there any groups that do not or \\
& are more likely not to have access to \\
& & $\begin{array}{l}\text { iii. } \\
\text { the program? Why do they not have } \\
\text { access? }\end{array}$ \\
\hline
\end{tabular}

Figure 21: Social Criterion 1.

However, it is the third Measure, which deals specifically with a lack of resident access and questions whether there are any groups that do not or are more likely not to have access to the program.

\section{$\underline{\text { Social Measure i }}$}

In the ROP there are a number of by-laws on topics pertaining to: traffic, smoking in public locations, requirements for calling council meetings and wastewater (Region of Peel, n.d. a). However, the Waste Collection By-Law 35-2015 which regulates waste in the ROP provides answers on resident participation in organic waste separation (The Regional Municipality of 
Peel, 2015). The document begins by defining a number of its terms and outlining the waste collection service and its limitations, exemptions, placement on the curbside, time restrictions, frequency of collection and on-site waste collection (2015). Section 5, Non-Complying Waste is the most relevant as it states, "5.1 No Occupier/Owner shall Set Out Non-Complying Waste either on its own or mixed with any Waste" and "5.2 The Region or its agents shall not collect Non-Complying Waste" (2015). It is apparent from section 5.1 that the ROP is concerned about dangerous waste or waste being sorted improperly and as a result, section 5.2 clarifies that the waste will not be collected if there is "non-complying waste" (2015). The ROP indicated earlier in section 3.5a) that garbage carts will be collected once every two weeks from Residential Units and Multi-residential Complexes (2015). These sections indicate to the reader that collection services are made available to residents in the ROP but to participate, residents are required to sort their waste or the material will not be collected. Further requirements are mentioned in Section 6 concerning receptacle requirements for garbage, recycling, organics and yard waste (2015). In addition, conditions for waste collection are outlined in Section 7 (2015). Last, Section 15 Enforcement describes the circumstances a resident may receive a notice for failing to comply with the by-law (2015). In the event of non-compliance, the individual will pay the cost of "clean-up" as outlined in section 15.4:

15.4 Where a person does not comply with a notice issued pursuant to subsection 15.3, the Commissioner may perform or carry out that which is required to be done or cause it to be performed or carried out at that person's expense. (2015)

Notably, the by-law also discusses alternate options of waste disposal for HHW and special waste via CRCs in section 7.18 (2015). CRCs allow residents to dispose of additional waste and items that would not be collected as a part of the bi-weekly collection (Region of Peel, 2015d). However, certain materials (e.g., building materials) for drop-off are chargeable based on weight (2015d). To conclude, ROP by-laws encourage residents to participate in waste collection and the separation of materials. Moreover, there are negative consequences for not using approved containers and for not separating waste, organics, and recyclables. The approved containers and the bi-weekly pick-up regulates the amount of waste and forces the residents to separate it into three bins or else they would quickly run out of space in the garbage cart. The ROP has taken a 
pro-active approach by providing tools for the residents to be successful rather than focusing on non-compliance.

\section{$\underline{\text { Social Measure ii }}$}

There is no written or verbal commitment to divert organics described in the ROP's Waste Collection By-Law 35-2015. As discussed in the previous Measure, it is only strongly encouraged to separate organics and waste materials and if done improperly, the ROP may refuse collection (The Regional Municipality of Peel, 2015). Moreover, residents may receive a notice after failing to comply and if ignored, further action will be taken on by the Commissioner (2015). According to the by-law, these are the only methods the ROP uses to ensure compliance by residents. Furthermore, this by-law is the most relevant document for waste collection services available to residents and since it does not mention or even redirect readers to other sources for more information, it is unlikely other sources will discuss this topic to a significant degree. Based on the approach taken by the ROP it can be said that the municipality is giving residents the opportunity to be environmentally friendly and to feel good about their contribution. This approach is heavily reliant on social conformity which plays an important role in public participation but is often not enough on its own.

\section{$\underline{\text { Social Measure iii }}$}

A key component of a successful waste collection program is its ability to service the entirety of its residents. The ROP's waste management goal of 75\% (Boughton, 2015) will be more easily achieved if all residents are included. Determining who is included in residential collection is an important first step. In the Waste Collection By-Law 35-2015, section 3.8 Frequency of Source Separated Organics Collection Service it is stated that, "(a) The Region shall collect Source Separated Organics no more than once per week from Residential Units and Multi-residential Complexes that receive Curbside Collection on the Scheduled Collection Day or as approved by the Commissioner" (2015). From this passage it is apparent that the ROP's current collection services extend to: Residential Units and Multi-residential Complexes (2015). According to the by-law, a Residential-Unit may refer to: a) single-detached residences, b) semidetached residences, c) unit duplexes, triplexes, four-plexes, five-plexes or six-plexes and, d) units of apartment buildings, condominium complexes, townhouse complexes and co-op complexes (2015). However, this does not include: hotels, motels, restaurants or an Accessory 
Dwelling Unit (2015). On the other hand, Multi-residential Complexes include: apartment buildings, condominium complexes, townhouse complexes, co-op complexes and Licensed Lodging Houses (2015). For both, Residential Units and Multi-residential Complexes other similar residential complexes that contain six or fewer Dwelling Units are included (2015).

Based on these definitions of Residential Units and Multi-residential Complexes, the organics collection program is quite inclusive of the various residential dwellings in the ROP. As previously stated, there is quite a deviation between low density towns such as Caledon and high density cities like Brampton and Mississauga despite the average density being 1,040.0 people per square kilometre (Statistics Canada, 2015). In particular, Caledon has a high amount of farm land and ecologically significant areas such as the Forks of the Credit River which impact the types of residences that are built. Contrastingly, Brampton and Mississauga are constantly expanding outward and will likely have to build up their density in the future. Despite the inclusiveness of the residences serviced, institutions such as: schools, hospitals, restaurants and, businesses are not mentioned in the by-law as serviced for organics collection. It is assumed that as these are institutions rather than residences, they are expected to take care of their own waste materials. This is confirmed in section 10 Industrial, Commercial or Institutional Waste of the Waste Collection By-Law 35-2015 which states, "10.1 All persons involved in the creation of Industrial, Commercial or Institutional Waste shall make provision for on-site, private Waste removal unless another provision has been made with the Commissioner" (The Regional Municipality of Peel, 2015). Clearly, it is not just institutions that are expected to deal with their own waste removal but industrial and commercial properties as well (2015). Although there are mentions of waste and recycling collection for institutions in section 3.5 and 3.6 respectively, this applies only under the circumstance that they receive front-end collection on the scheduled day as approved by the Commissioner (2015). To conclude, there are no residence accommodations in particular that are lacking organics collection services except for a few building types that are likely expected to be responsible for their own wastes (i.e. hotels, motels, restaurants etc.) (2015). Additionally, institutions, industries and commercial properties are, as stated in the by-law, explicitly expected to take responsibility for their own waste removal (2015). Hospitals, hotels and restaurants are expected to have a large amount of organic waste. 


\subsubsection{Social Criterion: Is the Compost Equitably Priced?}

The second Social Criterion is deceptively simple by asking: "Is the Compost Equitably Priced?" The challenge of defining what is equitable pricing is the first step; however, there are also various parties to consider and additional costs associated with the compost. For instance, residents of the ROP are charged 3.5ф per kg or $\$ 35$ per tonne for a very fine garden-specific compost (Region of Peel, 2015c). On the other hand, farmers pay \$5-7 per tonne to farmers for a compost that is more rough and agriculture-specific (Brown, 2014, p. 32). Evidently, these two situations are not comparable and each user will potentially have their own limitations for compost price.

\begin{tabular}{|c|c|c|c|}
\hline \multicolumn{4}{|c|}{ Social Criterion 2} \\
\hline $\begin{array}{c}\text { Category of } \\
\text { Sustainability }\end{array}$ & Criterion & & Measure \\
\hline Social & $\begin{array}{l}\text { Is the compost } \\
\text { equitably priced? }\end{array}$ & & $\begin{array}{l}\text { Is it affordable to the general public? } \\
\text { To farmers? } \\
\text { Are there extra expenses associated } \\
\text { with compost that the user would not } \\
\text { be able to easily absorb? What are } \\
\text { these expenses? } \\
\text { Is extra equipment required for its use } \\
\text { that potential buyers may not already } \\
\text { have? }\end{array}$ \\
\hline
\end{tabular}

Figure 22: Social Criterion 2.

Once an equitable pricing range has been established for both groups, it can be determined whether municipal compost is affordable to the general public and to the farmers. However, there is also a set of additional expenses in the form of transportation and application costs that will likely require the purchasing of tools or other equipment. Therefore, the extra expenses associated with compost for each group will be determined and whether there is any extra equipment required. Above, Figure 22 details the Criterion and the three accompanying Measures that discuss these topics.

\section{$\underline{\text { Social Measure i }}$}

The ROP sells compost to residents at a price of 3.5ф per $\mathrm{kg}$ or $\$ 35$ per tonne from April to October (Region of Peel, 2015c). In order to determine whether the price is equitable, comparisons were made to other similar products that can be found at garden centres in Home 
Depot, Walmart and Lowe's. The products had to be comparable in terms of content (i.e. compost made from food scraps and/or yard waste) and intended for the home garden. A single "best priced" product was chosen from each retailer to compare to the ROP. Home Depot sells Premier Mushroom Compost for \$3.99 for 30lbs (Home Depot, 2016). In other words, this product is sold for $29 \varnothing$ per $\mathrm{kg}$ which is notably more expensive than the ROP product. Walmart sells Premier Potting Soil for $\$ 3.47$ for $17 \mathrm{lbs}$ (Walmart, 2016). At a price of $45 \not$ per $\mathrm{kg}$, this product is more expensive than even the Home Depot product. Lowe's sells Scotts 20lb Pro Blends $^{\text {TM }}$ 3-in-1 Pre-Mixed Topsoil for $\$ 2.99$ for 20lbs (Lowe's, 2016). This product is also more expensive than the ROP's compost at $32 \varnothing$ per $\mathrm{kg}$. With a range of pricing from $29 \phi$ to $45 \phi$, the ROP's compost is priced "dirt cheap" at 3.5ф. In fact, a quick calculation establishes that the mean of the three prices is $35 \varnothing$ as seen below.

Mean $=0.29+0.45+0.32 / 4$

$=0.35$ or $35 \phi$

The ROP's compost price is easily the lowest and arguably affordable considering the range of retail prices. This is not including other compost products sold such as manure and chemical fertilizers. The typical consumer for municipal compost would be gardeners or small nurseries as they require a small amount of compost at a reasonable price that is comparable to packaged products at large retailers. It is also important to consider that municipal compost can be regarded as the environmental choice by consumers as no packaging is used, the product is produced locally and in compliance with national and provincial regulations.

In regards to the affordability to farmers, the ROP compost product was previously compared to the Holmes Agro products of urea, MAP and potash. A calculation determined that the former was less expensive to apply per acre but the transportation cost and the cost of spreading in terms of equipment and labour provided a major challenge for farmers. As a result, the ROP product is at a disadvantage despite its lower cost.

\section{$\underline{\text { Social Measure ii }}$}

The expenses associated with compost use are very different for residents and farmers of the ROP. While both have to purchase said product, to transport it home and apply it, the tools necessary to achieve this add up. While residents pay $3.5 \varnothing$ per $\mathrm{kg}$ or $\$ 35$ per tonne, they are expected to bring their own bin and shovel (Region of Peel, 2015c). This "bin" can be the size of 
a box or a trailer depending on the amount of compost the resident intends to purchase. However, it can be assumed that a resident who is not already in possession of a trailer and wishes to purchase a large amount of compost will either rent (\$34/day) or borrow one from a relative or friend. Shovels can be purchased inexpensively (\$15-30) and it is understood that most people are already in possession of one especially if they own a home garden. Once brought home, the compost can be manually spread with a shovel and a rake.

In contrast, the farmers in the ROP pay \$5-7 per tonne for compost that is specifically intended for agriculture (Brown, 2014, p. 32). The compost is loaded on a truck and transported home by the farmer which eliminates the need for bins or shovels. Notably, in both situations the transportation expenses vary with distance (p. 32) and as a result it is difficult to provide calculations. However, a farmer will require a larger volume of compost to cover their fields which will likely require multiple truck loads depending on the acreage and thickness of application. This expense is reflected in the interviews where transportation costs came up repeatedly as a concern. Indeed, compost was stated to be difficult to transport compared to chemical fertilizer by the Green Bin Agriculture Test as the same amount of compost requires more trips (p. 32). On the other hand, the compost only needs to be applied once every several years thus reducing the expense for farmers. The same can be said for residents who likely only use compost in small amounts at the start of the growing season. Notably, the resident's vehicles will use slightly more gas during transport due to the extra weight of the compost which could constitute an additional expense but is usually easily absorbed. Similarly, farmers are responsible for their own transportation in regards to compost.

\section{$\underline{\text { Social Measure iii }}$}

As indicated above, any extra equipment residents may need during the compost acquisition and transportation phases can be purchased and re-used or even rented. In terms of applying the compost, this will require tools such as a shovel and if desired, gardening gloves (\$5) and a wheelbarrow (\$30). The exact expenses vary depending on the willingness of the resident to purchase and experiment with different gardening tools. Consider, compost use by residents is usually in pursuit of a hobby or the desire to grow their own fresh produce.

Dissimilarly, farmers in the business of agriculture aim to make a living from farming. As a result, the scale needed to achieve this is much greater as is the accompanying equipment. The 
large machine necessary to distribute the compost on the field is called a "spreader" which is expensive to buy, use and maintain in proper working order. In fact, several farmers indicated during the interviews that they were a part of a co-op and benefited from the shared equipment and ability purchase expensive machinery that they would otherwise not be able to afford. Incidentally, several farmers expressed the concern that young people were not interested in farming due to barriers such as a lack of education about farming and the daunting expenses associated with the business.

\subsubsection{Social Criterion: Is There a Public Awareness/Educational Campaign Available?}

Although the ROP is achieving its goals by diverting waste from landfills and even increasing its 3Rs target to $75 \%$ by 2034 (Boughton, 2015) the education and awareness of residents is an important factor. The third Social Criterion asks: "Is There a Public Awareness/Educational Campaign Available?" This can include a number of topics related to the Green Bin program. For instance, determining what information is available to residents in regards to what goes into the Green Bins and what strategies are offered to reduce waste/consumption are an important element. The first is necessary for the Green Bin program to be implemented effectively while the second ultimately helps to reduce the amount of waste materials to be land filled. Both Measures can be viewed below in Figure 23.

\begin{tabular}{|l|l|ll|}
\hline \multicolumn{1}{|c|}{$\begin{array}{c}\text { Category of } \\
\text { Sustainability }\end{array}$} & \multicolumn{1}{|c|}{ Criterion } & \multicolumn{1}{c|}{ Measure } \\
\hline Social & $\begin{array}{l}\text { Is there a public } \\
\text { awareness/educational } \\
\text { campaign available? }\end{array}$ & $\begin{array}{l}\text { i. } \\
\text { What information is available to } \\
\text { residents on what does go into the } \\
\text { Green Bins? }\end{array}$ \\
& ii. $\begin{array}{l}\text { What strategies are in place to reduce } \\
\text { Waste/consumption? }\end{array}$ \\
& iii. $\begin{array}{l}\text { What information is there on the } \\
\text { various uses of compost? }\end{array}$ \\
\hline
\end{tabular}

Figure 23: Social Criterion 3.

The third enquiry considers the information present on the various uses of compost. Residents will not be interested in ROP compost if they are unaware of its uses and the benefits to the soil. The awareness/educational campaign plays a major role in establishing this base knowledge and advertising compost to the residents. 


\section{$\underline{\text { Social Measure i }}$}

The Green Bin program relies heavily on the ability of ROP residents to properly sort their waste material. Therefore, the information available to residents must be readily available, accurate and complete. In terms of sources of information, there are: hard copies, online information, and phone numbers for further inquiries. Hard copy information includes a Waste Collection Calendar and the Region of Peel 2014/2015 Waste Management Guide. The Waste Collection Calendar is provided yearly to residents and indicates the collection schedule for organics, yard waste and other curb-side collection materials. A fridge magnet titled "What Goes into the Green Bins?" is included. It details various acceptable food wastes (i.e. baked goods, bones, cereal), paper products (i.e. cotton balls, facial tissue, pizza boxes) and other items (i.e. hair, house plants, pet fur) that can go in the Green Bin with green text. Non-acceptable items (i.e. aluminum foil, bandages, cigarette butts or ashes) are also listed and are written in red. The ROP website and a phone number are listed below to pursue further information. Additionally, the Region of Peel 2014/2015 Waste Management Guide is a booklet provided to residents that mostly details all the waste collection schedules for the various neighbourhoods in the ROP. However, other information is included such as container size limitations (p. 7), helpful hints for using your Green Bin (p. 10) and about the yard waste program (p. 15) and, acceptable Green Bin items (p. 11). The latter of which uses pictures to indicate what items are acceptable and provides a website for further inquiry (p. 11).

By its nature, on-line information is more difficult to comprehend than hard copy information as there is an endless number of resources available to users that may be incorrect or even conflicting. For the purpose of this paper, the official ROP waste management website will be the main reference point. On the ROP website, residents can enter the names of waste items in a search bar to learn how to properly dispose of them (Region of Peel, 2015g). Residents can also find additional information by bin type (2015g). The Organics bin information gives a brief rundown of acceptable items (Region of Peel, 2015h). Available for download is the Organics (Green) Cart Owner's Manual which gives residents an idea of how to sort their organic waste (p. 6-7). There is also information on how to set out a Green Bin properly (p. 4) and other services (p. 11). The Yard Waste information includes a list of acceptable yard waste items such as tree trimmings, branches and grass clippings (Region of Peel, 2015i). Finally, phone numbers for 
further inquiries have been provided online for residents who may have additional questions. Clearly, the ROP is providing a decent range of resources for its residents in order to educate themselves on the sorting of organic waste. Whether or not these materials reach the residents, is a concern that is not covered in this paper.

\section{$\underline{\text { Social Measure ii }}$}

The ROP has waste reduction built into its waste management plan with the LTWRMS and the 4Rs of the Waste Management Hierarchy: Reduce, Reuse, Recycle and Recover (Region of Peel, 2015a). This is implemented through curb-side collection for grey bins, blue bins and green bins (Region of Peel, 2015b). Meanwhile, the Waste Collection By-Law 35-2015 enforces the separation of waste materials through section 5.2 which indicates that the ROP will not collect "non-complying" waste (The Regional Municipality of Peel, 2015). Further, the cartbased, bi-weekly collection that was implemented in January 4th, 2016 is also contributes to the waste reduction strategy (Region of Peel, 2015b). The movement towards bi-weekly collection forces residents to carefully manage their waste output and properly sort their recyclables and organics without going beyond the limitations of the cart. Notably, residents can buy garbage tags to put on excess garbage bags at the curb-side (Region of Peel, 2015j). The garbage tags can be bought at CRCs for a price of five tags for \$5 (2015j). Additionally, CRCs provide waste management services for residents and even operate a Re-Usable Goods Drop-Off Area which accepts items in reasonable working condition (Region of Peel, 2015d). In short, the ROP provides the necessary services for residents in a way that encourages them to reduce their waste and by association, their consumption.

In terms of educational strategies to reduce waste, the ROP provides a variety of media to get their message across including pamphlets such as the Region of Peel 2014/15 Waste Management Guide and online websites like the official ROP website. Both place a noticeable emphasis on educating residents on how to properly sort their waste; however, there seems to be a lack of education on reducing consumption. For instance, there is no mention of limiting general waste through reducing consumption, litter prevention or limiting food waste by careful meal planning, crop sharing and backyard composting. This is reflected in the ROP goal to increase waste diversion $75 \%$ by 2034 which does not seem to involve residents beyond being informed of and participating in the waste management programs (Boughton, 2015). 


\section{Social Measure iii}

An important part of selling a product is communicating to the consumer the various uses for that product. In the case of municipal compost, this is essential to ensure that the consumer is educated regarding the common uses and knows how to properly apply the product. Coincidentally, compost has several uses beyond that of gardening. Compost is a soil amendment that is used for plant production-related industries such as: commercial greenhouse productions, farms, landscapers, and turf and land remediation (Cooperband, 2002, p. 1). It replaces peat and topsoil as seed starters, container mixes, soil amendments, mulches and natural fertilizers (p. 1). As a soil amendment, it contains a variety of nutrients including nitrogen, phosphorus and potassium which contribute to the health of the soil (Compost Council of Canada, 2010b). It also improves the soil structure, aeration and water retention and is beneficial for erosion control and roadside landscaping (2010b). Even low grade compost is beneficial as a landfill cover or in land reclamation projects (2010b). The availability of information on compost and its uses was evaluated through the media utilized by the ROP.

Compost is promoted in the Region of Peel 2014/2015 Waste Management Guide, on the ROP website, the compost label and an advertising campaign. In the Waste Management Guide it is mentioned that finished compost can be bought at CRCs seasonally and consumers should bring their own reusable containers (p. 19). No information about compost use is provided. On the ROP website, there is a section that concerns compost but no information pertaining to the uses of compost are available (Region of Peel, 2015c). The compost label informs the reader about the proper compost application rate and application thickness, among other types of advice but does not expand on uses for the compost. However, the Ontario Compost Quality Standards (July 25, 2012) which is referenced by the compost label, categorizes compost as Category AA, Category A or Category B in order to guide users (Ministry of the Environment, 2012, p. 11). Last, the advertising campaign involves large signs posted at the various CRCs in the ROP that indicate compost is available for sale. There are also certain ROP vehicles that have an advertisement for the compost on the body of the vehicle. However, neither of these mention potential uses for the compost. In summary, the ROP does not provide information on the various uses of compost in any of the assessed promotional material. This may reflect the belief that compost is common knowledge or that anyone that would have an interest in compost would 
already be knowledgeable. Regardless, any potential users would have to look to sources outside of the ROP to find more information. Overall, the composting marketing strategy was found to be passive with the onus on the consumer to education her/himself.

\subsection{DISCUSSION/RESULTS}

In this section, a discussion of the results for all three Categories of Sustainability will be facilitated. The major points previously brought up in the results section will be discussed in relation to achieving environmental, economic and social sustainability. Moreover, the results will be discussed in context to the Green Bin program and the reality for the ROP.

\subsection{Discussion of Environmental Results}

The initial concern, whether the organic waste collected as a part of the Green Bin program is being re-purposed provided a starting point for determining environmental sustainability. It was established that based on the amount of organics collected in the year 2014 $(29,853.92$ tonnes), and the amount of organics sold (12,410 tonnes), the majority of organic waste is being sold as compost (L. Conrad, personal communication, October 15, 2015). The remaining compost for that year was either sent to a third party (3,705 tonnes) or to a mine project (4,067 tonnes) (L. Conrad, personal communication, October 15, 2015). Although the collection and sales numbers are notably different, consider that the ROP sorts the collected organics to remove contaminants and the organics themselves naturally decrease to $40-60 \%$ of their original volume during the composting process (Martin, 2005, p.1). These numbers indicate that the organic waste collected is being processed as compost products and re-purposed. On a broader scale, the ROP has a waste diversion goal that is aided by the Green Bin program. The ROP recently increased its waste diversion target to $75 \%$ by 2034 from $70 \%$ by 2016 indicating success with the previous diversion target (Boughton, 2015). It is evident that the Green Bin program played an important role in this achievement due to the emphasis placed on future improvements for the program such as the inclusion of new items for collection (e.g., diapers, sanitary products, and pet waste) (2015). Similarly, the Green Bin Agriculture Test is intended to provide scientific evidence to support the Green Bin program. While the goal of the trials is to determine the long-term impacts of compost and the benefits for agriculture (Region of Peel, 
2015e) the study could potentially result in the emergence of a new market for compost sales. Overall, the trials indicated compost had a beneficial impact on yield which improves customer satisfaction and the involvement of farmers provides a new customer base. Clearly, there is experimentation occurring with new programs and an attempt to expand the market for compost indicating the ROP's future intentions for organics collections. Notably, all of the statistics discussed in this study are available from or provided by the ROP and OMAFRA. Moreover, there are no quantitative data available to the public to compare the organics collection and sales statistics from year to year.

Arguably, the composition of the compost and ensuring the absence of harmful chemicals is as important as diverting waste from landfills and providing collection services to residents. Although a soil analysis of the ROP compost product is beyond the scope of this study, an inquiry into compliance with the government and industry regulations and determining if there is a written guarantee of quality was undertaken. It was established that there is a guarantee of quality in the form of a compost label which describes the composting process, the proper compost application and thickness rate and provides a warning for use on certain soils. Further, an affiliation with the Compost Quality Alliance is indicated which is a voluntary industry initiative that goes above and beyond the minimum Ontario standards for compost written by the CCME (2005). The ROP successfully adheres to both of these requirements as it is understood that membership to the Compost Quality Alliance is on-going and the national and provincial regulations prevent compost from being sold if it fails to meet their standards. However, the presence of these regulations will not necessarily prevent misinformation among residents concerning the potential for harmful chemicals in the compost. The ROP's strategy for advertising and informing residents about compost include the flyers and booklets residents receive with their Green Bins, the ROP website and the compost label. Although it was determined that there is ample information pertaining to the proper sorting of waste in these sources, there is a lack of information about potential harmful chemicals. The only reference found is in the compost label which redirects readers to provincial and national guidelines. Notably, the compost label was attained by sending out an email to the ROP concerning compost quality and does not appear to be widely available in paper format or online. An informative flyer that discusses similar information to the compost label is available to residents at CRCs 
upon request only. Interestingly, a small number of the farmers interviewed who self-identified as "organic" would not use the ROP compost for fear of harmful chemicals and metals. As a result, the organic farmer market is currently beyond the capability of the ROP to serve despite compliance with various regulations. However, this can be solved by providing a certified organic option for farmers who require it thus opening the ROP to a new market.

Climate change as a potential environmental externality was examined in relation to the Green Bin Agriculture Test. First, the implementation of a "cap" and "trade" system which requires a government or regulatory agent to set a limit or "cap" on emissions was discussed (Goetz et al., 2009, p. 381). Second, this system provides direction for the future of the Green Bin Agriculture Test, whereas the use the ROP's Green Bin compost in place of chemical fertilizer could potentially save carbon credits due to reduced GHG emission. Practically speaking, compost contributes to both emissions and avoided emissions (Boldrin et al., 2009, p. 800). In a study, it was determined that compost will sequester carbon (which reduces GHGs) by $5,046 \mathrm{~kg} \mathrm{CO}_{2}$ equivalents at an application rate of 10 tonnes DM per hectare over 20 years (Biala, 2011, p. 5). Further calculations established that 197,869 carbon credits would be saved over 20 years if all the agricultural land in the ROP switched to compost. Without sequestration, 6,742 carbon credits would be saved in the same time frame and application rate. However, assigning a value to these numbers via the establishment of a Canadian carbon market is an important step. Moreover, emissions originating from chemical fertilizer production may not be the largest source of GHGs in the agriculture sector and there are likely larger emitters present in other industries such as the transportation sector. This argument is pervasive in global discussion about climate change in regard to laying the blame on certain industry sectors and countries and often prevents climate change action. Despite this, the Green Bin Agriculture Test shows it is important to move forward and focus on the next question: whether this switch is worthwhile for farmers and what would be required to encourage participation.

\subsection{Discussion of Economic Results}

A second apprehension for the is Green Bin program is farmer interest in compost and their willingness to make the switch considering the ROP is looking to expand its production and market backed by the evidence from the Green Bin Agriculture Test. Notably, the presence of a handful of "participating" farmers indicates interest and willingness to consider compost as a soil 
amendment and to potentially make the switch from chemical fertilizer. However, "nonparticipating" farmers which make up the majority are going to be more difficult to reach and convince. The principle soil amendment used by "non-participating" farmers during the interviews was manure, therefore indicating that interest in compost would be minimal. Manure is most commonly used by Beef and Dairy farmers who make up $12.50 \%$ of the farmers interviewed. The next most popular soil amendment is chemical fertilizer followed by compost and green manure which are tied for last at two farmers each. Farmer concerns were also discussed as a part of the interview to provide further insight. Issues that directly impact the profession of farming such as crop yield, competitiveness in the market and climate change or extreme weather were discussed as making the transition to compost difficult especially for farmers who have not used compost before. Concerns discussed that are directly related to compost include the expense of transportation and application, acquiring a large enough amount quickly enough and nutrient deficiency anxieties. In contrast, "participating" farmers were seen to place more emphasis on issues that do not directly impact the farming process such as public misconception and a decrease in farmland. The concern about making a profit was still addressed by this group and the challenge of attaining a large quantity was also voiced and interestingly, compost smell. Overall, more "participating" farmers were seen to be positive about compost use than "non-participating" farmers as they stated a number of benefits. Clearly, there is a distinction between the two groups and successfully gaining the interest of one group will not guarantee that of the other. In fact, in a sample population, the "participating" farmers most likely represents those respondents who are open to innovation and have had positive experience with the agricultural trials and the product. As a result of their willingness to seek out new opportunities, the researcher's random sample may become skewed towards a certain type of person. However, by providing prospects for farmers through information and demonstration sessions and free trials, the ROP will be able to better communicate the value of compost. This occurrence was observed with the "participating" farmers as not all of them had previous experience with compost.

One of the concerns frequently brought up by "non-participating" farmers was the cost of compost. A look into the initial price of municipal compost and the recommended spreadability determined a cost of \$50-70 to cover an acre. Conversely, the Holmes Agro products cost 
between $\$ 110$ to $\$ 137.50$ per acre for urea, $\$ 160$ to $\$ 200$ per acre for MAP and approximately $\$ 105$ to $\$ 131.25$ per acre for potash. Clearly, the ROP product is less expensive; however, as previously stated, there are other cost factors to consider. To start, there's low bulk density of the compost (Brown, 2014, p. 8), the fact that more is needed to achieve the same amount of nutrients as chemical fertilizer and therefore, more transportation and application trips are necessary for the farmer. The cost of spreading was reported by Brown (2014) to amount to \$3-5 per tonne (p. 32). Factors such as distance and acreage however, are incredibly subjective and the farmer's decision to invest in chemical fertilizer or compost will likely be the influenced by their unique situation. This makes changing their stance difficult and often the only way to do so is through experience and education. Hence, the Green Bin Agriculture Test involves farmers in trial plot comparisons with compost and other soil amendments in order to reassure them of the yield. The results for the Strathroy site which used varying amounts of compost on corn and soybeans showed improved yields on plots that had compost applied to them over plots that used none (Brown, 2014, p. 13,15). At Strathmere Lodge various treatments of compost were compared and based on the results, the pellets + compost + fertilizer treatment had the highest yields at 1.87 dry ton/ace (p. 16). Of the three individual treatments, compost and pellets tied at 1.68 dry ton/acre while fertilizer came in at 1.67 dry ton/acre (p. 16). Notably, the direct yield comparisons at the Winchester Research Farm for different soil amendments on corn revealed that a treatment of $150 \mathrm{lbs} /$ acre $\mathrm{N}$ (using urea) had the highest yield at 257 bushels/acre (p. 11). Clearly, compost is better than no soil amendment; however, there is some variation when compared to other soil amendments. Balancing these costs with guaranteed yield potential is important for the farmers and their business to the point that they are unlikely to make the switch without. Only experience and information can change misconceptions.

Finally, the ability of the ROP to cater to the current supply and demand dynamic and to potentially increase both factors was stated to be important for the ROP's sales. For compost, supply and demand was indicated to be seasonal due to the cold winters in Canada. Demand can theoretically be enhanced through advertisements and education provided by the ROP. However, success is heavily dependent on the ability of the municipality to reach its residents with its advertisements. The implementation of both physical advertisements and information online to market the ROP's compost was noted. Physical advertisements include the posters present at 
local CRCs that indicate to residents when the compost is available and the compost advertisements that decorate ROP vehicles (Conrad, 2012, p. 14). On the homepage of the ROP's official website, compost is not explicitly advertised; however, it is indicated in the Compost section that compost can be purchased at a local CRC (Region of Peel, 2015c). There do not appear to be regular information sessions available for residents on compost and if there are, they are not advertised. Overall, it was determined that the ROP's marketing strategy is passive as residents will only find information on compost if they are specifically looking for it. The ROP needs to properly target their audience and determine the best way to reach their demographic. For instance, including advertisements in the various flyers and informative brochures already provided to residents is recommended. Markedly, the ROP was previously stated to be expanding its customer base by providing services to apartments in 2016 (L. Conrad, personal communication, October 15, 2015) and through the empirical support of the Green Bin Agriculture Test. The introduction of an AD facility will allow the ROP to provide compost year round and shorten the composting process. This, coupled with the demographic trends, will change the supply and demand equation if the ROP is successful and require the municipality to balance both the supply and demand appropriately.

\subsection{Discussion of Social Results}

The final investigation involved access to the Green Bin program which, if ensured, benefits the residents by allowing them to appropriately dispose of their waste and participate in waste diversion in a manner that is socially responsible and sustainable. In the ROP, the Waste Collection By-Law 35-2015 is discussed to establish regular collection times for waste, recyclables and organics (The Regional Municipality of Peel, 2015). Evidently, the ROP by-laws encourage residents to participate in waste separation but the municipality retains the right to refuse collection of waste bins that fail to meet their standards (2015). Although there is no written or verbal commitment to divert organics, there are other options for residents to dispose of their waste. As a result of the ROP providing all the information, containers and scheduled pickup for the user, it becomes very convenient for the user as no extra trips or costs are required. With minimal effort required from residents, scraping plates becomes a part of the meal time preparation and consumption routine. Similarly, leaves and grass that would normally be raked and piled on the property now have a designated container. In regard to ensuring complete 
resident access, curbside collection is provided to Residential Units and Multi-residential Complexes (2015). According to the by-law, all residents have access to the Green Bin program and the only building types that are not included are those that are expected to be responsible for their own waste (i.e. hotels, restaurants, institutions, and industries) (2015). Unfortunately, no discussion was made concerning certain groups that may not receive the service (until recently, multi family facilities) or are difficult to service. These groups are not also mentioned in the bylaw as requiring extra consideration and were not mentioned in other documentation.

Providing equitable pricing for the compost product is an important part of access and participation considering residents are partners in the inputting of organics and yard waste. It was established that equitable pricing of Category A garden compost can be determined through a comparison with the soil amendments sold by retail competitors including: Home Depot, Walmart, and Lowe's. The range of pricing provided by these retailers was concluded to be from $29 \varnothing$ to $45 \varnothing$ with the ROP's compost being priced at $3.5 \varnothing$. Clearly, the ROP's compost is comparatively cheap and affordable to residents. In fact, compost is a very small market as it can be assumed the customer is interested in a locally produced organic product. Additionally, it was discussed that the ROP compost costs \$50-70 per acre for farmers. Competitors such as Holmes Agro provide various soil amendments such as urea which costs between $\$ 110$ to $\$ 137.50$ per acre, MAP that costs $\$ 160$ to $\$ 200$ per acre and potash at a cost of $\$ 105$ to $\$ 131.25$ per acre. Although the ROP price for farmers was stated to be less than the competitor's, there are extra expenses associated with the compost that the user would have to consider. On the other hand, farmers need a truck to transport large volumes of compost which would involve multiple trips depending on the size of the farm and compost was stated to be more costly to transport than chemical fertilizer (Brown, 2014, p. 32). Similarly, during application, multiple trips were required with a spreader which was determined to be costly. For the most part, it was assumed that farmers buy compost as a part of their livelihood in an effort to improve their yield. During the interviews, several farmers indicated that the they were a part of a farmer co-op and benefit from shared equipment and the ability to purchase expensive machinery that they would otherwise not be able to afford. Meanwhile, residents who buy compost likely do so in pursuit of a hobby or the desire to grow fresh produce. 
Lastly, a public awareness/educational campaign benefits not only the residents but the ROP as well. In particular, it can help with issues previously discussed such as access and pricing through awareness and involvement. To begin, information available to residents was indicated to come in the form of hard copies, online information, and phone numbers for further inquiries. The hard copy information such as the Waste Collection Calendar and the Region of Peel 2014/2015 Waste Management Guide was stated to include information on sorting organics and yard waste. Notably, the online information explored was on the ROP's website which provided similar information as did the phone numbers for further inquiries. There were no concerns about this information as it was available to residents through a variety of media and was quite detailed. Next, to reduce waste/consumption, the LTWRMS and the 4Rs of the Waste Management Hierarchy were indicated to play an important role in the ROP's waste reduction goals (Region of Peel, 2015a). This was implemented through the cart-based, bi-weekly collection that encouraged residents to manage their waste output and properly sort (Region of Peel, 2015b). Notably, these strategies were implemented as a part of the waste diversion program and did not involve education of residents other than indicating how the program should be used. In fact, educational strategies to reduce consumption were seen to be lacking. Further, it was determined that there was no information on compost use available. Although compost is promoted in various media provided by the ROP, it uses are not mentioned in any of them. It was theorized that compost use is common knowledge and/or that anyone with an interest in compost would already be knowledgeable in how to implement it. Considering the prevalent concerns about metals in the compost, this assumption may be overly optimistic. This knowledge may only be common to gardeners while the general public may not have any experience with compost and need to be educated. It is also important to factor in engaging the ROP's large immigrant population.

\subsection{RECOMMENDATIONS}

A discussion about the past and present strengths and challenges of various waste management strategies determined that landfilling alone was no longer sufficient and although the current diversity of waste diversion strategies shows innovation and forward thinking, there is always room for improvement. One way that the ROP can improve its Green Bin program is to 
look for successful strategies employed by other municipalities in the GTA (e.g., The Regional Municipality of Halton collects Storm Brush on an ongoing basis, the Regional Municipality of York encourages backyard composting, and the City of Toronto offers compost to residents free of charge). The ROP should consider whether the implementation of similar programs would divert a worthwhile amount of organics, and improve the services available to residents. Similarly, the national and provincial standards in other countries and case studies should be examined and compared for their transferability to the ROP's situation. A problem that came up repeatedly is misinformation concerning harmful chemicals and metal in compost. To deal with this concern, a higher level of transparency about the source of organics, the composting process and its composition is recommended. The ROP's compliance with national and provincial regulations should be summarized in plain language by emphasizing the most important points (e.g., The compost is free of biosolids). On a similar note, an organic compost certification option should be considered by the ROP. A number of farmers stated that they could not use the municipal compost as it was not certified organic. The ROP might want to consider providing the option of certified organic compost in order to cater to this demographic. Markedly, the Organic Products Regulations, under the Canada Agricultural Products Act is intended for import, exports and interprovincial trade (Canadian Food Inspection Agency, 2014). Moreover, the "Canada Organic" logo is not intended for the labels of fertilizer supplement products unless already certified by a certification body recognized by the Canada Organic Office, the Canada Food Inspection Agency (CFIA) (2014). Until a technical standard has been developed for certification of fertilizers and supplements, the Organic Products regulations will not be applied (2014). Therefore, the ROP and the OMAFRA need to actively lobby the government and the regulatory bodies to engage in the process of developing technical standards for compost. On the other hand, whether this organic designation is currently technologically possible and economically worthwhile is something the ROP should determine. It should also be taken into account that for agricultural land to be certified organic, the land must be managed as such for 36 months prior to the first harvest (Martin, 2010). Buffer zones of at least 8 metres between organic and nonorganic production are required and these production units cannot alternate between organic and non-organic production (2010). These requirements are already built-in to certified organic farming and will have to be incorporated by the ROP and OMAFRA in their standards. Finally 
and perhaps most importantly, the ROP should lobby the provincial and the federal government to establish a carbon market. The emissions caps and the corresponding carbon credits trading would entice the agricultural sector to evaluate their practices and look for alternatives. In its Green Bin Agriculture Test objectives and outcomes, the ROP has already communicated an interest in determining the value of carbon credits and establishing a trading system. Moreover, other industry sectors may be motivated to participate, as well which will encourage the agriculture sector to take action.

The ROP's Green Bin public awareness campaign provides ample information on how to sort and set-out organic and yard waste through various media; however, there is a notable lack of advertising for compost. It is recommended to add a compost logo, a slogan and some key information on various flyers, fridge magnet schedules and informative brochures that the ROP already sends to residents. This will limit additional expenses and ensure that all residents are aware where and when compost is being sold. It would also be beneficial to announce the availability of compost at the start of the spring season on the home page of the ROP website and on large signs on major traffic arteries in the proximity of CRCs. At the same time, information and demonstration sessions for farmers would garner interest and be a valuable educational tool for the use of the product. Open houses at the PIWMF and at the farms using compost would attest to farmers that compost is a viable soil amendment as well as provide opportunities for farmers to network with municipal representatives and peers.

The in-person interviews have shown farmers who participated in the trials had a more positive outlook about compost use and its potential benefits. Therefore, the use of demonstrations or a free compost to test trial (e.g., 10 tonnes to apply to 1 acre) is recommended as it will allow farmers to see its benefits first hand. In regard to the concerns about transportation costs, for a fee a delivery option may be something the ROP could consider. The option might include a pricing scheme whereas an initial pre-determined number of kilometres would be free and any additional kilometres would be at a pre-set rate per kilometre, special rates or discounts for orders over a certain tonnage. The tiered and volume pricing may appease ROP farmers who were of the opinion that the compost should be free and at the same time attract out of municipality farmers. As the farmland is decreasing and the ROP is looking to expand their market beyond its boundaries, providing compost free of charge to the local community would 
be counterproductive especially when considering that other municipalities compete with the ROP for compost markets. Further, the application costs of compost are off-set by the lower price of compost and concerns over unavailability could be addressed by pre-ordering which is a standard practice in fertilizer sales. Once the compost is delivered to the farm, it can sit in heaps until it is time to apply it. Alternatively, a compost wholesalers/dealers could be supplying compost to their area. Wholesalers would pick-up large quantities of compost from various producers and then sell it to local farmers. Custom spreading, which refers to the spreading of compost is another service they provide at a fee. As almost half of the farmers interviewed had experiences with co-ops or sharing equipment, a joint venture into purchasing a compost spreader is another option. In fact, seven of the sixteen "non-participating" farmers reported having experience with co-ops while nine out of sixteen do not. Some positive aspects of co-ops that came up in conversation were the lower cost to buy equipment stated by seven farmers and the chance to share resources which was noted by three. Negative aspects of co-ops mainly centred around disagreements and other conflicts between farmers which was reported by five of the farmers interviewed.

Considering it was public opposition against unpleasant smells, windblown litter and vermin that lead to the decrease in landfill prominence in the mid-1900s (Tammemagi, 1999, p. 26), it can be said the public perception of refuse as dirty and smelly will be difficult to change. However, in recent decades there has been a notable shift since the start of the environmental movement from consumerism of new products to re-using and repurposing existing resources brought upon the understanding of non-renewable resources. A case in point, the Green Bin has successfully expanded from single residential dwellings to include multi-unit apartments in the collections of organics. The program performed well in reaching the majority of its population and the new diversion rate set in 2015 speaks to this achievement. A question that the ROP might want to investigate next is how well are certain segments of the population complying with organics diversion. Furthermore, examining where and how organics from institutions, responsible for their own collection, are being repurposed is also called for. Overall, it is recommended that a public education campaign be run on preventing food waste as one of the means to reduce waste. The economic evaluation determined that the pricing of compost is favourable and well below the retail price of similar products. Furthermore it appeals to the 
social and environmental responsibility of the consumer and the significance of locally produced compost and locally grown food adds value to the ROP compost. These added value features should be emphasized when selling the product. From the interactions between the Environmental, the Economic and the Social Criteria set out in this paper, it is evident that the theoretical model of Deep Ecology and Strong Sustainability applies to the practical application

of the Green Bin program. All spheres influence one another but in the end they are all limited by the environmental capacity.

\subsection{FURTHER STUDY}

In this section, the potential for further study on the topic of the sustainability of the ROP's Green Bin program will be discussed. This includes a discussion on the limitations of the research conducted and recommendations based on these restrictions to encourage further studies.

\section{$\underline{7.1 \text { Limitations of the Research }}$}

Initially, the Sustainability Criteria were devised in order to provide focus to the study, however there are limitations to this method. Consider the three Criteria and nine accompanying Measures for each Category of sustainability results in a total of 27 questions being pondered. Although, this may seem large, a notable number of topics concerning the sustainability of the program were excluded in the study due to concerns about the broadness of the topic and a lack of depth. For instance, the Environmental Category of Sustainability only integrated climate change as an environmental externality when there is also waste, air emissions and electricity consumption to consider. Further, the choice of topics was limited by the information that is available to the researcher. The electricity or fossil fuel consumption rates of large machinery used by the ROP are not available to the general public and are thus beyond the ability of the researcher to reasonably estimate their emissions. Another consideration is the sheer quantity and variety of topics related to the sustainability of the Green Bin program that could potentially be covered. Unfortunately, only a few select topics could be discussed and documented in the appropriate detail. The topics that were selected however, were pertinent to the investigation due to the focus on organics recycling and the ROP farmer relationship. 
Further complications that arise from the Sustainability Criteria are focused on the weighting system. It is assumed for the purpose of this study that all the Criteria and Measures are of equal importance under the Three Spheres of Sustainability model when in reality, this is untrue. As discussed with Deep Ecology and Strong Sustainability model, sustainability can be seen as three overlapping rings or three rings one inside of the other. The fact that there is no universally agreed upon way to view sustainability makes the importance of the three rings difficult to quantify. Additionally, certain projects may only find specific Categories of Sustainability useful. For example, defenders of a protected area may be interested in environmental sustainability, while a business may be concerned about economic sustainability and a charity may be focused on social sustainability. This study has chosen to incorporate all three Categories of Sustainability in an attempt to provide a more holistic perspective on the Green Bin program.

Finally, the farmer interviews themselves were limited in number and therefore it was necessary to extrapolate the sample onto the ROP farm population. Farmers were generally found to be difficult to recruit due to issues identifying, contacting and securing an interview. This is problematic as the representation of the farmer industry classifications which were important to the study, are difficult to attain in a random sample population. Further, the total number of farmers is small and some of the farmer industries represented between $2-5 \%$ which is in numbers between nine to twenty-two farmers. Unfortunately, this was beyond the control of the researcher. It was also unexpected that farmers would participate in such a variety of farm industries rather than focusing on one. In fact, most of the farmers interviewed did not belong to a single classification but rather multiple. This made generalizing trends for farmers more challenging.

\subsection{Recommendations for Further Study}

Any limitations faced by the initial study can be avoided in further studies by carefully crafting the scope, the methodology and data analysis. Alternatively, a new perspective can be applied to the same issue in order to provide a fresh view point. The initial study was restricted to a certain number of topics due to limited space and concerns about going off topic. Further studies have the ability to research environment, economic or social topics that were overlooked or even investigate subject matters that were already covered but provide greater detail. Overall, 
the addition of more researchers will provide a better rounded knowledge base that is beyond the scope of this individual and improve the study. Alternatively, further studies could also take an aspect of the initial study and expand on it, such as The Three Spheres of Sustainability. It was discussed in the methods section that there are various means to view sustainability including as three rings nested one inside of the other (Meadows et al., 1972) and as three overlapping circles with equal influence (Rodriguez et al., 2002, p. 8). As the latter was explored in this study, the former could be applied in new studies and the results analyzed for comparability.

In regard to the qualitative data collected during the interviews, further studies would either need to interview a greater number of farmers in the ROP or expand the sample population to the Province of Ontario. It was mentioned that the size of farm industries makes it difficult to draw conclusions about farmer groups. In order to ensure that no group is left out without jeopardizing the random sample, the entirety of the ROP would have to be invited to be interviewed. Similarly, the ROP is only a municipality with little data available to be analyzed in comparison to the province of Ontario. Expanding the scope of the study to the province would allow for more interviews to be conducted and for more quantitative data to be produced for comparison purposes. Surveys are also an option as the main issues farmers face with compost use have been identified in this study and can provide insight into appropriate questions. This can be explored through a partnership with the ROP or OMAFRA whereas the surveys would be available to interested farmers on their website. In short, there are a number of options available for further studies whether that involves taking a small portion of the study and expanding on it or discussing something that was missed.

\subsection{CONCLUSION}

In conclusion, the Green Bin program is sustainable when applying the Deep Ecology and Strong Sustainability model. Initially, the Three Spheres of Sustainability were implemented to design the Sustainability Criteria when it was assumed that all three were equal. However, the ROP is a municipality responsible for providing organics collection services regardless if the make a profit. Considering that the economic and social spheres can only expand to the limits of environmental capacity, the environment plays a paramount role. Moreover, the environmental sphere boasts the most positive results of the three which reflects the ROP's focus on diverting 
waste. To begin, the composting of organics is a good diversion strategy and an environmentally conscious solution given that landfilling and trucking away garbage are socially and politically non-viable options for waste management. In the event that compost is not providing sufficient monetary returns for the municipality, the soil amendment could potentially be given away for free or spread over common areas, such as conservation areas and parks while still achieving its goal to enrich the soil. According to 2014 estimated figures, compost did not bring in large revenues for that year. Even in a scenario where the sales would double in 2016 due to the addition of multiple-family dwellings and an overall increase in organics input, the sales would be in the modest $\$ 124,100$ to $\$ 173,740$ range. It is believed that the greatest value of compost is its function as a waste diversion strategy, a soil amendment and a carbon credit earner. As a result, the key to compost sustainability is to continue to diversify by actively pursuing new uses for compost, new partnerships and new markets. 


\section{Appendix A}

Municipal Organic Solid Waste Management and Program Sustainability: A Study of the Region of Peel's Green Bin Program

\section{"Non-Participating" Farmer Interview Questions}

1. Tell me about your farm.

a) What crops do you farm?

b) How many acres of farm land do you work?

c) How long have you been farming?

d) What products do you use to enrich the soil?

e) What is the yield per acre?

f) What are your main concerns as a farmer?

2. Do you feel climate change has an impact on your farming?

a) What kind of impact? Positive? Negative? None?

3. Have you had to take any actions to reduce these impacts? Do you see yourself having to take any actions in the future? Please explain.

a) Have these actions been mainly preventative or reactionary? Do you think these actions will be mainly preventative or reactionary?

4. Have you used compost on your farm before? How did it work out?

5. In your opinion will compost ever be able to completely replace chemical fertilizer?

6. Do you think compost is a viable alternative for large scale farm operations?

7. Are you familiar with the Green Bin Agricultural Test?

a) Would you be interested in participating? Why or why not?

b) What information would you need to make an informed decision?

8. What advantages/disadvantages do you foresee from the Green Bin Agriculture Test?

9. Do you think farmer participation in the Green Bin Agriculture Test would reduce the impact of climate change?

10. Have you had any past experience with farmer co-ops or other similar programs? Please describe them.

11. Do you think there is an advantage/disadvantage to farmer co-ops?

12. Is there anything else you would like to tell me about your experiences as a farmer? 
Municipal Organic Solid Waste Management and Program Sustainability: A Study of the Region of Peel's Green Bin Program

\section{"Participating" Farmer Interview Questions}

1. Tell me about your farm.

a) What do you farm?

b) How many acres of farm land do you own?

c) How long have you been farming?

d) What products do you use to enrich the soil?

e) What is the yield per acre?

f) What are your main concerns as a farmer?

2. Tell me about your decision to participate in the Green Bin Agriculture Test.

a) How did you learn about it?

b) What made you agree to participate?

c) Do you have previous experience with similar programs?

3. Explain your experiences with the Green Bin Agriculture Test and farmer co-ops to date.

4. How has your experience farming changed since entering the co-op?

5. Describe your experience using municipal compost on your farm versus other products.

6. Has your relationship with other farmers changed? Please explain.

7. What are your main concerns as a farmer in the co-op?

8. What have you learned from this experience?

9. Was there anything unexpected that you had to face?

a) How did you overcome any unexpected challenges?

10. Is there anything you would like to tell me about your experiences as a farmer with the co-op?

11. Do you feel climate change has an impact on your farming?

a) What kind of impact? Positive? Negative? None?

12. Have you had to take any actions to reduce these impacts? Do you see yourself having to take any actions in the future? Please explain.

a) Have these actions been mainly preventative or reactionary? Do you think these actions will be mainly preventative or reactionary?

13. Do you think participation in the Green Bin Agriculture Test would reduce the impact of climate change? 


\section{Appendix B}

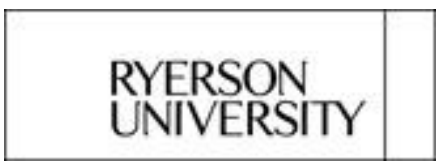

Ryerson University

Consent Agreement

You are being invited to participate in a research study. Please read this consent form so that you understand what your participation will involve. Before you consent to participate, please ask any questions to be sure you understand what your participation will involve.

\section{MUNICIPAL ORGANIC SOLID WASTE MANAGEMENT AND PROGRAM SUSTAINABILITY: A STUDY OF THE REGION OF PEEL'S GREEN BIN PROGRAM}

INVESTIGATORS: This research study is being conducted by Nathalie Zonta under the supervision of Dr. Paul Missios, from the Environmental Applied Science and Management Program at Ryerson University.

If you have any questions or concerns about the research, please feel free to contact Nathalie Zonta at nzonta@ryerson.ca.

PURPOSE OF THE STUDY: The purpose of this study is to assess the environmental, social and economic sustainability of the Region of Peel's Green Bin program. The goal of the interview is to perform an evaluation of the Green Bin program from the perspective of the farmers. This study will:

a) Evaluate current use of compost and future interest in using it.

b) Determine benefits and draw backs of using compost.

c) Assess the impact of current compost marketing strategies.

The recruitment of potential participants for the interview will focus on the key stakeholders in the program: participating farmers in the Green Bin Agriculture Test and non participating farmers. Members of each group will be interviewed with a sample of five from the first group considering the size of the project and ten to fifteen people from the second for worthwhile results.

The results will contribute to a master's thesis.

WHAT PARTICIPATION MEANS: If you volunteer to participate in this study, you will be asked to do the following things: 
Before the Interview

- Agree on a meeting time and location over the phone with the interviewer.

- Read and fill out the consent agreement showing you are willing to participate.

- Tell the interviewer if you are uncomfortable answering any questions.

During the Interview

- Participate in an interview which will occur on one specified day for a time period of one hour maximum.

- Answer 13 questions truthfully and to the best of your abilities. i.e. "Tell me how you decided to participate in the co-op?"

After the Interview

- Confirm if there is any information that was discussed that should be left out and what remains you are comfortable sharing.

- Indicate any additional requirements involving the data and the thesis that need to be met before it is submitted.

Research findings will be made available upon the completion of the thesis upon request.

POTENTIAL BENEFITS: Benefits to the participating farmers include the opportunity to voice their experiences and opinions about the Green Bin program, suggestions for improvement, share challenges faced and to be a part of a progressive, socially and environmentally sound community initiative.

I cannot guarantee, however, that you will receive any benefits from participating in this study.

WHAT ARE THE POTENTIAL RISKS TO YOU AS A PARTICIPANT: There is a risk that anonymized comments may be personally attributable due to the small number of participants in the pilot project and the sample size of the study. Names and personal information (e.g. address, income, etc.) will not be asked for during the interview. The interview questions will only pertain to the size of the farm, the type of crop and yields, and their experiences with the program. Additionally, the interviewer will offer the opportunity for the participants to review their comments made during the interview and edit them.

CONFIDENTIALITY: Names and personal information (e.g. address, income, etc.) will not be asked for during the interview and instead pseudonyms (i.e. Farmer A) will be assigned. The interview questions will only pertain to the size of the farm, the type of crop and yields, and their experiences with the program.

Names will not be asked for in the interview or questionnaires/surveys and will not be used in any publication or report. 
Confidentiality will be obtained by grouping and summarizing the results. Once the data has been collected, it will be analyzed through focused coding which reorganizes the interview transcripts based on relevant themes. The interview responses will be separated based on the different types of respondents to look for themes common to their unique position.

The student researcher Nathalie Zonta will have access to the research data. Transcripts will be typed out on a personal laptop computer. Data will not be shared under any circumstances and will be kept for a period of one year following the thesis defence. Copies of the final thesis paper will be provided to the Ryerson Library, the Region of Peel, the Ontario Ministry of Agriculture, Food and Rural Affairs (OMAFRA) and the Ontario Federation of Agriculture (OFA).

INCENTIVES FOR PARTICIPATION: The participant will not be paid to participate in this study.

COSTS TO PARTICIPATION: There are no costs to participation other than time lost.

VOLUNTARY PARTICIPATION AND WITHDRAWAL: Participation in this study is completely voluntary. You can choose whether to be in this study or not. If any question makes you uncomfortable, you can skip that question. You may stop participating at any time. If you choose to stop participating, you may also choose to not have your data included in the study by the date of January 31st, 2016. Your choice of whether or not to participate will not influence your future relations with Ryerson University or the Region of Peel.

QUESTIONS ABOUT THE STUDY: If you have any questions about the research now, please ask. If you have questions later about the research, you may contact.

Nathalie Zonta, Master's student

Ryerson University, 350 Victoria Street, Toronto, Ontario, Canada M5B 2K3

416.979.5000

nzonta@ryerson.ca

Paul Missios, Thesis Supervisor

Ryerson University, 350 Victoria Street, Toronto, Ontario, Canada M5B 2K3

416.979.5000

pmissios@economics.ryerson.ca

This study has been reviewed by the Ryerson University Research Ethics Board. If you have questions regarding your rights as a participant in this study please contact:

Research Ethics Board

c/o Office of the Vice President, Research and Innovation 
Ryerson University

350 Victoria Street

Toronto, ON M5B 2K3

416-979-5042

rebchair@ryerson.ca 


\section{MUNICIPAL ORGANIC SOLID WASTE MANAGEMENT AND PROGRAM}

SUSTAINABILITY: A STUDY OF THE REGION OF PEEL'S GREEN BIN PROGRAM

\section{CONFIRMATION OF AGREEMENT:}

Your signature below indicates that you have read the information in this agreement and have had a chance to ask any questions you have about the study. Your signature also indicates that you agree to participate in the study and have been told that you can change your mind and withdraw your consent to participate at any time. You have been given a copy of this agreement. You have been told that by signing this consent agreement you are not giving up any of your legal rights.

Name of Participant (please print) 
Appendix C

RYERSON

UNIVERSITY

\section{Are You A Farmer In the Region of Peel?}

Ryerson University Master's student Nathalie Zonta is looking for farmers in the Region of Peel to interview about the potential use of compost on crop yields.

\section{Do You Use Compost on Your Farm?}

\section{Would You Use Compost on Your Farm?}

If you are: an owner/operator/manager of a farm that is located within the Region of Peel, I would like to talk to you about your experiences and opinions on the use of compost in place of chemical fertilizers.

Your participation in this interview would provide valuable input and would be greatly appreciated as it would give credibility and a real life perspective to my Master's thesis paper on the sustainability of compost use.

I am looking forward to hearing from you.

Please email me at nzonta@ ryerson.ca. 


\section{RYERSON}

UNIVERSITY

\section{Are You A Farmer Who Is Participating In the Green Bin Agriculture Test?}

Ryerson University's student Nathalie Zonta is working with the Region of Peel on her Master's Thesis about the sustainability of:

a) diverting household organics from landfills,

b) manufacturing compost and

c) forging partnerships with farmers to use compost instead of chemical fertilizer.

The composting process provides an indirect mitigation strategy to climate change by reducing the amount of Greenhouse Gases released from chemical fertilizers and as such the program might be eligible for carbon credits.

Your opinion is sought about:

your experiences with the project in terms of cost and crop yields comparison, and your thoughts about partnerships and the long-term use of compost as a farming practice.

Your participation in this interview would provide valuable input and would be greatly appreciated as it would give credibility and a real life perspective to my Master's thesis paper on the sustainability of compost use.

I am looking forward to hearing from you.

Please email me at nzonta@ryerson.ca. 


\section{Appendix D}

\section{Telephone Recruitment Script: Participating Farmers}

Hello Mr. or Ms.

My name is Nathalie Zonta and I am a master's student at Ryerson University in the Environmental Applied Sciences and Management Program. I am currently working on my thesis titled: Municipal Organic Solid Waste Management and Program Sustainability: A Study of the Region of Peel's Green Bin Program. Christine Brown from OMAFRA has kindly provided me with a list of participants in the Green Bin Agriculture Test and I believe that she had communicated this to you.

I am investigating the sustainability of the program from the perspective of the farmers involved. I would love to meet with you to talk about your experiences with the program. It would be a maximum of one hour interview at the location and time that is the most convenient for you. I will not be asking for any personal information such as finances and you may withdraw at anytime with no consequences. In that case, the data collected so far would be destroyed. All the information you provide will be strictly confidential and I will be looking for common themes in the data in order to draw conclusions and make recommendations.

I appreciate you taking the time to talk with me. Is there a specific date and time that you would be available to do an interview? 


\section{Email Recruitment Script: Non Participating Farmers}

Hello Mr. or Ms.

My name is Nathalie Zonta and I am a master's student at Ryerson University in the Environmental Applied Sciences and Management Program. I am currently working on my thesis titled: Municipal Organic Solid Waste Management and Program Sustainability: A Study of the Region of Peel's Green Bin Program.

I am investigating the sustainability of the Green Bin program from the perspective of the Region of Peel and the potential farmer participants. I would love to meet with you to talk about your farming experiences. It would be a maximum of a one hour interview at the location and time that is the most convenient for you. I will not be asking for any personal information such as finances and you may withdraw at anytime with no consequences. In that case, the data collected so far would be destroyed. All the information you provide will be strictly confidential. In my analysis, I will be looking for common themes in the data in order to draw conclusions and make recommendations.

If you: are an owner or an operator or a manager of farm land that is located within the Region of Peel, I would appreciate the opportunity to talk with you.

Please respond to this email if you are interested in participating. I appreciate you taking the time to read my letter. If you have any questions or concerns, you can email me at nzonta@ryerson.ca.

Nathalie Zonta

Please find a Ryerson University approved recruitment flyer attached. 


\section{Appendix E}

\section{RYERSONUNIVERSITY}

\section{RESEARCH ETHICS BOARD}

To: Nathalie Zonta

Environmental Applied Science and Management

Re: REB 2015-204: Emissions Trading In Municipal Organics Programs and Farmer Co-op Partnerships: A Case Study of The Region of Peel's Green Bin Agriculture Test.

Date: August 26, 2015

Dear Nathalie Zonta,

The review of your protocol REB File REB 2015-204 is now complete. The project has been approved for a onc ycar period. Pleasc note that before procecding with your project, compliance with other required University approvals/certifications, institutional requirements, or governmental authorizations may be required.

This approval may be extended after one year upon request. Please be advised that if the project is not renewed, approval will expire and no more research involving humans may take place. If this is a funded project, access to research funds may also be affected.

Please note that REB approval policies require that you adhere strictly to the protocol as last reviewed by the REB and that any modifications must be approved by the Board before they can be implemented. Adverse or unexpected events must be reported to the REB as soon as possible with an indication from the Principal Investigator as to how, in the view of the Principal Investigator, these events affect the continuation of the protocol.

Finally, if research subjects are in the care of a health facility, at a school, or other institution or community organization, it is the responsibility of the Principal Investigator to ensure that the ethical guidelines and approvals of those facilities or institutions are obtained and filed with the REB prior to the initiation of any research.

Please quote your REB file number (REB 2015-204) on future correspondence.

Congratulations and best of luck in conducting your research.

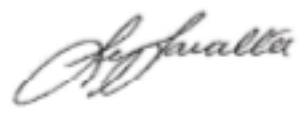

Lynn Lavallée, $\mathrm{Ph} . \mathrm{D}$.

Chair, Research Ethics Board 


\section{Appendix F}

\section{The Composting Process}

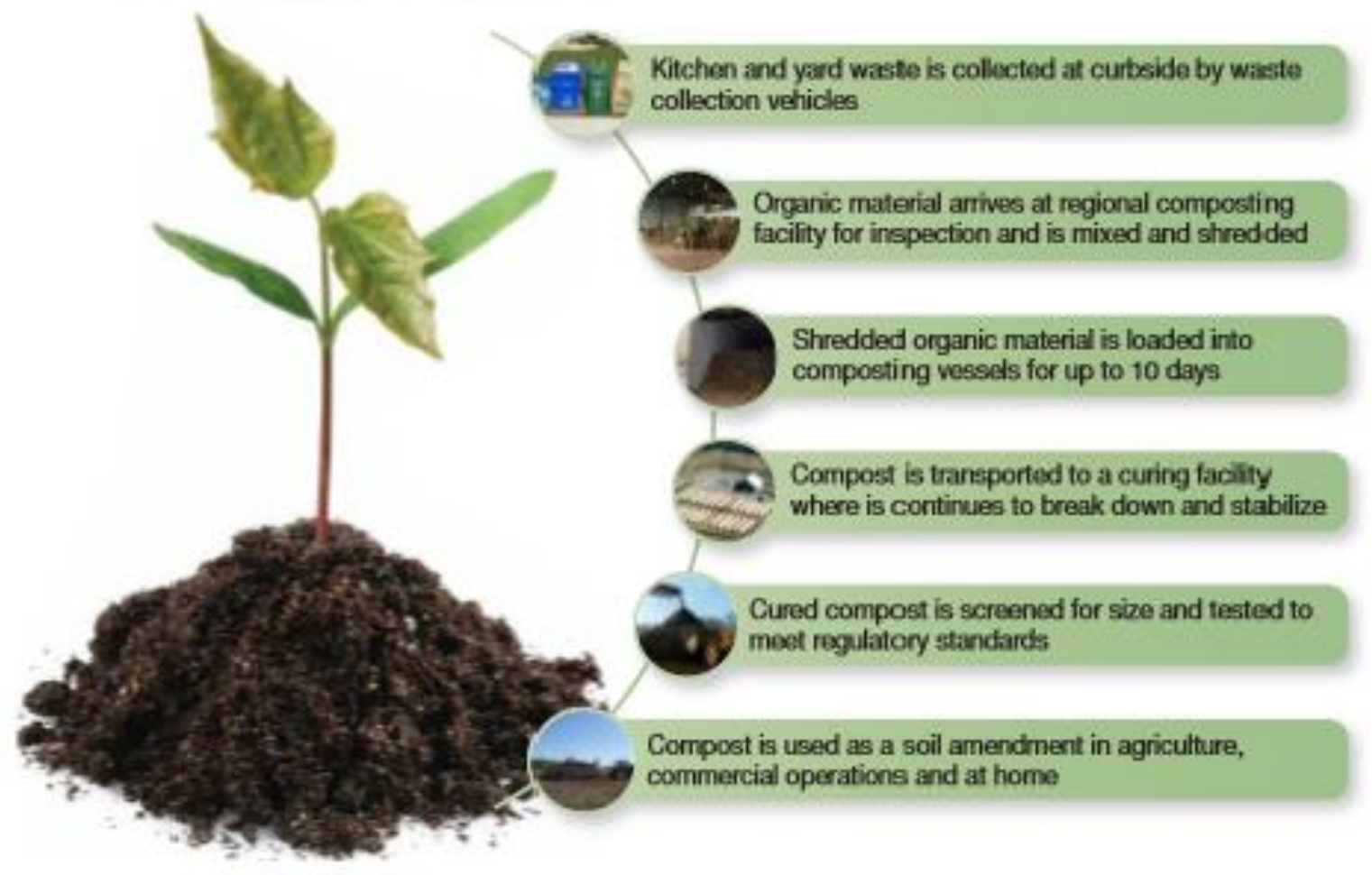

Important Intormation

- Following the application nate prowided with the fiterature wil provant onse from maching the maximum slowable amount of motals in sols

- Faikne io follow the application rate may nessit in an eccumulation of montals in the soil with concentrations that aro boyond scceptable

- Also, if the application thickness is beyond our recommendesions, it mey interfeee with plant root

demblopment by noducing avalabbe crygan in the mociving sol

- Compost should not be usod on sols with olovaled coppor or zine concentrations

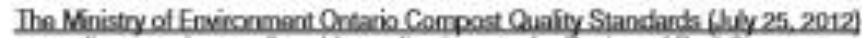
outirnos maximum allowable application rato lor Pegion of Pod Coempos:

Alosidantial appicications: Apply no mone than $2 \mathrm{~kg} g$ por $\mathrm{ft}^{2}$ on an arrual basisi or $1 \mathrm{ckg}$ per ft? for any 5 year poriod

Commercial or Agricultural appoficafions: Apply less then 22.36 tonnes per hectare per year cr a total equivalert of 52 tornes por hectars over ary 5 your period should the application not occur on an annual basis 


\section{Reference List}

Biala, J. (2011, February). Short report: The benefits of using compost for mitigating climate change. Retrieved from http://www.epa.nsw.gov.au/resources/waste/110171-compostclimate-change.pdf

Black, A. W. (2004). The quest for sustainable, healthy communities. Australian Journal of Environmental Education, 21(1), 1-11.

Boldrin, A., Andersen, J. K., Moller, J., Christensen, T. H., \& and Favoino, E. (2009). Composting and compost utilization: accounting of greenhouse gases and global warming contributions. Waste Management \& Research, 27, 800-812.

Boughton, N. (Eds.). (2015). October 8, 2015 Special Regional Council Minutes. Brampton, ON. http://www.peelregion.ca/council/council_minutes/2010s/2015/srcmin20151008.htm\#rep orts

Brethour, C., \& Klimas, M. (2008). Emissions Trading in Agriculture: A Canadian Perspective. Guelph: George Morris Centre. 
Brown, C. (2014). Cities Feed Farm Soils: Green Bin-derived Compost Agriculture Trials [PDF Document]. Retrieved from http://www.compost.org/English/PDF/WRW_2014/ON/C_Brown_OMAF_Cities_Feed_ Farm_Soils.pdf

Butters, M. (2003). Emissions Trading Primer. http://books2.scholarsportal.info.ezproxy.lib.ryerson.ca/viewdoc.html?id=/ebooks/ebooks 0/gibson_cppc/2009-12-01/2/202511\#tabview=tab0

Campbell, S. (1975). Let it Rot: The Gardener's Guide to Composting. Pownal: Story Communications, Inc.

Canada Food Inspection Agency. (2014). T-4-120 - Regulation of Compost under the Fertilizers Act and Regulations. Retrieved from http://www.inspection.gc.ca/plants/fertilizers/tradememoranda/t-4-120/eng/1307910204607/1307910352783

Canadian Council of Ministers of Environment. (2014a). State of Waste Management in Canada. Retrieved from http://www.ccme.ca/files/Resources/waste/wst_mgmt/State_Waste_Mgmt_in_Canada\%2 0April\%202015\%20revised.pdf

Canadian Council of Ministers of Environment. (2014b). Current Priorities: Waste. Retrieved from http://www.ccme.ca/en/current_priorities/waste/index.html 
Canadian Council of Ministers of Environment. (2014c). Current Priorities: Extended Producer Responsibility. Retrieved from http://www.ccme.ca/en/current_priorities/waste/epr.html

Canadian Council of Ministers of the Environment (2005). Guidelines for Compost Quality. Retrieved from http://www.ccme.ca/files/Resources/waste/compost_quality/compostgdlns_1340_e.pdf

City of Brampton (2015). Visitors. Retrieved from http://www.brampton.ca/EN/Arts-CultureTourism/Tourism-Brampton/Visitors/Pages/welcome.aspx

City of Toronto. (2016). Organics (Green Bin) Frequently Asked Questions. Retrieved from http://www1.toronto.ca/wps/portal/contentonly?vgnextoid=2117ca58ea332410VgnVCM 10000071d60f89RCRD\&vgnextchannel=ceed433112b02410VgnVCM10000071d60f89 RCRD

Colantonio, A. (2007). Social Sustainability: An Exploratory Analysis of its Definition, Assessment Methods, Metrics and Tools. Measuring Social Sustainability: Best Practice from Urban Renewal in the EU, 2007/01: EIBURS Working Paper Series. Oxford: Oxford Brookers University.

Compost Council of Canada. (2010a). Compost Council of Canada. Retrieved from http://www.compost.org/English/ENGLISH_INDEX.htm 
Compost Council of Canada. (2010b). 25 Questions and Answers about Composting. Retrieved from http://www.compost.org/English/qna.html\#section23

Compost Quality Alliance. (n.d.). The Compost Quality Alliance. Retrieved from http://www.compost.org/CQA-En.html

Conrad. L. (2012). Cities Feed Farm Soils: Moving Compost Into Agriculture [PDF document]. Retrieved from http://www.compost.org/conf2012/Closing_Plenary/Cities_Feed_Farm_Soils_L_Conrad_ Region_of_Peel.pdf

Cooperband, L. (2002). The Art and Science of Composting: A Resource For Farmers and Compost Producers. Retrieved from http://www.cias.wisc.edu/wpcontent/uploads/2008/07/artofcompost.pdf

Criscione, P. (2015, June 18). Peel Region to Receive Grant Money For Compost Research. Brampton Guardian. Retrieved from http://www.bramptonguardian.com/newsstory/5683915-peel-region-to-receive-grant-money-for-compost-research/

Dearden, P., \& Mitchell, B. (2009). Environmental Change and Challenge. Toronto: Oxford University Press. 
Environment Canada. (2013, October). Canada's Emission Trends. Retrieved from http://www.ec.gc.ca/ges-ghg/985F05FB-4744-4269-8C1A-D443F8A86814/1001Canada's\%20Emissions\%20Trends\%202013_e.pdf

Favoino, E., \& Hogg, D. (2008). The potential role of compost in reducing greenhouse gases. Waste Management \& Research, 26, 61-69.

Federation of Canadian Municipalities (2014). Green Municipal Fund: What We Fund. Retrieved From http://www.fcm.ca/home/programs/green-municipal-fund/what-we-fund.htm

Ferrara, I., \& Missios, P. (2005). Recycling and Waste Diversion Effectiveness: Evidence from Canada. Environmental \& Resource Economics, 30, 221-238.

Gilbert, R., Stevenson, D., Girardet, H., \& Stren, R. (1996). Making Cities Work: The Role of Local Authorities in the Urban Environment. London: Earthscan Publications Ltd.

Goetz, J. C., De Castro, M. M., Taylor, G., \& Haugen-Kozyra, K. (2009). Development of Carbon Emissions Trading in Canada. Alberta Law Reviews, 46(2), 377-425.

Government of Canada. (2015). Facts on Climate Change. Retrieved from http://www.climatechange.gc.ca/default.asp?lang=En\&n=F2DB1FBE-1 
Home Depot. (2016). Premier Mushroom Compost. Retrieved from https://www.homedepot.ca/en/home/p.premier--mushroom-compost.1000670402.html

Koford, B. C., Blomquist, G. C., Hardesty, D. M., \& Troske, K. R. (2012). Estimating Consumer Willingness to Supply and Willingness to Pay for Curbside Recycling. Land Economics, 88(4), 745-763.

Lamaadar, A. (2011). Opportunities for Carbon Credits: Compost. Available from http://www.scribd.com/doc/55039107/Compost-and-Carbon-Credits-North-America

Lee, N. (2015a). Approach to Developing a Work Plan to: Achieve Peel's New 75\% 3Rs Target \& Manage the Remaining 25\% [PDF Document]. Retrieved from http://www.peelregion.ca/council/agendas/2015/2015-11-19-wmsac-agenda.pdf

Lee, N. (2015b). Infrastructure Development Plan - Use of Anaerobic Digestion for Green Bin Organics [PDF Document]. Retrieved from http://www.peelregion.ca/council/agendas/2015/2015-06-18-wmsac-agenda.pdf

Lowe's. (2016). Scotts 20lb Pro Blends ${ }^{\mathrm{TM}}$ 3-in-1 Pre-Mixed Topsoil. Retrieved from https://www.lowes.ca/potting-mix/scotts-20-lb-pro-blendstrade-3-in-1-pre-mixedtopsoil_g2461392.html?searchTerm=top-soil 
Martin, H. (2010, January). Factsheet: Transition to Organic Crop Production. Retrieved from http://www.omafra.gov.on.ca/english/crops/facts/10-001.htm

Martin, H. (2005, March). Fact Sheet: Agricultural Composting Basics. Retrieved from http://www.omafra.gov.on.ca/english/engineer/facts/05-023.htm

Meadows, D. H., Meadows, D. L., Randers, J., \& Behrens, W. W. (1972). Limits to Growth. New York: Universe Books.

Middlesex County Council. (2014). Greenbin-derived Compost Trials at Strathmere Lodge site [PDF Document]. Retrieved from https://www.middlesex.ca/council/2014/april/22/5\%20a\%20-\%20CC\%20$\% 20$ April $\% 2022 \% 20-$ \%20Greenbin\%20summary\%20Middlesex\%20county\%20council\%20April\%202014.pdf

Ministry of the Environment and Climate Change. (2014). Ontario's Climate Change Update 2014. Retrieved from https://dr6j45jk9xcmk.cloudfront.net/documents/3618/climatechange-report-2014.pdf

Ministry of the Environment (2012). An Update of Ontario's Compost Guideline and Regulatory Framework. Retrieved from http://www.ebr.gov.on.ca/ERS-WEBExternal/displaynoticecontent.do?noticeId=MTA2NTgz\&statusId=MTcwNjE5\&languag $\mathrm{e}=\mathrm{en}$ 
Mississauga (2015). About Mississauga. Retrieved from http://www.mississauga.ca/portal/discover/aboutmississauga

Moldan, B., Janoušková, S., \& Hák, T. (2012). How to understand and measure environmental sustainability: indicators and targets. Ecological Indicators, 17, 4-13.

Morrow, A. (2015, April 13). Cap and Trade Explained: What Ontario's Shift on Emissions Will Mean. Globe and Mail. Retrieved from http://www.theglobeandmail.com/news/politics/cap-and-trade-explained-what-ontariosshift-on-emissions-will-mean/article23895285/

Neal, H. A., \& Schubel, J. R. (1987). Solid Waste Management and the Environment: The Mounting Garbage and Trash Crisis. Toronto: Prentice-Hall Canada Inc.

Ontario Federation of Agriculture. (2016). Calendar of Events. Retrieved from http://www.ofa.on.ca/get-involved/calendar-events.aspx

Ontario Ministry of Agriculture, Food and Rural Affairs (OMAFRA). (2014). Census. Retrieved from http://www.omafra.gov.on.ca/english/stats/census/index.html

Ontario Ministry of the Environment (2012a, July 25). Ontario Compost Quality Standards. Retrieved from https://dr6j45jk9xcmk.cloudfront.net/documents/1234/104-ontariocompost-quality-standards-en.pdf 
Ontario Ministry of the Environment (2012b, July 25). Guideline for the Production of Compost in Ontario. Retrieved from https://dr6j45jk9xcmk.cloudfront.net/documents/1230/101production-of-compost-en.pdf

Opp, S. M., \& Saunders, K. L. (2012). Pillar Talk: Local Sustainability Initiatives and Policies in the United States - Finding Evidence of the "Three E's": Economic Development, Environmental Protection, and Social Equity. Urban Affairs Review, 49(5), 678-717.

Partanen, P., Hultman, J., Paulin, L., Auvinen, P., \& Romantschuk, M. (2010). Bacterial Diversity at Different Stages of the Composting Process. BMC Microbiology, 10(94), 1471-2180.

Peel Data Centre (2013). 2011 Census Bulletin. Retrieved from https://www.peelregion.ca/planning-maps/Agriculture_Bulletin_Web.pdf

Peel Data Centre. (2007). BULLETIN: 2006 Census of Agriculture. Retrieved from https://www.peelregion.ca/planning/bulletins/2006/2006Cen-Agriculture_Bulletin.pdf

Peel Data Centre. (n.d.). Population 1971 to 2011: Peel Region and Area Municipalities. Retrieved from https://www.peelregion.ca/planning/pdc/data/census/population-19712006.htm 
Pollock, A. (2006). The Role of Energy from Waste in the Region of Peel [PDF Document]. Retrieved from https://www.rco.on.ca/uploads/File/events/energyfromwaste/RC_EventsEFW-Peel.pdf

Poutiainen, C., Berrang-Ford, L., Ford, J., \& Heymann, J. (2013). Civil society organizations and adaptation to the health effects of climate change in Canada. Public Health, 127, 403409.

Region of Peel (2015a). Waste Management Overview. Retrieved from https://www.peelregion.ca/waste/waste-management-overview

Region of Peel (2015b). Waste Collection in the Region of Peel is Changing to Cart-Based, BiWeekly Collection. Retrieved from http://prd.app1.peelregion.ca/cart-confirmation/

Region of Peel (2015c). Compost. Retrieved from http://www.peelregion.ca/waste/compost\#compost_buycompost

Region of Peel (2015d). Peel Community Recycling Centres (CRCs). Retrieved from http://www.peelregion.ca/waste/community-recycling-centres\#crc_hazardous 
Region of Peel (2015e). Government of Canada and FCM Support Peel's Exploration of Agricultural Market for Household Compost. Retrieved from http://www.peelregion.ca/news/archiveitem.asp?year=2015\&month=5\&day=18\&file=20 15518.xml

Region of Peel (2015f). Region of Peel. Retrieved from https://www.peelregion.ca/

Region of Peel. (2015g). Waste Management. Retrieved from https://www.peelregion.ca/waste/

Region of Peel. (2015h). Organics. Retrieved from https://www.peelregion.ca/waste/green-binorganics\#organics-acceptable

Region of Peel. (2015i). Yard Waste. Retrieved from https://www.peelregion.ca/waste/yardwaste\#yardwaste-acceptable

Region of Peel (2015j). Garbage. Retrieved from http://www.region.peel.on.ca/waste/garbage

Region of Peel. (n.d. a). Region of Peel By-Laws. Retrieved from https://www.peelregion.ca/council/bylaws/archive.htm

Region of Peel (n.d. b). Peel Region Official Plan. Retrieved from https://www.peelregion.ca/planning/officialplan/prov-drivers.htm\#grow 
Rodriguez, S. I., Roman, M. S., Sturhahn, S. C., \& Terry, E. H. (2002, April). Sustainability Assessment and Reporting for the University of Michigan's Ann Arbor Campus. Retrieved from http://css.snre.umich.edu/css_doc/CSS02-04.pdf

Saha, D. (2009). Empirical research on local government sustainability efforts in the USA: Gaps in the current literature. Local Environment, 14(1), 17-30.

Sawell, S. E., Hetherington, S. A., \& Chandler, A. J. (1997). An Overview of Municipal Solid Waste Management in Canada. Waste Management, 16(5), 351-359.

Smith, A., Brown, K., Ogilvie, S., Rushton, K., \& Bates, J. (2001). Waste Management Options and Climate Change. Final report to the European Commission, DG Environment. AEA Technology. Office for Official Publications of the European Communities, Luxembourg.

Statistics Canada. (2015). Census Profile [Data File]. Retrieved from http://www12.statcan.gc.ca/census-recensement/2011/dp$\mathrm{pd} /$ prof $/$ details/page.cfm?Lang=E $\&$ Geo $1=$ CD $\&$ Code $1=3521 \& G e o 2=P R \&$ Code $2=35 \& D a$ ta $=$ Count $\&$ SearchType $=$ Begins $\&$ SearchPR $=01 \& B 1=$ All

Statistics Canada. (2008). Total farm area, land tenure and land in crops, by province (Census of Agriculture, 1986 to 2006) (Ontario). Retrieved from http://www.statcan.gc.ca/tablestableaux/sum-som/101/cst01/agrc25g-eng.htm 
Stone, R. (1976). Sanitary Landfill. In D. G. Wilson (Eds.), Handbook of Solid Waste Management (pp. 226-263). New York: Van Nostrand Reinhold Company.

Tammemagi, H. (1999). The Waste Crisis: Landfills, Incinerators, and the Search for a Sustainable Future. New York: Oxford Press.

Tchobanoglous, G., Theisen, H., and Vigil, S. (1993). Integrated Solid Waste Management: Engineering Principles and Management Issues. New York: Irwin McGraw-Hill.

The Regional Municipality of Halton (2014). Waste Diversion Report (tonnes) 2014. Retrieved from http://www.halton.ca/cms/One.aspx?portalId=8310\&pageId=30883

The Regional Municipality of Peel. (2015). BY-LAW NUMBER 35-2015. Retrieved from http://www.peelregion.ca/council/bylaws/2010s/2015/by35-2015.htm

The Regional Municipality of York. (2016). Compost and Green Bin. Retrieved from http://www.york.ca/wps/portal/yorkhome/!ut/p/a1/04_Sj9CPykssy0xPLMnMz0vMAfGjz OKNjEzMPAydDbwMPPwtDDzdzANMXSw8DA28jYAKIoEKDHAARwNCsP1o8BK8JhQkBthkO6oqAgA8oC4Gg!!/d15/d5/L2dBISEvZ0FBIS9nQSEh/\#.VvGQYke W3IU

Town of Caledon (n.d.). About Caledon. Retrieved from http://www.caledon.ca/en/explore/aboutcaledon.asp 
Walmart. (2016). Premier Potting Soil 18L. Retrieved from http://www.walmart.ca/en/ip/premier-potting-soil-181/6000190511841

World Commission on Environment and Development. (1987, August 4). Our Common Future. Retrieved from http://www.un-documents.net/our-common-future.pdf 